\title{
QNREL
}
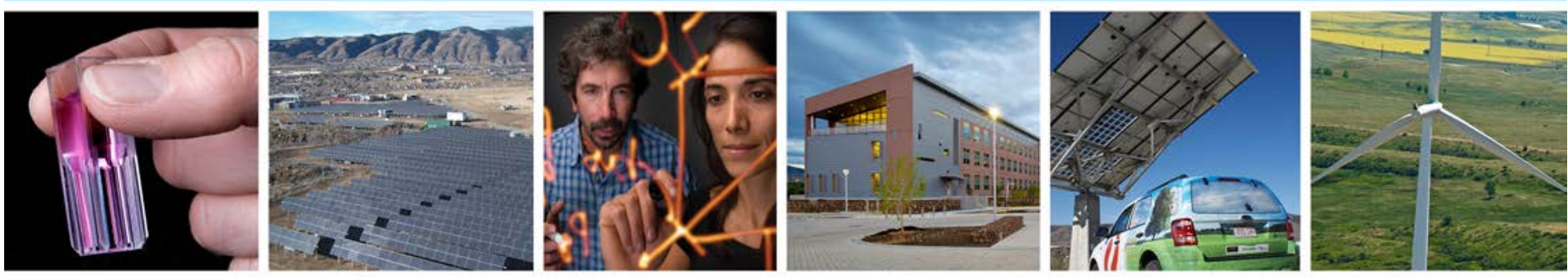

\section{Opportunities and Challenges for Solar Minigrid Development in Rural India}

N. Thirumurthy, L. Harrington, and D. Martin National Renewable Energy Laboratory

L. Thomas

Global Business Inroads

J. Takpa and R. Gergan

Ladakh Renewable Energy Development Agency

NREL is a national laboratory of the U.S. Department of Energy, Office of Energy Efficiency \& Renewable Energy, operated by the Alliance for Sustainable Energy, LLC.

Technical Report

NREL/TP-7A40-55562

September 2012 


\section{Opportunities and Challenges for Solar Minigrid Development in Rural India}

Nisha Thirumurthy, Laura Harrington, and Daniel Martin National Renewable Energy Laboratory

Leena Thomas

Global Business Inroads

Jigmet Takpa and Reuben Gergan

Ladakh Renewable Energy Development Agency

Prepared under Task No(s). IGIN.1106

NREL is a national laboratory of the U.S. Department of Energy, Office of Energy Efficiency \& Renewable Energy, operated by the Alliance for Sustainable Energy, LLC.

National Renewable Energy Laboratory 15013 Denver West Parkway Golden, Colorado 80401 303-275-3000 • www.nrel.gov
Technical Report

NREL/TP-7A40-55562

September 2012 


\section{NOTICE}

This report was prepared as an account of work sponsored by an agency of the United States government. Neither the United States government nor any agency thereof, nor any of their employees, makes any warranty, express or implied, or assumes any legal liability or responsibility for the accuracy, completeness, or usefulness of any information, apparatus, product, or process disclosed, or represents that its use would not infringe privately owned rights. Reference herein to any specific commercial product, process, or service by trade name, trademark, manufacturer, or otherwise does not necessarily constitute or imply its endorsement, recommendation, or favoring by the United States government or any agency thereof. The views and opinions of authors expressed herein do not necessarily state or reflect those of the United States government or any agency thereof.

Available electronically at http://www.osti.gov/bridge

Available for a processing fee to U.S. Department of Energy and its contractors, in paper, from:

U.S. Department of Energy

Office of Scientific and Technical Information

P.O. Box 62

Oak Ridge, TN 37831-0062

phone: 865.576 .8401

fax: 865.576 .5728

email: mailto:reports@adonis.osti.gov

Available for sale to the public, in paper, from:

U.S. Department of Commerce

National Technical Information Service

5285 Port Royal Road

Springfield, VA 22161

phone: 800.553 .6847

fax: 703.605.6900

email: orders@ntis.fedworld.gov

online ordering: http://www.ntis.gov/help/ordermethods.aspx

Cover Photos: (left to right) PIX 16416, PIX 17423, PIX 16560, PIX 17613, PIX 17436, PIX 17721

Printed on paper containing at least $50 \%$ wastepaper, including $10 \%$ post consumer waste. 


\section{Acknowledgments}

The U.S. Department of Energy's (DOE's) National Renewable Energy Laboratory (NREL) would like to thank DOE's Office of Energy Efficiency and Renewable Energy for its support and guidance in developing this report.

NREL would also like to thank the Indian Ministry of New and Renewable Energy, the Ladakh Renewable Energy Development Agency, and the Ladakh Autonomous Hill Development Council for providing the energy data necessary to perform a robust analysis.

NREL would also like to acknowledge the contributions of renewable energy project developers, including Tata BP Solar, Orb Energy, Wipro Eco Energy, Eversun, Kotak Urja, Husk Power, Acumen, and Sgurr Energy for discussing their experience in developing solar minigrid projects. 


\title{
Acronyms
}

\author{
AC alternating current \\ CFL compact fluorescent light \\ DC direct current \\ DOE Department of Energy \\ DPR detailed project reports \\ FI financial institution \\ FIMMDA Fixed Income Money Market and Derivatives Association \\ GW gigawatt \\ HLS home lighting system \\ HSD high speed diesel \\ IREDA Indian Renewable Energy Development Agency \\ INR Indian rupee \\ IRR internal rate of return \\ JKPDC Jammu and Kashmir Power Development Corporation \\ JKPDD Jammu and Kashmir Power Development Department \\ JNNSM Jawaharlal Nehru National Solar Mission \\ kVa kilovolt-ampere \\ kW kilowatt \\ kWh kilowatt-hour \\ kWp kilowatt-peak \\ KVA kilovolt-ampere \\ LAHDC Ladakh Autonomous Hill Development Council \\ LeDG Ladakh Ecological Development Group
}


LMLA low-maintenance lead acid

LREDA Ladakh Renewable Energy Development Agency

MAT Minimum Alternative Tax

MFI microfinance institution

MNRE Ministry of New and Renewable Energy

MOU memorandum of understanding

MoP Ministry of Power

MPNG Ministry of Petroleum and Natural Gas

mWh megawatt-hour

NABARD National Bank for Agricultural and Rural Development

NHB National Housing Bank

NREL National Renewable Energy Laboratory

O\&M operations and maintenance

NOC no objection certificate

PAC project approval committee

PEEST political, economic, environmental, social, and technological

PV photovoltaic

REC Rural Electrification Corporation

RESCo renewable energy service company

RFP request for proposal

RGGVY Rajiv Gandhi Grameen Vikas Yojana

RReDC Renewable Resource Data Center

SIDBI Small Industries Development Bank of India

SNA state nodal agency 
SPV solar photovoltaic

T\&D transmission and distribution

VEC Village Electrification Committee 


\section{Executive Summary}

The goal of this report is to inform investors about the potential of solar minigrid ${ }^{1}$ technologies to serve India's rural market. India, a rapidly emerging economy with the world's second largest population, is facing a surging energy demand. A large portion of India's rural population, which represents $60 \%$ of the total population, does not have access to reliable electricity or has limited access and relies heavily on fuels such as wood, diesel, and kerosene to fulfill energy needs. Using the most recent available expenditure data, it is estimated that India's rural consumers currently spend US $\$ 4.86$ billion (INR 243 billion $^{2}$ ) per year on energy. Because of the linkages between reliable electricity supply, gross domestic product growth, and living standards, the Indian government is accelerating the deployment of electricity to India's rural population.

In January 2010, India's Ministry of New and Renewable Energy (MNRE) under the Jawaharlal Nehru National Solar Mission (JNNSM) announced the goal of deploying 20 gigawatts (GW) of grid-connected solar power and $2 \mathrm{GW}$ of off-grid solar by 2022. Their objective is to invest in India's vast solar resources by deploying solar energy on a broad scale and extending modern power services to millions. Specifically, the JNNSM in Phase I of the mission has set the goal of implementing $1 \mathrm{GW}$ of grid-connected solar and 200 megawatts (MW) of off-grid solar power (rural village electrification) by March 2013. By providing many incentives for renewable energy projects, including capital subsidies of up to $90 \%$, tax holidays, and low-interest loans, the government is hoping to spur clean energy development in key areas.

India's electricity demand is expected to increase from 900 billion kilowatt-hours $(\mathrm{kWh})$ to 1,400 billion kWh by March 2017. To meet this demand, India's power sector overall will need an investment of US $\$ 300$ billion to US $\$ 400$ billion during the five-year economic plan that started April 2012 and ends March 2017 to meet its generation targets. ${ }^{3}$ MNRE's target of installing $1,100 \mathrm{MW}$ of solar minigrid capacity in the next five years ${ }^{4}$ will require public and private sector investments of roughly \$US4.4 billion. ${ }^{5}$

\section{Minigrid Technical Solution}

NREL worked with electricity capacity and demand data supplied by the Ladakh Renewable Energy Development Agency (LREDA) from the Leh District in Ladakh, India, to develop a technical approach for solar minigrid development. The current installed capacity in the Leh District is 23.14 MW, of which diesel makes up 15.2 MW and hydro and solar comprise 7.8 MW and 140 kilowatts $(\mathrm{kW})$, respectively. According to LREDA, the power demand of the Leh District was $58.53 \mathrm{MW}$ in 2005 and grew at an average rate of 7\% a year to $87 \mathrm{MW}$ in 2011.

\footnotetext{
${ }^{1}$ In this report, a minigrid is defined as a solar PV plant with a localized distribution network to a single village, or a cluster of villages, providing alternating current (AC). A microgrid is smaller than a minigrid and provides direct current (DC). This is consistent with how the Indian government and industry distinguish between the two.

${ }^{2}$ Exchange rate assumed INR 50 to US\$1.

3 http://mnre.gov.in/file-manager/UserFiles/strategic plan_mnre 2011 17.pdf

4 Ibid.

${ }^{5}$ Estimated market potential of US\$4.4 billion is based on calculations considering 1,100 MW government target by 2017 and with a cost of INR 200 million/MW (US\$4 million/MW). Baseline cost was taken from a SunEdison project where a 15-kW minigrid was implemented at INR 3 million (US\$60,000/MW).
} 
Assuming the same growth rate for subsequent years, the current demand for energy is in the range of 93.6 MW and is expected to grow to $107 \mathrm{MW}$ by 2014.

Solar minigrids will have the capability of providing much needed power throughout the year. Based on the NREL-developed, simulated solar insolation data for the city of Leh, a 250-kW solar photovoltaic (PV) system can produce $427,737 \mathrm{kWh}$ over a 12 -month period. The main reason for selecting a $250-\mathrm{kW}$ system for the technical configuration is because the JNNSM subsidy for minigrids is capped at that level. Based on solar energy output, a $60-\mathrm{kW}$ energy storage system should be sized for 1.2 megawatt-hours (MWh) of storage and a 200-kW power rating. The battery will provide $1,200 \mathrm{kWh}$ of energy at night, and the PV will produce in excess of $1,200 \mathrm{kWh}$ of energy during the day to charge the battery.

In order to meet all the demand, the Leh District would need to build between 180 and 301 systems rated at $250-\mathrm{kW}$ each.

\section{Business Case and Project Economics}

The objective of the business case analysis is to show at a general level the economics of building 250-kW solar minigrids in the Leh District and in other regions of India where subsidies may not be as high. There are two different analyses presented. The first, which contains four scenarios, is to determine the project economics or the cost to developers in implementing solar minigrids with an assumed internal rate of return of $20 \%$ based on different regional incentive schemes offered under JNNSM. The second analysis determines the cost to users of electricity from the minigrid and examines how that compares to the cost of diesel and hydro generation. The costs presented are rough estimates and will require further analysis and verification to ensure accuracy.

According to our analysis, the cost of power ranges from Rs. $6.3 / \mathrm{kWh}$ (US\$0.126) to Rs. 9/kWh (US\$0.18). At these rates, solar power is a cheaper alternative to diesel in all four scenarios and in some instances might be a cheaper alternative to hydro as well. The cost of diesel power ranges from Rs. $12 / \mathrm{kWh}$ to Rs. $67 / \mathrm{kWh}$, and hydro is expected to be in the range of Rs. 3 to Rs. $10 / \mathrm{kWh}$, depending on the size of the hydro project.

\section{Challenges and Recommendations}

An assessment of the macro-environment elements - including political, economic, environmental, social, and technological—identified factors that may impact India's energy development initiatives. One of the key challenges is aligning national road maps, policies, and programs seamlessly to achieve meaningful levels of solar minigrid deployment in rural areas. This is most effective when combined with coordination and consistency from the institutional level to the regional and local level, which will accelerate deployment of energy initiatives.

While expanded reliance on renewable technologies helps mitigate climate change risks, the move to a power system-based model on local energy technologies requires the development of knowledge, skills, and operating procedures that may not be widespread in isolated rural communities. Assistance or training may be needed from regional entities or other experts to increase local capacity to develop the necessary regulatory framework and programs to enact and implement the policy initiatives. 
Addressing the following four strategies has the potential to catalyze minigrid development in India:

1. Identifying plots of land for project development, leading to creation of a "land bank" that can help remove the information gap on where to optimally locate projects

2. Streamlining the project development process to help ensure checks and balances within the system and to foster delivery of electricity in a reliable, cost-effective, and safe manner

3. Ensuring project bankability through off-take agreements and bundling villages for energy services to increase customer base, along with offering training and incentives that empower village entrepreneurs to increase long-term revenue prospects for energy service providers and investors

4. Implementing several minigrid pilot projects across India to assist in the development of a turnkey systems approach for a replicable technical model for minigrid deployment 


\section{Table of Contents}

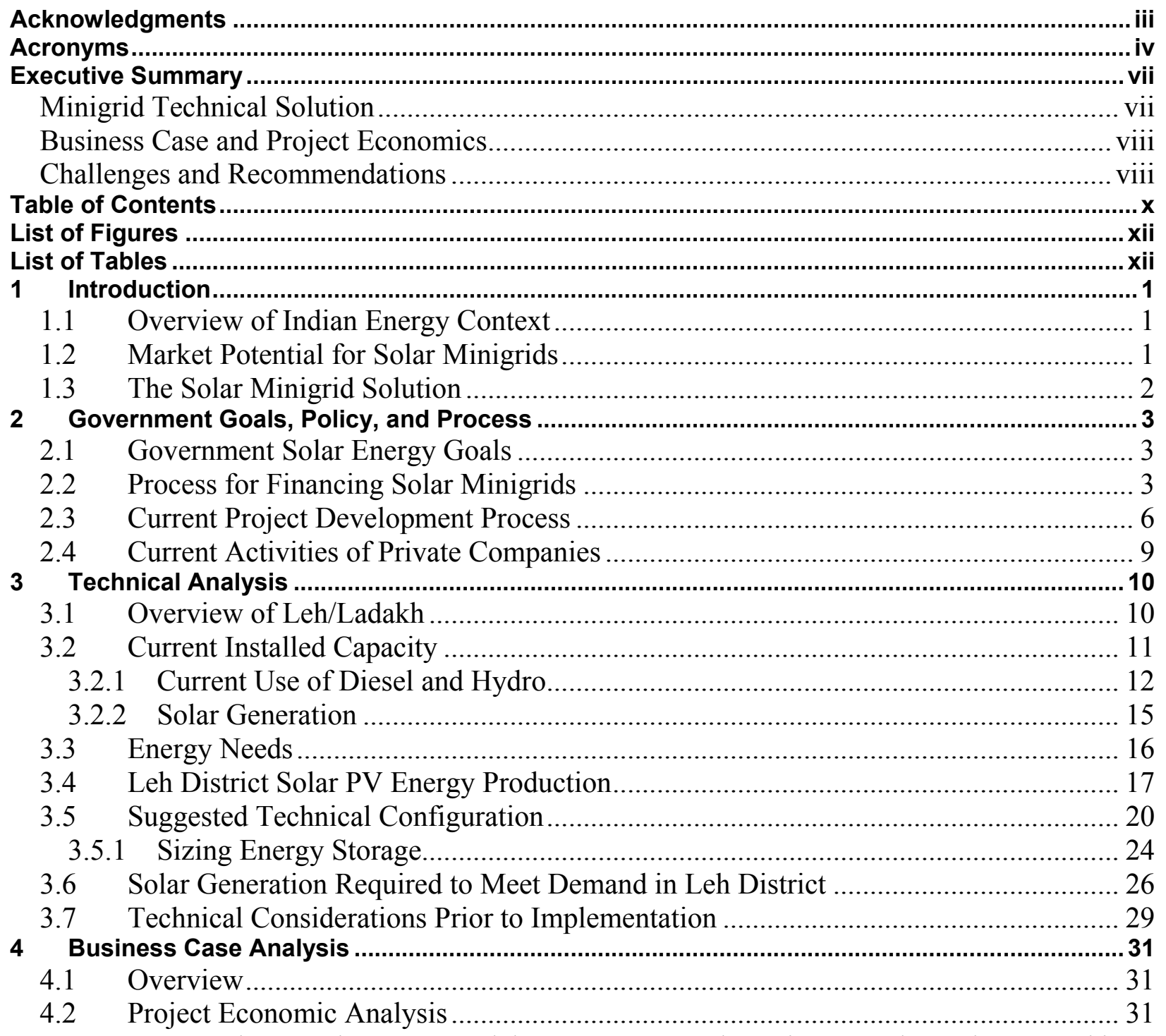

4.2.1 Scenarios 1 and 2: State Nodal Agency as Developer in Normal Rural Area and in Remote Locations ...................................................................................................... 31

4.2.2 Scenarios 3 and 4: Private Developer Perspective in Rural India and Remote

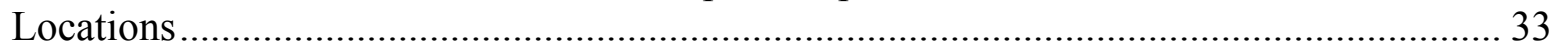

4.3 Customer Rate Comparison ................................................................................ 38

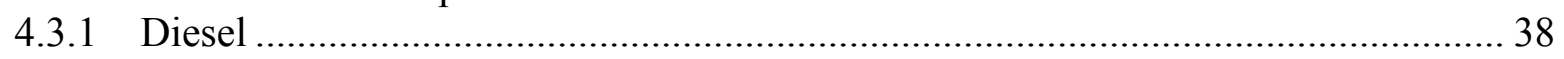

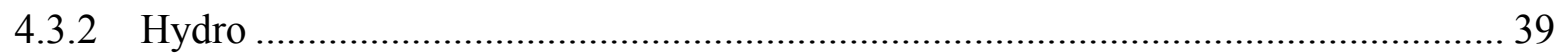

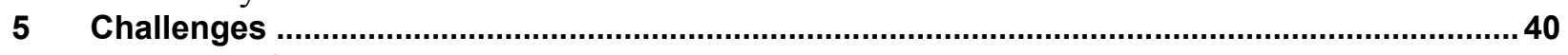

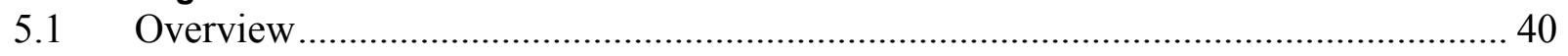

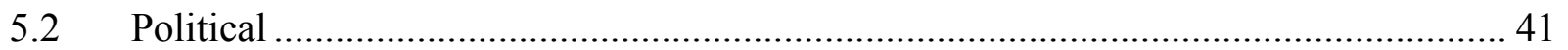

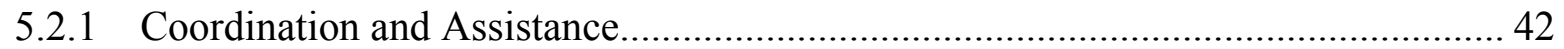

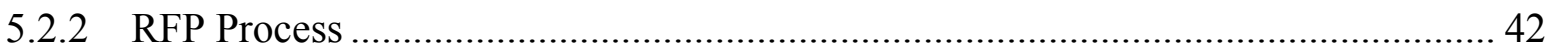

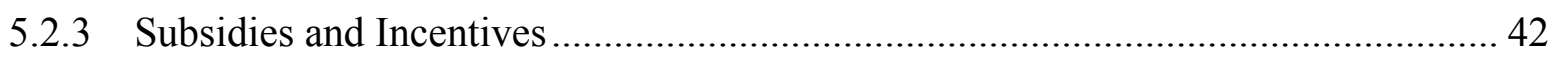




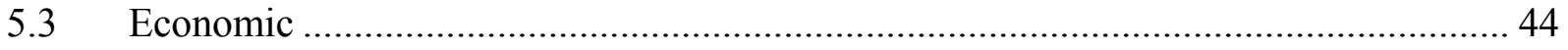

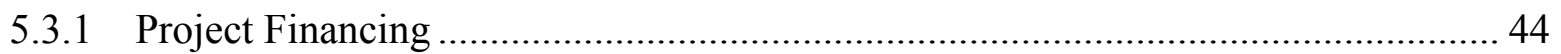

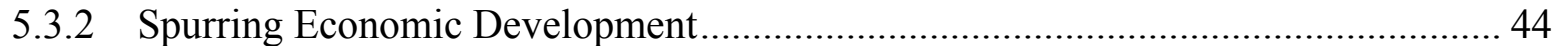

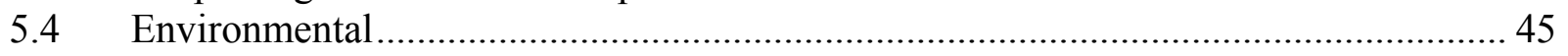

5.4.1 Quality of Solar Resource Data ........................................................................ 45

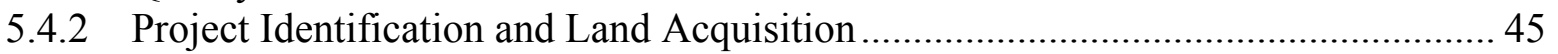

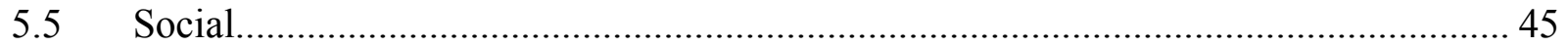

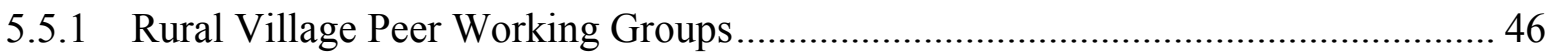

5.5.2 Social Acceptance of Renewable Energy Technologies......................................... 47

5.5.3 Training and Workforce Development ...................................................................... 47

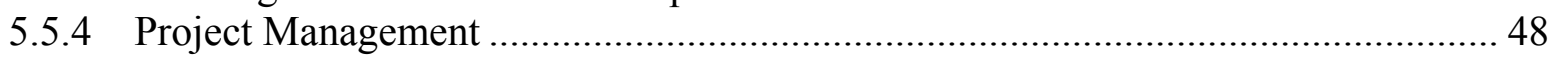

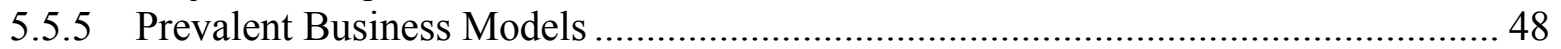

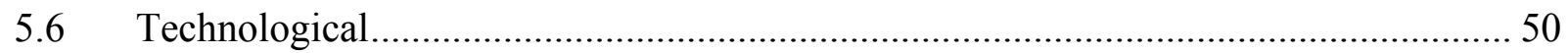

6 Recommendations and Path Forward..........................................................................52

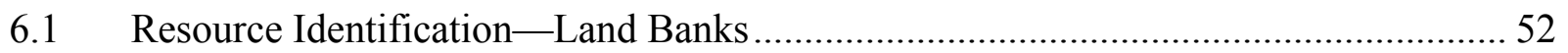

6.2 Streamlining and Standardizing the Project Development Process .............................. 52

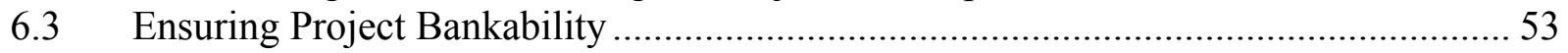

6.4 Developing a Turnkey Systems Approach ………....................................................... 54

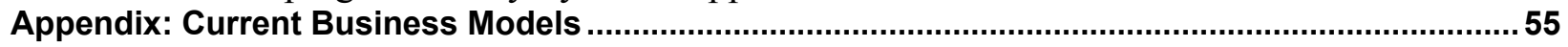




\section{List of Figures}

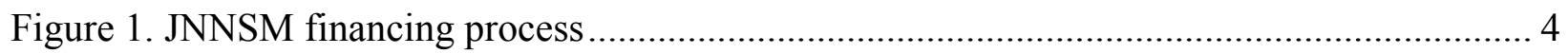

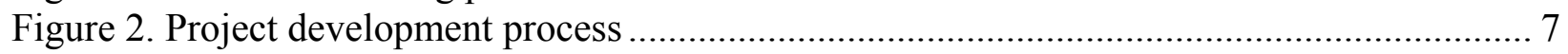

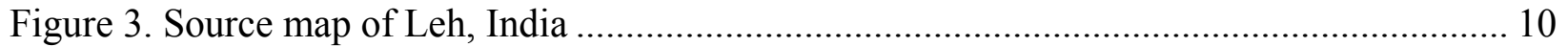

Figure 4. Leh District projected growth in energy demand ..................................................... 11

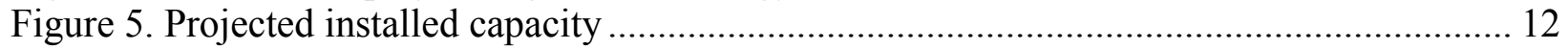

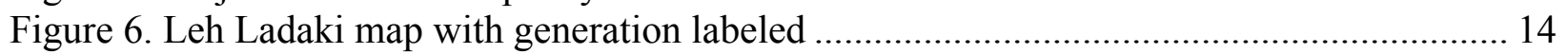

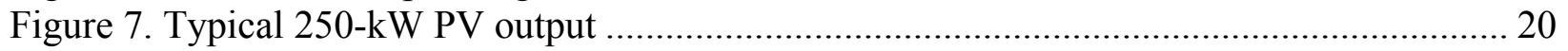

Figure 8. Possible Leh Ladakh technical configuration.............................................................. 21

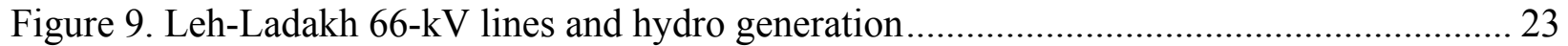

Figure 10. Typical battery operation for constant $60-\mathrm{kW}$ output ................................................ 25

Figure 11. Typical battery operation for constant $75-\mathrm{kW}$ output ............................................... 25

Figure 12. Typical battery operation for constant 250-kW output ............................................. 26

Figure 13. Winter installed capacity (in MW) deficit............................................................. 27

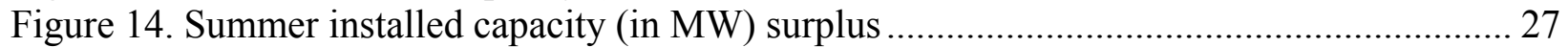

Figure 15. Option 1: scheduling summer/winter (in MW) generation .......................................... 28

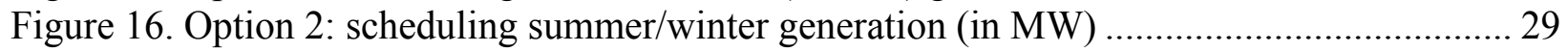

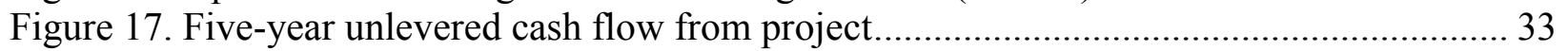

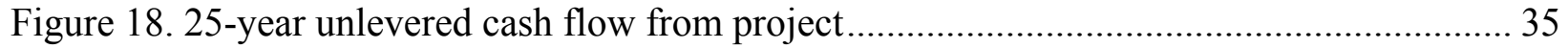

Figure 19. 25-year unlevered cash flow from project............................................................... 37

\section{List of Tables}

Table 1. Annual Targets for Solar Minigrid for the Period 2011-2017 …................................... 2

Table 2. MNRE PV Systems and Components Certifications $>1 \mathrm{kWp}$ [Off Grid] Capacity......... 8

Table 3. 2012 Leh Solar Projects ........................................................................................ 15

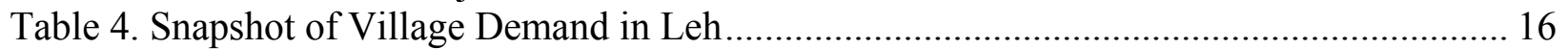

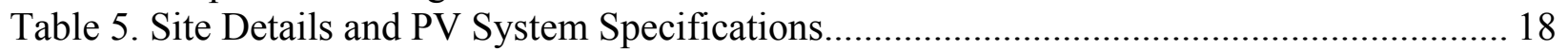

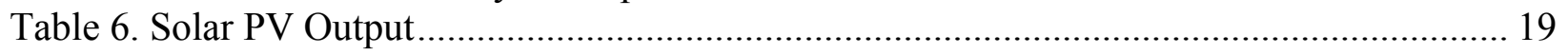

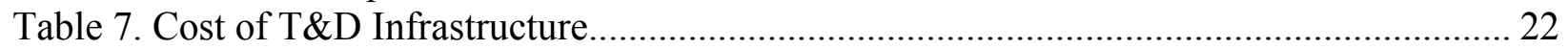

Table 8. Scenarios 1 and 2: State Nodal Agency Develops PV Project ...................................... 32

Table 9. Scenario 3: Private Developer Develops PV Project in Special-Category States ........... 34

Table 10. Scenario 4: Private Developer Develops PV Project in Normal Rural Area................. 36

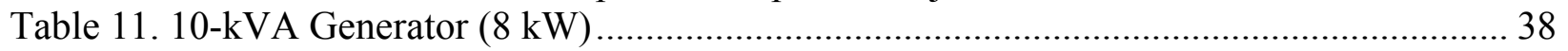

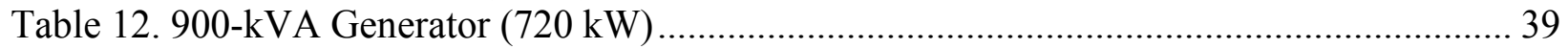

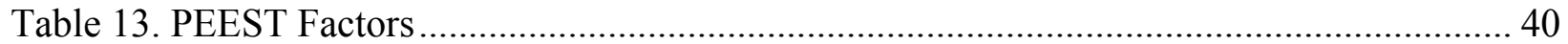

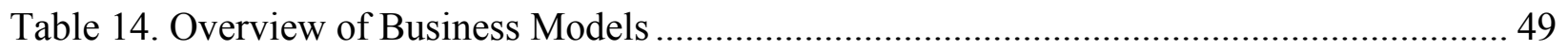

Table 15. Community-Owned Hybrid Model............................................................................... 55

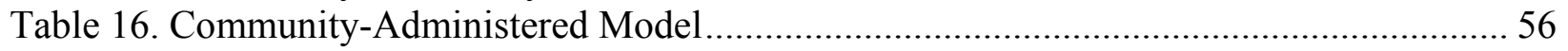

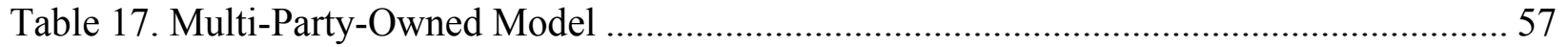

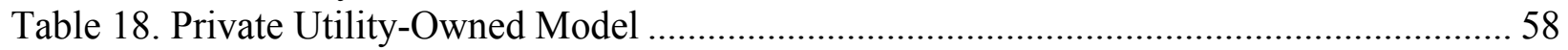

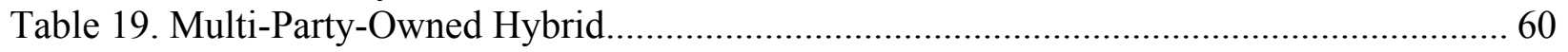




\section{Introduction}

\subsection{Overview of Indian Energy Context}

Due to acute energy shortages, global climate issues, and scarce resources, India cannot pursue a traditional model of energy generation and distribution. Under the U.S.-India Energy Dialogue, the U.S. Department of Energy's (DOE's) National Renewable Energy Laboratory (NREL) is supporting the Indian Ministry of New and Renewable Energy's (MNRE's) Jawaharlal Nehru National Solar Mission (JNNSM) by conducting a review of the opportunities and challenges for solar minigrid development in rural villages.

In January 2010, the government under JNNSM announced the goal of deploying 20 gigawatts (GW) of grid-connected solar power and $2 \mathrm{GW}$ of off-grid solar by 2022 . Their objective is to invest in India's vast solar resources by deploying solar energy on a broad scale and extending modern power services to millions. Specifically, the JNNSM in Phase I of the mission has set the goal of implementing $1 \mathrm{GW}$ of grid-connected solar and 200 megawatts (MW) of off-grid (rural village electrification) by March 2013.

Development of solar technology is considered an attractive alternative that can provide a networked infrastructure of local-grid clusters with distributed electricity generation. That could alleviate the need for expensive, long-distance centralized power delivery systems and at the same time bring electricity to the masses.

\subsection{Market Potential for Solar Minigrids}

In this report, a minigrid is defined as a solar PV plant with a localized distribution network to a single village, or a cluster of villages, providing alternating current (AC). A microgrid is smaller than a minigrid and provides direct current (DC). This is consistent with how the Indian government and industry distinguish between the two. India's projected economic expansion of ( $7 \%-8 \%$ per year) ${ }^{6}$ and growing population are placing a growing strain on the country's energy infrastructure, where up to $40 \%$ of the power generated is lost due to inefficiencies and theft. ${ }^{7}$ Electricity demand per person is expected to grow from 630 kilowatt-hours $(\mathrm{kWh})$ to $1,000 \mathrm{kWh}^{8}$ over the next five years. In addition, there currently exists a demand-supply gap of $12 \%$ on average, and progressive states see a gap in excess of $15 \%{ }^{9}$

As of 2004, there were about 80,000 unelectrified villages in the country. A target for electrifying 5,000 such villages was fixed for the Tenth National Five Year Plan (2002-2007). As of 2004, more than 2,700 villages and hamlets had been electrified mainly using solar photovoltaic (SPV) systems. ${ }^{10}$ However, this still leaves approximately 75,000 villages without access to power.

\footnotetext{
${ }^{6} \mathrm{http}: / / \mathrm{www}$. indianmirror.com/indian-industries/solar.html

${ }^{7}$ Ibid.

${ }^{8}$ Ibid.

${ }^{9}$ Overview of Sustainable Renewable Energy Potential in India, Global Energy Network Institute, 2010.

${ }^{10} \mathrm{http}$ ://indianpowersector.com/renewable-energy/solar-power/
} 
There is also a great need for energy services and solar minigrids in the island regions of India, such as Andaman and Nicobar and the Lakshadweep Islands, which are located on the Bay of Bengal. These islands do not have central grid connectivity and are mostly dependent on diesel generators. Renewable energy project developers have the opportunity to address this need through solar minigrids. At present, the total installed capacity is approximately $70 \mathrm{MW}$, with a peak demand of $40 \mathrm{MW}$ in each island region. The government is also planning a 5-MW SPV power project at South Andaman to supplement diesel generation at an estimated cost of US\$18.04 million (INR 81.23 crores). ${ }^{11}$

\subsection{The Solar Minigrid Solution}

Solar minigrids are an ideal alternative to grid electricity in remote villages that do not have grid connectivity. And because minigrids are independent entities, they can also be controlled and managed without presenting threats to the conventional grid. Such distributed energy systems also provide more reliable electricity, as any outages or interruptions to electricity supply can be quickly identified and corrected. Additionally, having the site of power generation closer to the load also reduces $\mathrm{T} \& \mathrm{D}$ losses.

India's goal is to install a total of $1,100 \mathrm{MW}$ of solar minigrids in the next five years. ${ }^{12} \mathrm{JNNSM}$ is planning for an average system size of $250 \mathrm{~kW}$ covering approximately two to three acres of land in rural areas that currently have little or no connectivity to existing electrical grids.

Estimated project costs for fulfilling this target total approximately US $\$ 4.4$ billion. ${ }^{13}$ MNRE targets for annual solar minigrid development in megawatts are shown in Table 1 below.

Table 1. Annual Targets for Solar Minigrid for the Period 2011-2017

\begin{tabular}{|l|l|l|l|l|l|l|l|l|l|}
\hline $\begin{array}{l}\text { Renewable } \\
\text { Energy } \\
\text { Applica- } \\
\text { tions/years }\end{array}$ & $\begin{array}{l}\text { Cumulative } \\
\text { (likely by } \\
31.3 .11)\end{array}$ & $\begin{array}{l}2011- \\
2012\end{array}$ & $\begin{array}{l}2012- \\
2013\end{array}$ & $\begin{array}{l}2013- \\
2014\end{array}$ & $\begin{array}{l}2014- \\
2015\end{array}$ & $\begin{array}{l}2015- \\
2016\end{array}$ & $\begin{array}{l}\text { 2016- } \\
2017\end{array}$ & $\begin{array}{l}\text { Total } \\
\text { Target } \\
\text { for Six- } \\
\text { Year } \\
\text { Period }\end{array}$ & $\begin{array}{l}\text { Cumulative } \\
\text { Total } \\
\text { Target }\end{array}$ \\
\hline $\begin{array}{l}\text { Decentralized } \\
\text { Solar PV } \\
\text { Systems - } \\
\text { MWp }\end{array}$ & 132 & 68 & 100 & 150 & 200 & 200 & 250 & 968 & 1,100 \\
\hline
\end{tabular}

Source: Ministry of New and Renewable Energy, New Delhi

\footnotetext{
${ }^{11} \mathrm{http}: / /$ www.mfa.go.th/internet/document/6674.pdf

$12 \mathrm{http} / / / \mathrm{mnre}$. gov.in/file-manager/UserFiles/strategic plan mnre 2011_17.pdf

${ }_{13}$ Estimated potential of US $\$ 4.4$ billion in market potential is based on calculations considering 1,100 MW government target by 2017 and with a cost of INR 200 million/MW (US\$4 million/MW). Baseline cost was taken from a project where a 1-kW minigrid was implemented at INR 3 million (US\$60,000/MW).
} 


\section{Government Goals, Policy, and Process}

\subsection{Government Solar Energy Goals}

The government of India expects to invest INR 900 billion (US $\$ 18$ billion) over the next 30 years for increasing access to power in remote and rural areas. MNRE is specifically focusing on India's off-grid rural population, who are in urgent need for power. It is facilitating investment through various microfinance schemes by partnering with rural banks, subsidizing PV systems, and implementing rural electrification schemes such as Rajiv Gandhi Grameen Vikas Yojana (RGGVY) through the Ministry of Power's (MoP) Rural Electrification Corporation (REC).

The objective of JNNSM is to implement 20,000 MW of grid-connected and 2,000 MW of offgrid solar power by 2022 in a three-phased approach. The current mission targets are:

- To create an enabling policy framework for the deployment of 20,000 MW of solar power by 2022 .

- To ramp up capacity of grid-connected solar power generation to 1,000 MW by 2013 , adding 3,000 MW by 2017 through the mandatory use of the renewable purchase obligation by utilities backed with a preferential tariff. This capacity can be more than doubled - reaching 10,000 MW installed power by 2017 or more, based on enhanced international finance and technology transfer. The ambitious 2022 target of 20,000 MW or more will be dependent on the "learning" of the first two phases, which, if successful, could lead to conditions of grid-competitive solar power. The transition could be appropriately scaled up, based on availability of international finance and technology.

- To create favorable conditions for solar manufacturing capability, particularly solar thermal for indigenous production and market leadership.

- To promote programs for off-grid applications, reaching 1,000 MW by 2017 and 2000 MW by 2022 .

- To achieve 15 million square meters of solar thermal collector area by 2017 and 20 million by 2022 .

- To deploy 20 million solar lighting systems for rural areas by $2022 .{ }^{14}$

\subsection{Process for Financing Solar Minigrids}

MNRE has released two documents - the "Guidelines for Off-Grid and Decentralized Solar Application" and the "Solar Off-Grid Refinance Scheme"- that provide the eligibility and implementation process and the funding schemes that institutions can take advantage of in financing solar projects.

The basics of the scheme are outlined in Figure 1 below.

\footnotetext{
${ }^{14}$ Toward Building a Solar India, MNRE, Section 3
} 


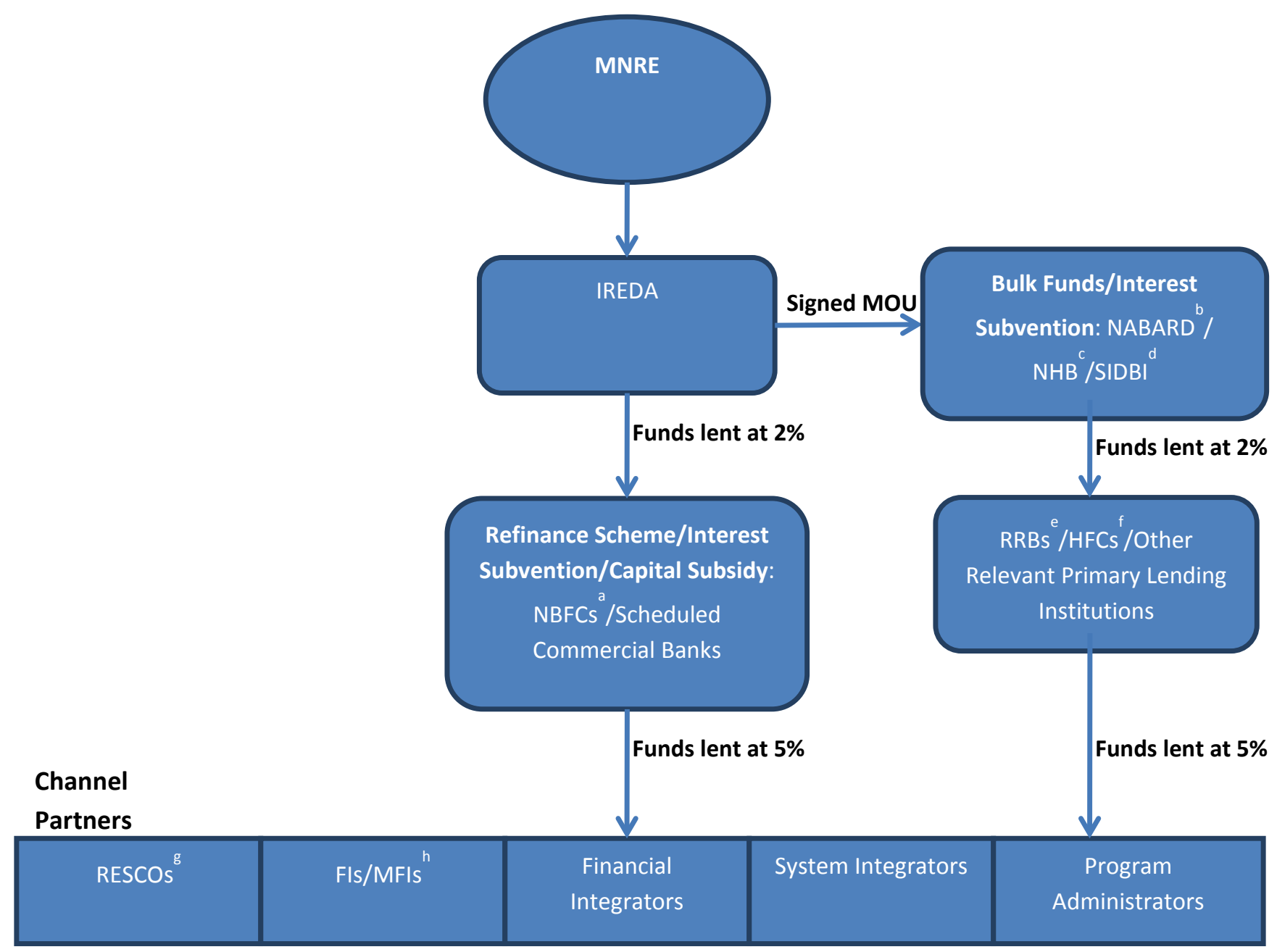

a. nonbanking financial companies; b. National Bank for Agriculture and Rural Development; c. National Housing Bank; d. Small Industries Development Bank of India; e. regional rural banks; f. housing financing companies; g. renewable energy service companies; h. financial institutions/microfinance institutions

Figure 1. JNNSM financing process

As shown in the figure above, all available funding for the National Solar Mission is directed and administered through the Indian Renewable Energy Development Agency (IREDA) per MNRE guidelines to other Indian national banks and primary lending institutions. MNRE will release $50 \%$ of the estimated annual funding required to IREDA at the beginning of the year, while the remaining will be released once $50 \%$ of the first installment has been spent. The recipients are ultimately the channel partners, who, prior to release of any funding, must provide MNRE's Project Approval Committee (PAC) with a project design document that outlines the details of 
the project, including specifics on the "client, technical, and financial details, O\&M and monitoring arrangements." $" 15$ There are five types of channel partners eligible to receive funding:

- Renewable Energy Service Providing Companies (RESCOs): These are companies that would install, own, and operate renewable energy systems and provide energy services to consumers. These entities may link up with financial institutions (FIs) for accessing the financial support under the scheme.

- FIs, including microfinance institutions (MFIs) acting as aggregators: These would be institutions that are involved in consumer finance and have an established base of customers in rural/urban areas and outreach through self-help groups, etc. These would typically access interest subsidy through a refinance facility and also credit-linked capital subsidy on behalf of their borrowers from IREDA.

- Financial integrators: These are entities that would integrate different sources of finance, including carbon finance, government assistance, and other sources of funds, to design financial products/instruments and make these available to their clients at an affordable cost. These entities would link up with manufacturers and service providers.

- System integrators: These are companies/entities that would provide renewable energy systems and services to clients, including design; supply; integration and installation; O\&M; and other services. These entities may link up with FIs for accessing the financial support under the scheme.

- Program administrators: These would include inter alia, central and state government ministries and departments and their organizations, state nodal agencies, utilities, local bodies, public sector undertakings ${ }^{16}$, and reputed nongovernmental organizations (NGOs). These entities would directly implement the scheme and access capital subsidy (noncredit linked) from MNRE. ${ }^{17}$

Upon approval of the project, channel partners are free to apply for the capital subsidy or soft loan through their lending institution. This in turn will set the process in motion to release funding to the channel partner.

Once the project approval document is received by IREDA, there are multiple ways in which channel partners can avail themselves of funding as detailed in Section 4 of MNRE's Solar OffGrid Refinance Scheme-

- Capital subsidy: will be available at a level of $30 \%$ of the expected cost of the project for all regions in India, except special-category states ${ }^{18}$, which will receive the subsidy at a rate of $90 \%$. The primary lending institution is ultimately accountable to ensure that projects are successfully implemented before the subsidies can be released to borrowers. For program administrators (channel partners) the funding could be released up front with $70 \%$ on approval by the MNRE PAC and $30 \%$ on completion. However to meet "unmet community demand for electricity or in unelectrified rural areas, standalone rural SPV power plants with battery storage in a MICRO grid model/local distribution network, would be provided Rs. 150/Wp (US\$3/Wp) of capital subsidy and soft loan at 5\%."

\footnotetext{
${ }^{15}$ Guidelines for Off-Grid and Decentralized Solar Application, Section 5.1.

${ }^{16}$ Companies owned by the Indian central or state government.

${ }^{17}$ Guidelines for Off-Grid and Decentralized Solar Application, MNRE, Section 4.2.

${ }^{18}$ Special-category states include North East, Sikkim, Jammu and Kashmir, Himachal Pradesh, and Uttarkhand. In addition, other remote areas like Lakshadweep, Andaman and Nicobar Islands, and districts on India's international borders will also be eligible.

${ }^{19}$ Appendix 1A, Boundary Conditions for Support to Off-Grid Solar PV Applications
} 
- The scale of the capital subsidy is based on annual benchmarking.

- As of 2011, the benchmark price for PV systems with battery back-up is Rs. 270/Wp (US\$5.40/Wp).

- Refinance scheme: would allow for a low-interest loan on the balance of the funding needed for a project - after the developer contributes $20 \%$ equity to the project and after the capital subsidy. So up to $50 \%$ (based on the credit of the financial institution) of the project funding can be financed via the refinance mechanism. IREDA will lend funds to the primary lending institution at an interest rate of $2 \%$, provided the channel partner is charged an interest rate of no more than $5 \%$.

- Bulk funds: will be made available to NABARD, NHB, and SIDBI under a memorandum of understanding (MOU) that is signed between IREDA and the corresponding institution; $50 \%$ of the projected amount of funds needed for the year (as established by the institution) will be disbursed in the beginning of the year, and once those funds have been lent, the rest of the money will be disbursed. The MOU will set the terms of the bulk funds to five years, and these funds will have to be repaid to IREDA within five years, irrespective of whether the borrower has repaid the money to the institution. The refinancing institutions can then lend the money to regional rural bands, housing finance companies, and other primary lending institutions at a rate of $2 \%$, provided that the rate provided to borrowers is no more than $5 \%$.

- Interest subvention: can be used in place of bulk funds by an Indian government institution or in place of refinance by a private lending institution. The interest subvention rate applied toward Indian national banks, such as NABARD, will be based on the government security rates set by the Fixed Income Money Market and Derivatives Association (FIMMDA) of India, and the rates of primary lending institutions will be the FIMMDA rates plus 2 percentage points. IREDA will lend funds to the primary lending institution at an interest rate of $2 \%$, provided the channel partner is charged an interest rate of no more than $5 \%$.

\subsection{Current Project Development Process}

Based on conversations with the Ladakh Renewable Energy Development Agency (LREDA), an MNRE nodal agency, there are currently multiple ways a solar minigrid project can be developed; this process is likely similar to how it works in other states as well. As shown in Figure 2 below, a village or town can work with different categories of MNRE preapproved channel partners for developing solar PV projects. These projects fit into two broad categories:

1. If a local village submits a request for electrification to a program administrator, such as MNRE's state nodal agency (SNA) in their region, the SNA then conducts a feasibility study and sends it to MNRE's PAC for approval. Once approved, the agency receives $30 \%$ or $90 \%$ of the capital subsidy (depending on the region) and contributes $70 \%$ or $10 \%$. The SNA then issues a request for proposal (RFP). The bidder must respond by proposing a rate that will enable the bidder to recover the investment and receive a return in the first five years, after which the project is turned over to the village and SNA. Each SNA might follow a slightly different approach, but in general, once a developer is selected from the tendering process, 
the developer receives $50 \%$ of the funds prior to construction to cover a portion of the capital costs. Once the plant has been built, the developer receives an additional $45 \%$ of the capital subsidy and then $1 \%$ each year, for five years, for operations and maintenance (O\&M) costs. The developer is expected to train two people from the local village to perform the O\&M for the next 20 years, assuming a 25-year project life. A Village Electrification Committee (VEC) is formed at the beginning of the project to collect revenue from the village customers. As observed, Rs. 100 is collected from households that are below the poverty line, and Rs. 200 is collected from those above the poverty line. Thereafter, a monthly fee of Rs. 20 to Rs. 45 is collected for the creation of a fund used to pay for future maintenance costs, such as battery and inverter replacement. The VEC appoints a graduate of the Government Industrial Training Institute to perform regular and unscheduled O\&M.

2. A solar project developer, including renewable energy service companies (RESCOs), FIs/MFIs, financial integrators, and system integrators, can work directly with a village to develop a solar project. These entities install the system and are expected to operate and maintain the plant for 25 years. In return, they receive all revenues from plant operation and capital subsidy from the government. The first $70 \%$ of the subsidy $(30 \%$ or $90 \%$, depending on the region) is paid out in advance of construction. The remaining $30 \%$ is paid out postconstruction. Depending on the region, the developer contributes $10 \%$ or $70 \%$ of the capital cost.

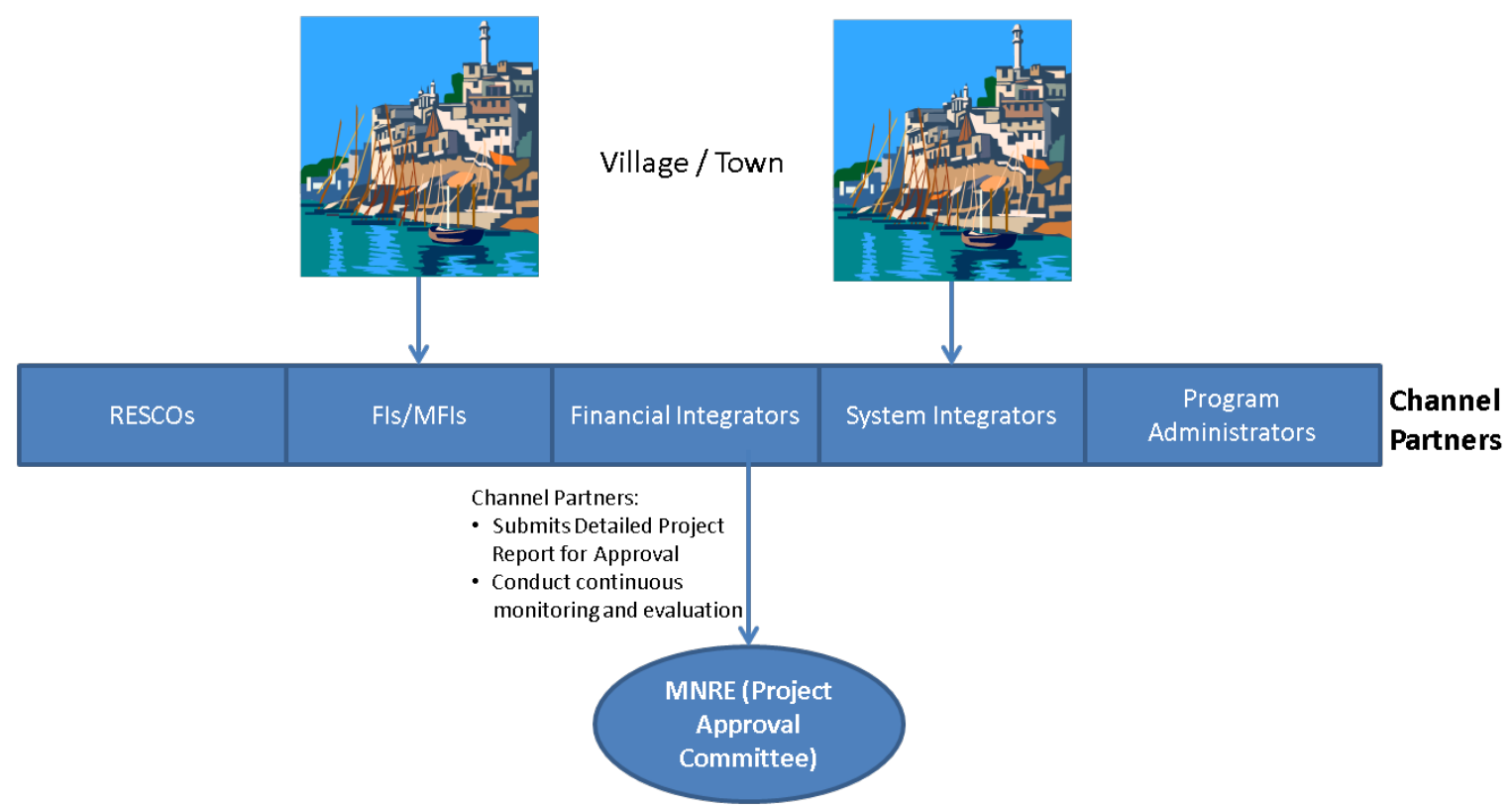

Figure 2. Project development process

As per MNRE norms, it is mandatory that Indian-made solar modules be used to claim the subsidy and other benefits. The peripheral parts of the system can be imported, but the government proposes that developers use as much domestic content as possible. However, thinfilm PV modules, which are not manufactured in India, can be imported. MNRE certifications for PV systems and components greater than 1 kilowatt-peak $(\mathrm{kWp})$ capacity are shown in Table 2 below. 
Table 2. MNRE PV Systems and Components Certifications $>1$ kWp [Off Grid] Capacity

\begin{tabular}{|c|c|c|c|}
\hline & Components & Certifications & Description \\
\hline 1. & Solar PV module & $\begin{array}{l}\text { IEC 61215, IEC 61646, } \\
\text { IEC } 62108 \text { or IS } 14286\end{array}$ & $\begin{array}{l}\text { Use of RFID is mandatory in all types of PV } \\
\text { modules, regardless of their capacity, when } \\
\text { used in such systems. }\end{array}$ \\
\hline 2. & Solar inverter & IEC 61683, IEC 60068 & $\begin{array}{l}\text { Inverter should also qualify damp heat } \\
\text { cycling/study state and thermal cycling (as per } \\
\text { the relevant standard). It should also qualify } \\
\text { the hammer test and robustness of } \\
\text { terminations and drop test. }\end{array}$ \\
\hline 3. & Batteries & $\begin{array}{c}\text { IEC } 61427, \text { IS } 1651, \text { IS } \\
13369 \text { or IS } 15549\end{array}$ & $\begin{array}{l}\text { If any of the given certificates is not available, } \\
\text { the battery should qualify the tests } \\
\text { corresponding to capacity (as per } \mathrm{C} / 10 \text { or } \mathrm{C} / 20 \\
\text { rate), efficiency of watt-hour and amp-hour, } \\
\text { and charge retention shelf life irrespective of } \\
\text { type/capacity of battery. }\end{array}$ \\
\hline 4. & Housing & $\begin{array}{l}\text { IP65 standard, IP21 } \\
\text { standard }\end{array}$ & $\begin{array}{l}\text { The field and array junction boxes have to } \\
\text { comply with IP65 standard. The electronics, } \\
\text { including inverters, CPU, charge controllers, } \\
\text { MPPTs, and AC \& DC distribution boxes, } \\
\text { should have IP } 21 \text { standards. }\end{array}$ \\
\hline 5. & $\begin{array}{l}\text { Cables, } \\
\text { connectors, } \\
\text { switches \& circuit } \\
\text { breakers }\end{array}$ & - & $\begin{array}{l}\text { Standards for cables, switches, circuit } \\
\text { breakers, connectors, junction boxes, and } \\
\text { enclosures will remain the same as in the } \\
\text { administrative approval. All components of } \\
\text { the system should conform to standard, and } \\
\text { the composite system should also be certified } \\
\text { with testing laboratories. }\end{array}$ \\
\hline 6. & $\begin{array}{l}\text { SPV system } \\
\text { design \& } \\
\text { installation } \\
\text { practices }\end{array}$ & $\begin{array}{c}\text { IEC } 62124 \text { and IEC } \\
60364-7-712\end{array}$ & $\begin{array}{l}\text { A committee of PV experts/consultants will } \\
\text { study the standards and identify the minimum } \\
\text { requirements, and the same will be intimated. }\end{array}$ \\
\hline 7. & Energy meters & 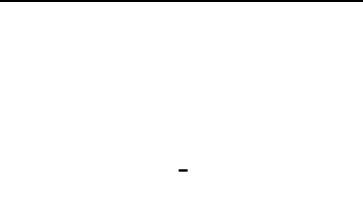 & $\begin{array}{l}\text { All PV power plants above } 1 \mathrm{kWp} \text { have to } \\
\text { install energy meters for accounting and also } \\
\text { have to provide energy delivery guarantee for } \\
\text { the customers. }\end{array}$ \\
\hline
\end{tabular}




\subsection{Current Activities of Private Companies}

During the course of completing this project, NREL conducted interviews with a number of leading Indian solar technology companies to understand their current and future strategies for involvement in the solar minigrid space. We also hoped to uncover some of the challenges currently preventing large-scale deployment of solar projects, through the lens of a private solar developer. Specifically, we spoke with the following companies: Tata BP Solar, Orb Energy, Wipro Eco Energy, Eversun, and Kotak Urja. We also spoke with Husk Power, which has had a success in employing a rural business model generating electricity from biomass, and with its financing partner Acumen.

Although several of the companies were providing solar solutions to rural India, none of the companies we spoke to were currently using smart grid technology/smart metering to provide electricity. Also, none of the companies have built a minigrid system greater than $50 \mathrm{~kW}$. The companies believe that a modular approach to building solar resources, as in the case of a minigrid, offers a better solution than centralized generation and transmission. The costs and energy losses associated with transmission and distribution of power was also noted as a problem.

Many felt that until solar plant costs come down further, solar-lighting of villages may have to be funded through subsidies. With a solar minigrid solution, the village user would have to bear the full cost of electricity. Even a 30\% subsidy combined with a low-interest loan could offer a viable alternative to the user. This loan could come from a local bank that is subsidized by the government, which enables the bank to lend to the end user at a lower interest rate. In order to foster economic development and growth, individuals must have the ability to have access to energy to run home-based businesses, such as weaving textiles using power looms or running flour grinders.

In addition to the above, other companies currently working in the rural energy sector include Mera Gao Power, Azure Power, SunEdison, Solar Semiconductor and Solar Infra, and Minda Group. 


\section{Technical Analysis}

To better understand the economics of minigrids, NREL worked with electricity capacity and demand data supplied by LREDA from the Leh District in Ladakh, India. This data was used to develop a high-level minigrid configuration to determine overall project economics for LehLadakh. The results of this analysis provide us with a reference point for how solar minigrid project economics might look in other regions of the country as well. The state of Jammu and Kashmir qualifies for a much higher subsidy under the JNNSM, since it is considered a specialcategory state due to its remote location.

\subsection{Overview of Leh/Ladakh}

Leh District in the Ladakh region in the state of Jammu and Kashmir in northern India covers an area of approximately 45,000 square kilometers. A map of the region is shown in Figure 3 below. The population of Leh is roughly 117,000 , with 27,500 people living in the city of Leh, the largest in the region. Leh District is further broken down into blocks, each made up of several villages, which contain several hundred households and a few businesses.

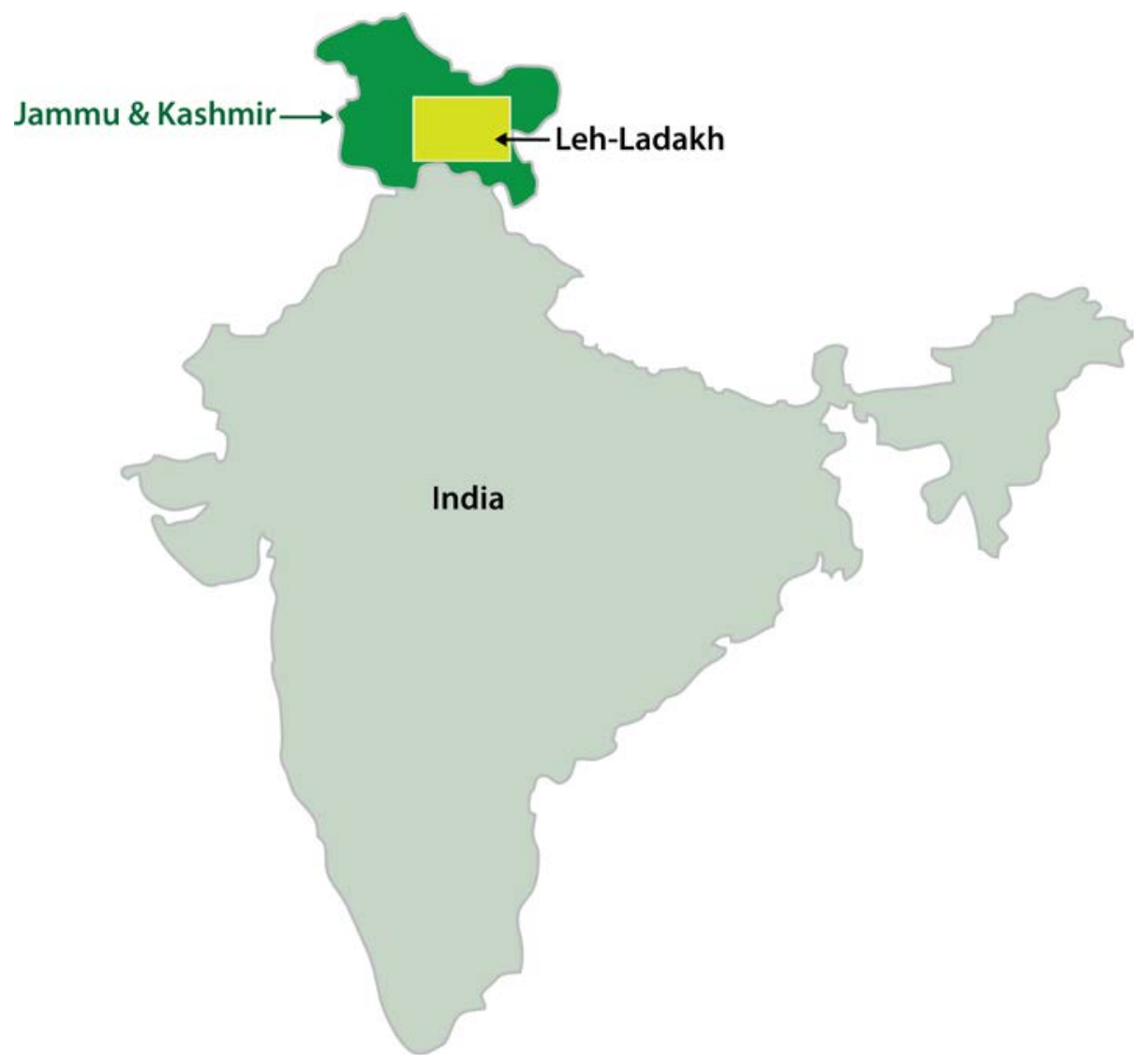

Figure 3. Source map of Leh, India

Illustration by NREL 
The Leh District government, the Ladakh Autonomous Hill Development Council (LAHDC), has identified the power and energy sector as one that requires development. There are two programs within the government of India charged with the responsibility of rural electrification - the RGGVY of the MoP and the JNNSM under MNRE's nodal agency LREDA. The former is responsible for developing rural electricity infrastructure and household electrification, while the latter has the responsibility of all rural renewable energy projects in Ladakh. LREDA is therefore responsible for many of the hydro, solar PV, and solar thermal projects in the Ladakh Renewable Energy Initiative.

\subsection{Current Installed Capacity}

The current installed capacity in Leh District is $23.14 \mathrm{MW}$, of which diesel makes up 15.2 MW and hydro and solar comprise $7.8 \mathrm{MW}$ and $140 \mathrm{~kW}$, respectively. According to LREDA, the power demand of Leh District was $58.53 \mathrm{MW}$ in 2005 and grew at an average rate of $7 \%$ a year to $87 \mathrm{MW}$ in 2011. Assuming the same growth rate for subsequent years, the current demand for energy is in the range of $93.6 \mathrm{MW}$ and is expected to grow to $107 \mathrm{MW}$ by 2014, as shown in Figure 4 below.

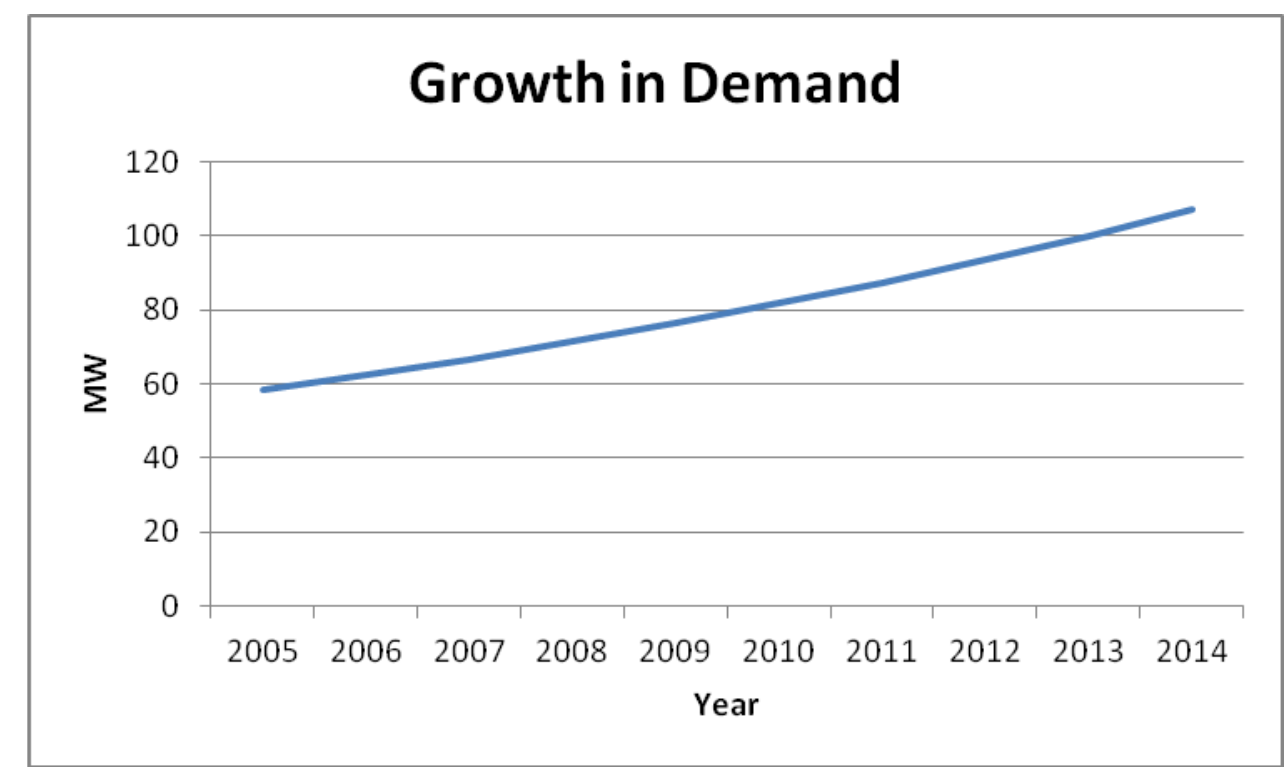

Figure 4. Leh District projected growth in energy demand

Figure 5 shows the projected installed capacity by 2014. In order to help meet the growing energy demand, Leh District is implementing several large and small hydro and PV projects that will bring the installed capacity to nearly $80 \mathrm{MW}$ by the end of 2014 . 


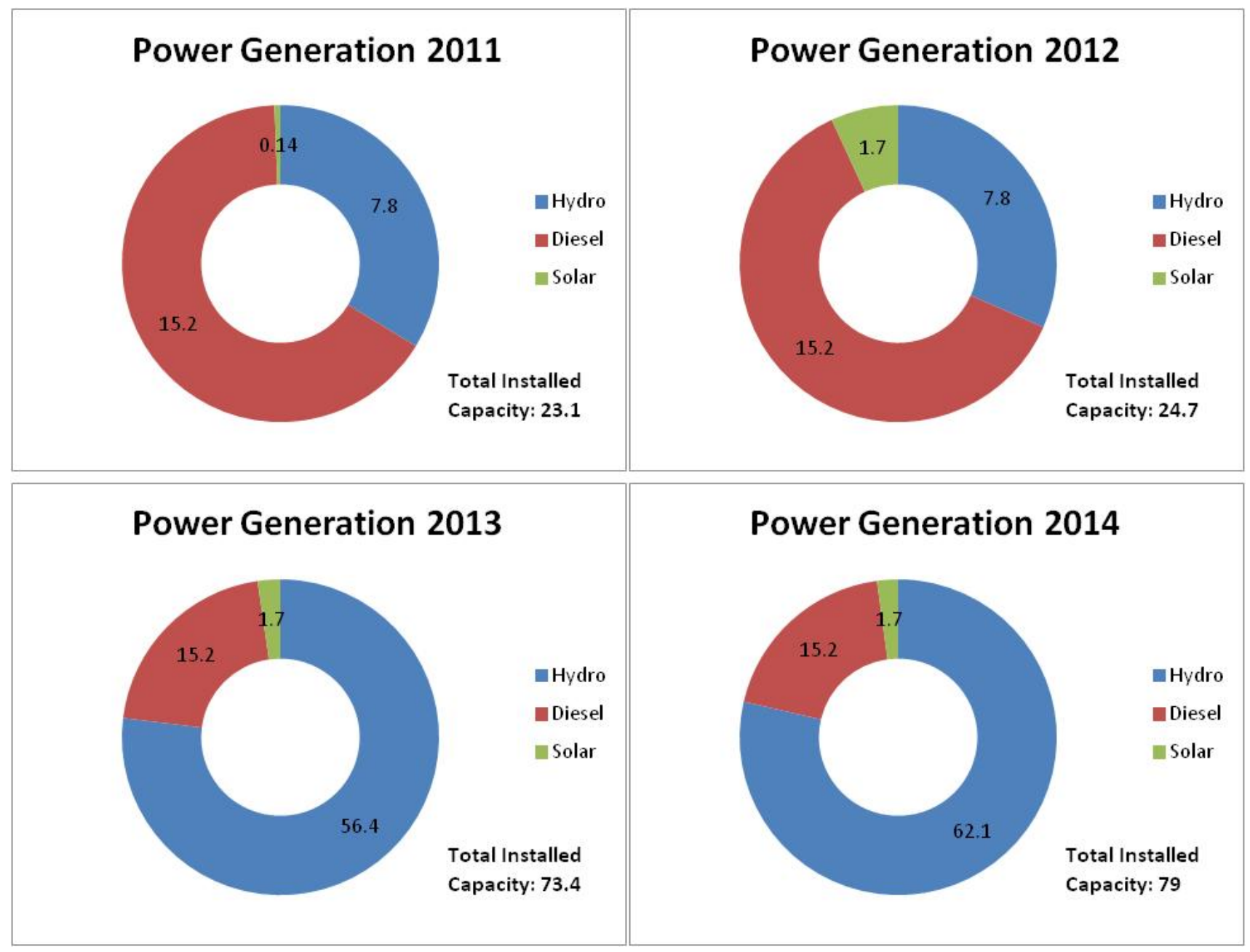

Figure 5. Projected installed capacity

Source: LREDA

\subsubsection{Current Use of Diesel and Hydro}

More than $65 \%$ of the current installed capacity is diesel generation, which is heavily subsidized at the state and local levels. Many of the villages in Leh District get a majority of their power from small local diesel engine generators rated less than 250 kilovolt-amps (kVA) each. The city of Leh, which has the largest load, also has the largest diesel generators with a combined capacity of more than $10 \mathrm{MW}$. The diesel fuel is procured by the Jammu and Kashmir Power Development Department (JKPDD), and the generators are jointly owned by JKPDD, Jammu and Kashmir Power Development Corporation (JKPDC), and LREDA.

As discussed earlier, much of the growth in demand is being addressed through the commissioning of several large hydropower plants in Leh District. Hydro generation is expected to grow from a current capacity of $7.8 \mathrm{MW}$ to $62.1 \mathrm{MW}$ in just two years, from the construction of the 45-MW Nimoo Basgo Hydro Project in Alchi, a 4-MW project in the village of Stakna, a 3-MW project in the Kharu Block of Leh District (all indicated in Figure 6 below), and 22 small 
micro-hydro projects in the Nubra Valley (situated between Panamik and Kharu). Under the current installed capacity of $23 \mathrm{MW}$, electricity is supplied for just five hours a day during the evening hours. These hydro projects are expected to provide an additional three to seven hours for seven months of the year, with very little in the winter due to freezing of the river. While many of the micro-hydro plants freeze during the winter months, the 45-MW Nimoo Basgo plant is expected to produce a third of the power during that period. Therefore, in the winter months, by the end of 2014 the installed capacity will be effectively just $31.85 \mathrm{MW}$ (17 MW diesel and solar combined and 14.85 MW of hydro from Nimoo Basgo). 


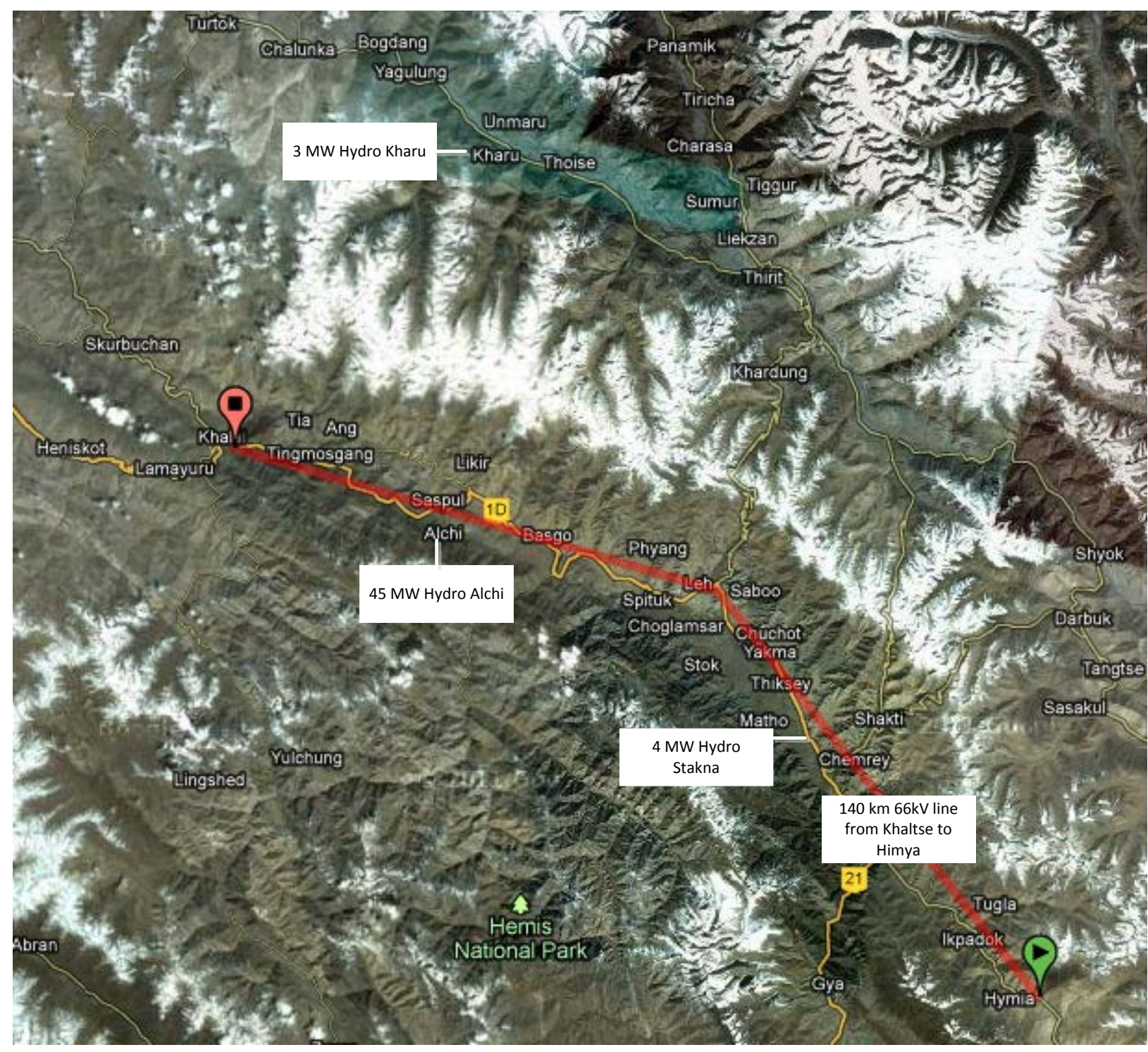

Figure 6. Leh Ladaki map with generation labeled

Source: Google Maps, illustration altered by Daniel Martin, NREL

The map above also shows in red the existing $66-\mathrm{kV}$ subtransmission line from Khaltse to Hymia that will transmit the power from the 45-MW hydro project. At the state level, JKPDD is responsible for developing the electrical T\&D infrastructure within the state. Along this subtransmission line, there are six substations that step down the voltage from $66 \mathrm{kV}$ to $11 \mathrm{kV}$. There are approximately four to seven lines at the $11-\mathrm{kV}$ distribution level outgoing from the substations to serve the local demand at the villages. Additionally, step-down transformers with capacity ratings of $25 \mathrm{kVA}$ and $10 \mathrm{kVA}$ exist at the village level in each block. 


\subsubsection{Solar Generation}

The current solar installed capacity in Leh District is $140 \mathrm{~kW}$, comprising a $100-\mathrm{kW}$ minigrid in Tangste and a 40-kW one in Nyoma. In 2001-2002, LREDA completed electrification of 39 census villages (over 10,000 households) in Leh District through Solar Home Lighting Systems (HLS). However, many of these systems are not in use since the 12-volt (V) lead-acid batteries are no longer operational. Table 3 below shows 43 solar projects that are currently being implemented by LREDA, which will bring the total solar installed capacity to $1.7 \mathrm{MW}$. These projects are expected to be completed by 2012 .

Table 3. 2012 Leh Solar Projects

\begin{tabular}{|l|r|l|r|}
\hline Block & kW & Block & kW \\
\hline Umlung & 5 & Nyiarags & 25 \\
\hline Hangker & 7.5 & Markha & 25 \\
\hline Rumbak & 7.5 & Bokshado & 25 \\
\hline Doltokling & 7.5 & Yarath & 25 \\
\hline Waris/Fastan & 7.5 & Nemgo & 32.5 \\
\hline Khastath & 7.5 & Rokchan & 32.5 \\
\hline Relay & 10 & Satho & 37.5 \\
\hline Lukung & 12.5 & Photoksar & 37.5 \\
\hline Kaya & 12.5 & Merak & 40 \\
\hline Maan & 15 & Largiab & 40 \\
\hline Ankung & 15 & Yourgo & 42.5 \\
\hline Chipra & 15 & Koyul & 85 \\
\hline Parma & 20 & Khaldo & 85 \\
\hline Shayok & 20 & Pungog & 42.5 \\
\hline Dipling & 20 & Hanley TR & 85 \\
\hline Hunder Dok & 20 & Deggar & 50 \\
\hline Demjok & 20 & Chuchul & 115 \\
\hline Lingshed & 80 & Kharnak & 57.5 \\
\hline Niddar & 20 & Nyoma & 115 \\
\hline Kherapulu & 25 & Mudth & 65 \\
\hline Skumpata & 25 & Korzok & 100 \\
\hline Yulchung & 25 & & \\
\hline Total & & & $\mathbf{1 , 5 6 0}$ \\
\hline
\end{tabular}

Source: LREDA 


\subsection{Energy Needs}

The large majority of the villages in Leh District are situated along various rivulets of the Indus, Shayok, and Siachen Rivers. They are separated from one another over an average distance 1012 kilometers $(\mathrm{km})$ between adjacent villages.

As mentioned earlier, the current installed capacity of $23.14 \mathrm{MW}$ of mostly diesel generators, between $100 \mathrm{~kW}$ and $250 \mathrm{~kW}$ per village meets basic power demand such as lighting for a period of five hours a day year round, mostly during the evening hours of 6-11 p.m. Upon completion, the new hydro plants will provide electricity during the summer months but will be minimally to nonoperational during the winter months due to freezing of the rivers. Heating in the winter is achieved by burning wood, kerosene, or liquid propane gas. Solar has the capability of providing much-needed energy year-round, and thus, increasing energy security for the region.

The JKPDD has started metering all households in Leh District and has removed restrictions on types of load. The typical usage of electricity in the village households are for lighting (either incandescent light bulbs or compact fluorescent lamps [CFLs]), operation of televisions and music systems, and charging of cell phones. A few households also use washing machines, refrigerators, and computers, among other electrical appliances.

Table 4 below provides a snapshot of the energy deficiencies experienced in villages in different blocks within Leh District. According to discussions with LREDA, the JKPDD estimates household power demand at 500 watts (W) in several blocks; however, per studies conducted by the Ladakh Ecological Development Group (LEDeG) in 2004, the current average connected load per household is approximately $160 \mathrm{~W}$. The reason behind this discrepancy is that many households choose to have minimal electrical appliances as a result of the intermittency of electricity supply and strict controls imposed by the government on use. In other words, if electricity were more reliable, people would use more of it.

Table 4. Snapshot of Village Demand in Leh

\begin{tabular}{|c|c|c|c|c|c|}
\hline $\begin{array}{l}\text { Table 1: BLOCK- } \\
\text { WISE } \\
\text { DISTRIBUTION } \\
\text { OF ENERGY } \\
\text { REQUIREMENTS } \\
\text { Serial No. }\end{array}$ & Block & $\begin{array}{l}\text { Number of } \\
\text { Households } \\
\text { (source: } 2001 \\
\text { census) }\end{array}$ & \begin{tabular}{|l|} 
Average \\
Connected Load \\
Per Household \\
(W) \\
(source: survey \\
conducted by \\
LEDeG in 2004)
\end{tabular} & $\begin{array}{l}\text { Required } \\
\text { Connected Load } \\
\text { Per Household } \\
\text { (W) }\end{array}$ & $\begin{array}{l}\text { Peak Energy } \\
\text { Requirement for } \\
\text { Domestic Use as } \\
\text { Per Required } \\
\text { Load (kW) }\end{array}$ \\
\hline 1 & Diskit & 2,305 & 115 & 500 & 1,153 \\
\hline 2 & Panamik & 1,067 & 115 & 500 & 534 \\
\hline 3 & Chuchot & 2,671 & 186 & 500 & 1,336 \\
\hline 4 & Durbuk & 951 & 78 & 500 & 476 \\
\hline 5 & Khaltsi & 2,641 & 115 & 500 & 1,321 \\
\hline 6 & Kharu & 1,566 & 98 & 500 & 783 \\
\hline 7 & Leh & 3,350 & 140 & 500 & 1,675 \\
\hline 8 & Nyoma & 2,082 & 137 & 500 & 1,041 \\
\hline 9 & Saspol & 934 & 186 & 500 & 467 \\
\hline 10 & Leh Town & 6,580 & 432 & 1,000 & 6,580 \\
\hline TOTAL & & 24,147 & & \multicolumn{2}{|c|}{ 15,166 (15.16 MW) } \\
\hline
\end{tabular}

Source: LREDA 
In addition to household demand, there is a high demand for commercial loads in several blocks, which is estimated at $2 \mathrm{~kW}$ per commercial customer. The commercial establishments are mostly situated in the town of Leh and the adjoining area of Choglamsar, in Leh Block. There are other commercial developments at Khaltse (Khaltsi Block), Diskit, Kharu (Kharu Block), Tangste (Durbuk Block), and Nyoma (Nyoma Block). They comprise between two and five small shops within each village, which sell consumer products. Loads in the Leh Block, Khaltse Block, Chuchot Block, and Kharu Block are expected to grow more than the 7\% average.

\subsection{Leh District Solar PV Energy Production}

To determine the total kilowatt-hour output of solar PV, a customized weather file was created from data developed by NREL's Renewable Resource Data Center (RReDC).

This data was then processed using NREL's SolOpt ${ }^{20}$ tool to determine total kilowatt-hour output from standard PV crystalline silicon panels. The site details and PV panel assumptions used for the simulation are shown in Table 5 below.

\footnotetext{
${ }^{20}$ For more information, please see www.nrel.gov for more information http://www4.eere.energy.gov/solar/sunshot/resource center/resources/solopt optimization tool
} 
Table 5. Site Details and PV System Specifications

\begin{tabular}{|l|c|}
\hline & Results \\
\hline Site location & Leh, India \\
\hline Latitude & $34^{\circ} \mathrm{N}$ \\
\hline Longitude & $77^{\circ} \mathrm{E}$ \\
\hline System size/capacity & $250 \mathrm{~kW}$ \\
\hline Number of panels & $1,434\left(14 \mathrm{ft}^{2}\right.$ each) \\
\hline Mounting surface & $\mathrm{Ground}$ \\
\hline Rated panel power & 174.24 \\
\hline Panel efficiency & $13.4 \%$ \\
\hline Panel tilt & $34^{\circ}$ \\
\hline Derate factor & $80 \%$ \\
\hline Panel availability & $100 \%$ \\
\hline
\end{tabular}

Before installing a PV system, panel and rack manufacturers should be consulted to confirm the rated wind load for mounting systems, and roof conditions should be examined if applicable. 
Based on the input, SolOpt estimates total electricity production over a 12-month period at $427,737 \mathrm{kWh}$. The breakdown by month is given in Table 6 below.

Table 6. Solar PV Output

\begin{tabular}{|c|c|}
\hline \multicolumn{2}{|c|}{ Power Production (AC) } \\
\hline Jan & 17,687 \\
\hline Feb & 27,603 \\
\hline Mar & 40,633 \\
\hline Apr & 39,972 \\
\hline May & 39,504 \\
\hline Jun & 39,254 \\
\hline Jul & 36,544 \\
\hline Aug & 37,888 \\
\hline Sep & 39,296 \\
\hline Oct & 42,841 \\
\hline Nov & 39,111 \\
\hline Dec & 27,405 \\
\hline Total & 427,737 \\
\hline
\end{tabular}

The maximum electricity production is expected during October, and the minimum production occurs in January. PV production in the summer months occurs from 6 a.m. to 6 p.m. Currently the village is supplied electricity from 6 p.m. to 11 p.m. In the absence of interval data, it is a best guess to assume that peak demand likely occurs during the same time interval. From September to March, during the winter months, PV does not produce after 5 p.m. Energy storage is therefore needed to fill the gap in supply during the summer and winter months.

Figure 7 below shows the average simulated solar output of a $250-\mathrm{kW}$ system in Leh during the first 15 days in June. The peak is usually between $200 \mathrm{~kW}$ and $250 \mathrm{~kW}$ for the region, since the irradiance is above the rated $1,000 \mathrm{~W} / \mathrm{m}^{2}$. 


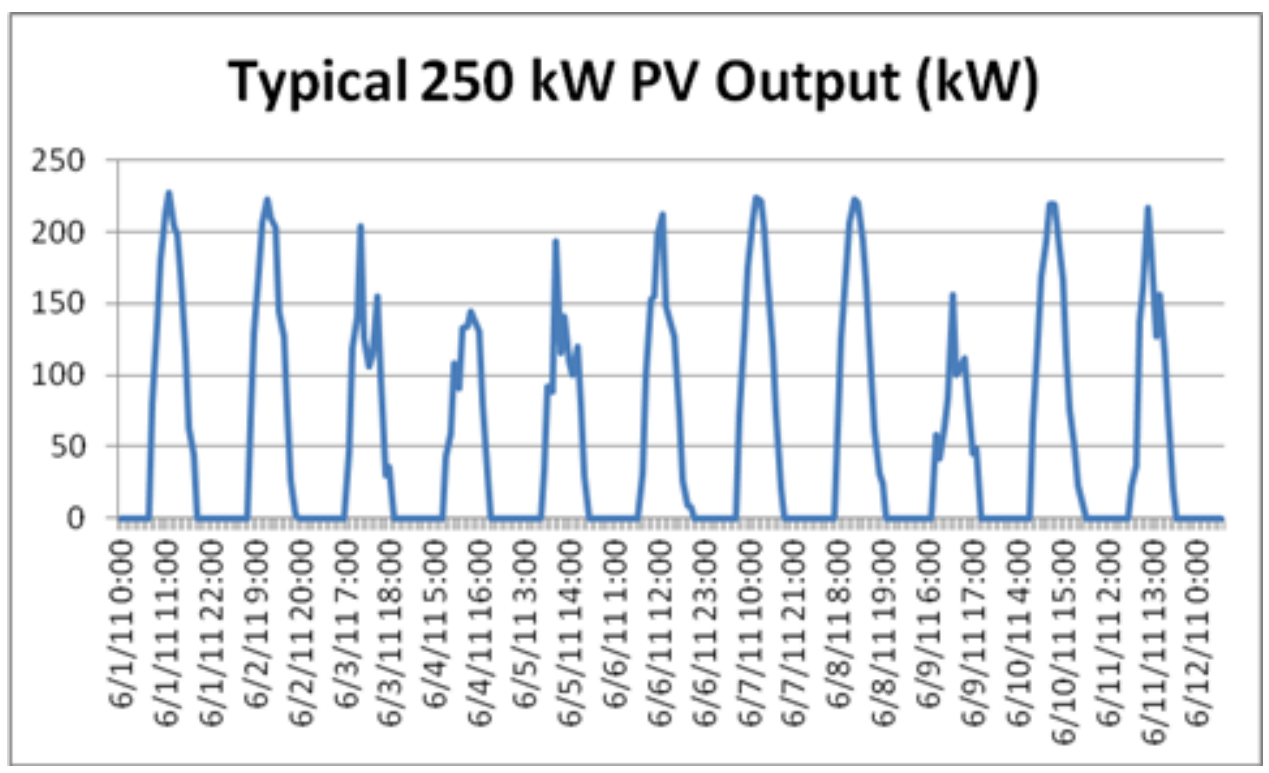

Figure 7. Typical 250-kW PV output

\subsection{Suggested Technical Configuration}

As illustrated in Figure 8 below, a stand-alone 250-kW system can be built to address the electrification needs of different types of villages, from the partially electrified to the completely unelectrified. 


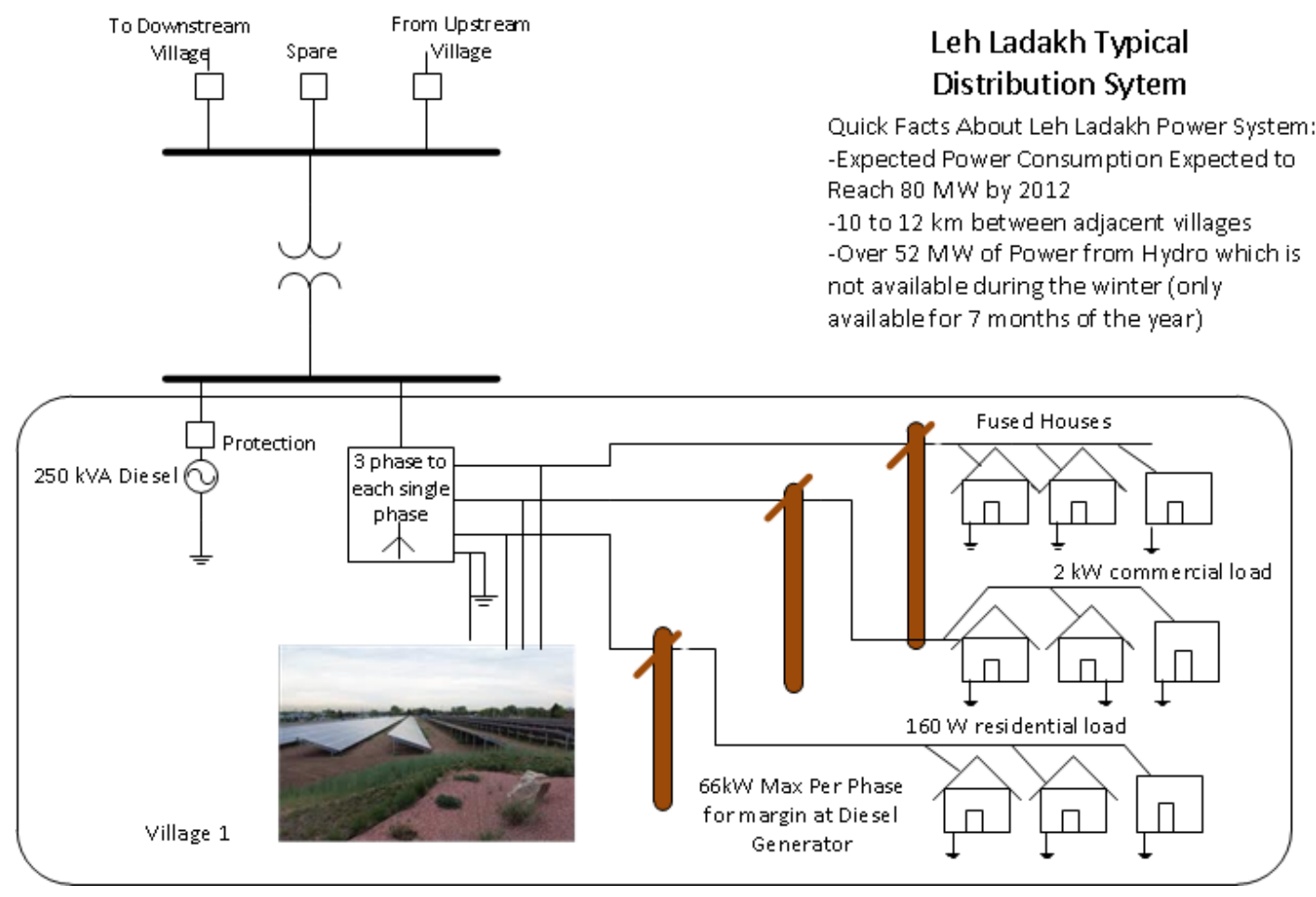

Figure 8. Possible Leh Ladakh technical configuration

In a partially electrified village (like the one shown in the figure above), solar PV can replace existing diesel generators or augment the energy supply and can utilize existing T\&D infrastructure to provide energy to households and businesses.

Distribution in electrified towns and villages in Leh District is implemented by JKPDD. As illustrated in the figure above, the local diesel generators produce power at $415 \mathrm{~V}$, which are then stepped down via transformers to $240 \mathrm{~V}$ closer to clusters of homes. The village power grid generally uses steel tubular poles and locally grown deodar wood poles (SP 13, SP 15, and SP $31)$ to carry the insulated lines to the customers. The solar PV project will need to be interconnected to the existing grid at $415 \mathrm{~V}$.

Unelectrified villages would have the additional cost of T\&D infrastructure. Table 7 below provides a breakdown of the costs in Leh District. Minigrid projects could greatly benefit from subsidies for building distribution networks. Currently, there are such subsidies provided under RGGVY for rural electrification. 
Table 7. Cost of T\&D Infrastructure

\begin{tabular}{|l|l|l|}
\hline Item of Work & Unit & Unit Cost (millions Rs) \\
\hline Construction of 11/33-kV grid station & Nos. & 27.6 \\
\hline $\begin{array}{l}\text { Construction of three 33/11-kV receiving } \\
\text { stations }\end{array}$ & Nos. & 28.9 \\
\hline Construction of 33-kV line & $\mathrm{km}$ & 2.7 \\
\hline $\begin{array}{l}\text { Cost of 11-kV OH line for connecting 11- } \\
\text { kV feeders from grid station to existing } \\
\text { 11-Kv line on weasel conductor }\end{array}$ & $\mathrm{km}$ & 0.5 \\
\hline
\end{tabular}

\section{Source: LREDA}

The main reason for selecting a $250-\mathrm{kW}$ system for the technical configuration is because the JNNSM subsidy for minigrids is capped at that level. The actual system size or the number of $250-\mathrm{kW}$ systems required for a village would depend on a number of factors, including demand for power and number of households and commercial establishments. Capping each individual system at $250 \mathrm{~kW}$ will allow developers who are, for example building a total of $1 \mathrm{MW}$ to take advantage of the JNNSM subsidy by building four separate $250-\mathrm{kW}$ systems.

Additionally, several adjoining villages with their own individual minigrids could be connected through $66 \mathrm{kV}$ lines (shown in Figure 9 below in yellow). LREDA has already sanctioned the construction of a $33-\mathrm{kV}$ line along the longer yellow line on the map. It is possible that some of the adjoining villages located closer than five miles can be connected along a 33-kV line.

Contractors that build generators choose sites to build based on whether there are loads nearby to use the power. Since only a few of the villages are connected, villages that are close geographically and have flat terrain for installing distribution poles should have distribution installed to the large hydro generators. Interconnecting multiple villages will make it easier for developers to interconnect renewable energy projects. A larger, interconnected power system increases reliability and geographic dispersion of solar resources, reduces their variability, and therefore increases reliability of the system as a whole.

Smart grids and net metering can be implemented for such systems, especially if there is variation in commercial and residential loads where peak energy use might differ. Backup power through energy storage and diesel generators can also be sized more efficiently. 


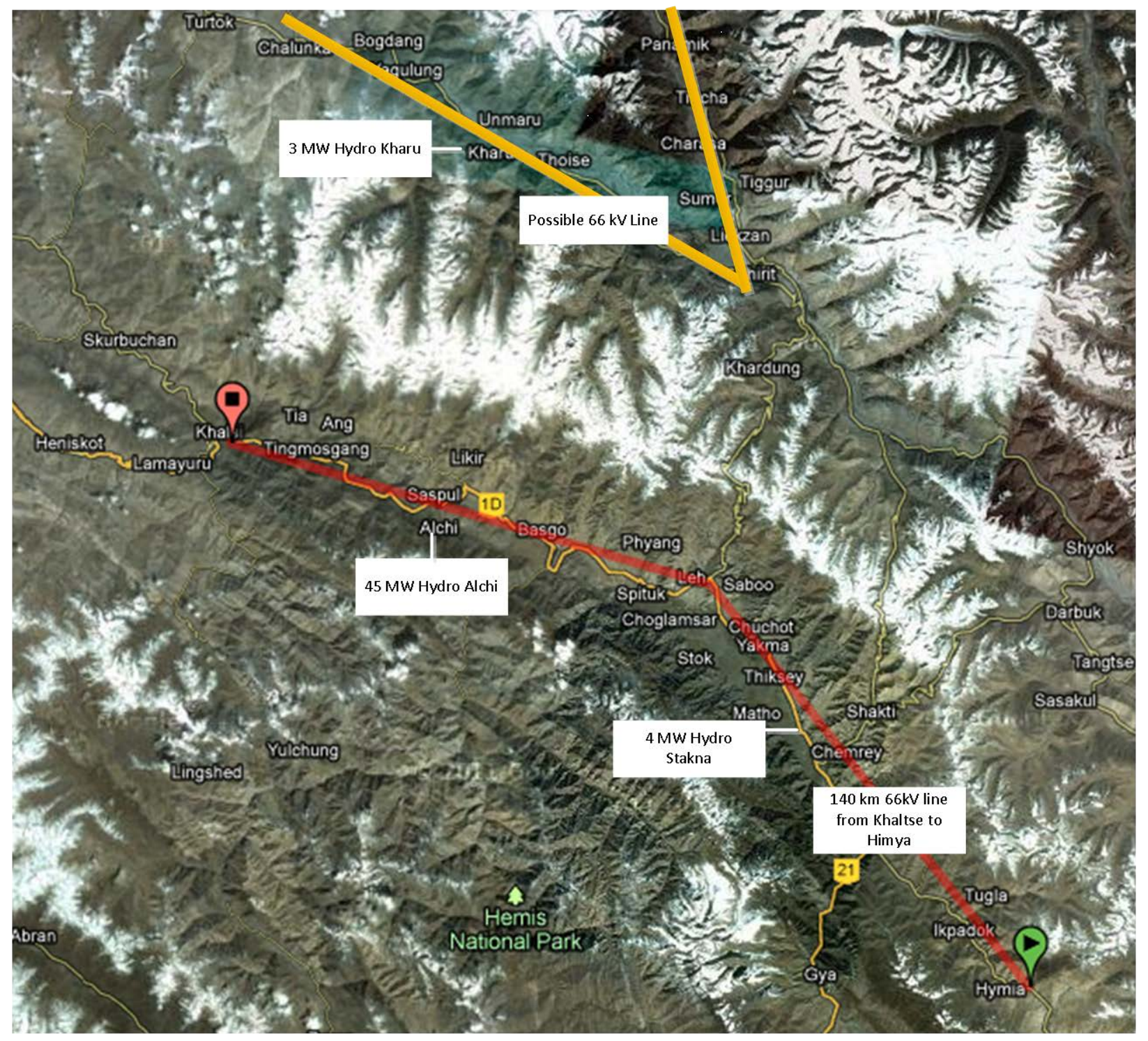

Figure 9. Leh-Ladakh 66-kV lines and hydro generation

Source: Google Maps, illustration adapted by Daniel Martin, NREL

Smart grid technologies can also be used to improve the performance and help monitor the overall system for maintenance. The electrical line, along with diesel generators, can be monitored remotely to detect issues and give an alarm if maintenance is needed. The remote control of the diesel can ramp down its output when the PV is increasing its output. The PV and energy storage can also be monitored and controlled remotely to provide voltage and frequency control at the site. Overall, smart grid technologies enable self-awareness of what is happening on the power system, as well as more optimized management of resources through monitoring and control. 


\subsubsection{Sizing Energy Storage}

Many types of batteries exist for grid-connected applications. Lead-acid batteries are a mature technology and have a lower cost compared to other technologies. They do have some disadvantages due to their shorter life (1,000 charge/discharge cycles) and the toxic materials used in manufacturing. Lithium-ion batteries have a higher energy density and a longer life (1,200-3,000 charge/discharge cycles) but can be more expensive compared to lead-acid batteries. Sodium sulfur batteries have also been used for grid-connected energy storage applications, but they require high temperatures $\left(320^{\circ} \mathrm{C}\right)$. Good candidates for Leh District are lead-acid or lithium-ion batteries. There are currently no indigenous manufacturers of lithium-ion battery technologies in India. Unless imported, lead-acid batteries are the only option. ${ }^{21}$

For a system with just PV and energy storage, the most economical way to size energy storage would be to choose a PV size so that the energy stored in the battery during an average day will equal the energy required for use at night. A $250-\mathrm{kW}$ PV array, for example, in Leh District can be used with energy storage to generate a constant $60-\mathrm{kW}$ output. The energy storage should therefore be sized for 1.2 MWh of storage and $200 \mathrm{~kW}$ power rating. Figure 10 below shows the operation of the battery for a constant $60-\mathrm{kW}$ output with PV generation. The battery will provide 1,200 kWh of energy at night, and the PV system will produce an excess of 1,200 kWh of energy during the day to charge the battery. According to LREDA, battery sizing and capacity for current projects based on an analysis of the number of "sunny days" per year provides two days of autonomous power.

The energy provided to the battery during the day should equal the energy used at night for the energy storage to be economical. It would not be economical to provide energy storage for a year at a site without charging it. ${ }^{22}$

${ }^{21}$ Currently, Gel, AGM, and Flood Type LMLA batteries are used at power plants. The topographical conditions in Ladakh and cold desert-like environment have an inverse effect on the life of the battery. Therefore, construction of battery storage rooms is necessary and could add to the cost of setting up SPV power plants.

${ }^{22}$ Batteries for current projects in Ladakh have been sized to provide two days of autonomous power. Though cost is an important factor, consideration of the capacity of the power plant with respect to transportability of the system components, type of terrain, and availability of land near existing transmission and distribution infrastructure all play a large role in determining the most economical sizing for the power plant. 


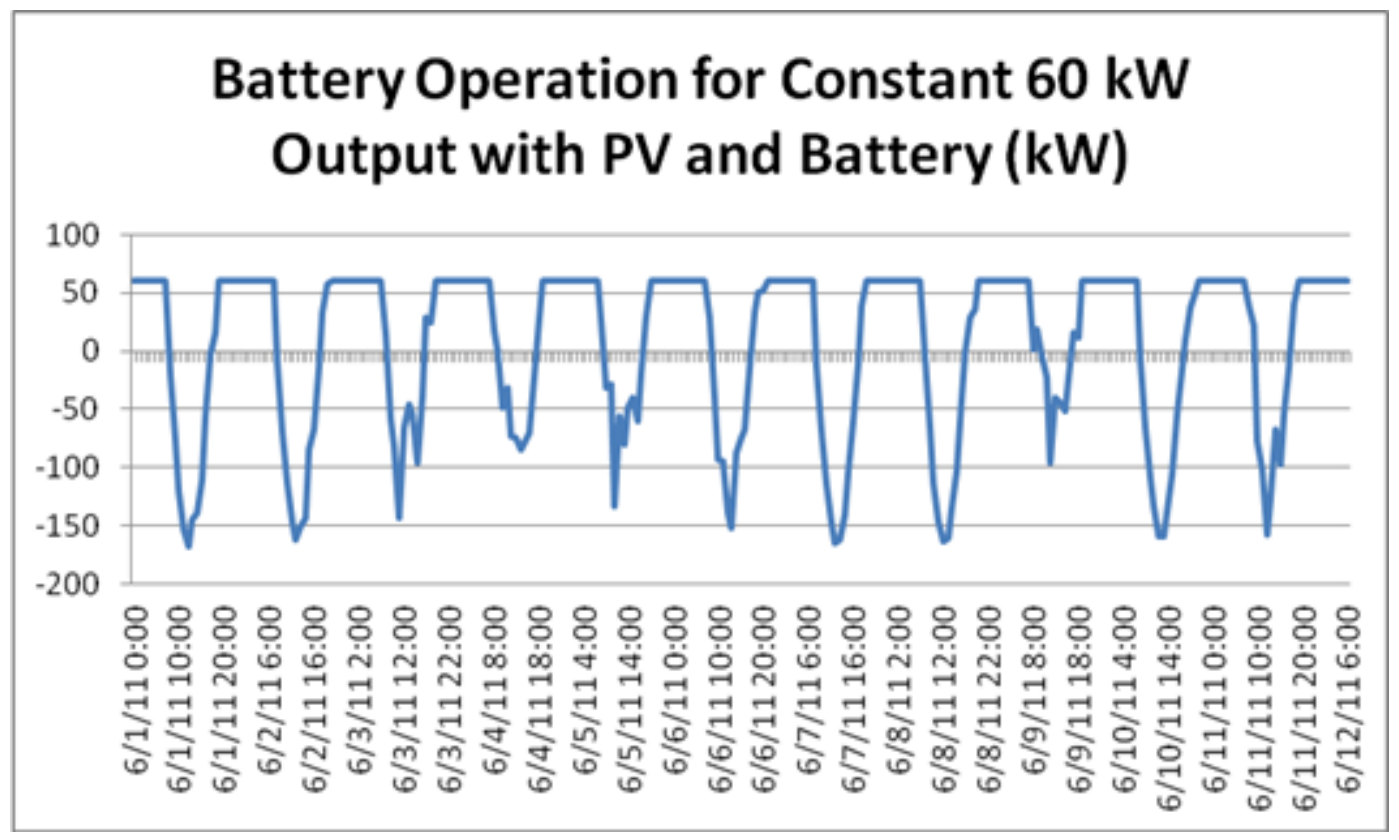

Figure 10. Typical battery operation for constant $60-\mathrm{kW}$ output

To illustrate the issue of charging the battery during the day for output at night, $75 \mathrm{~kW}$ of constant power is chosen in Figure 11. The PV is still producing rated $250 \mathrm{~kW}$ output. The energy used at night is $1.1 \mathrm{MWh}$, and the excess energy produced during the day for charging is only $500 \mathrm{kWh}$. The battery will become completely discharged within a short time. When the battery is completely discharged, it cannot provide power to the site.

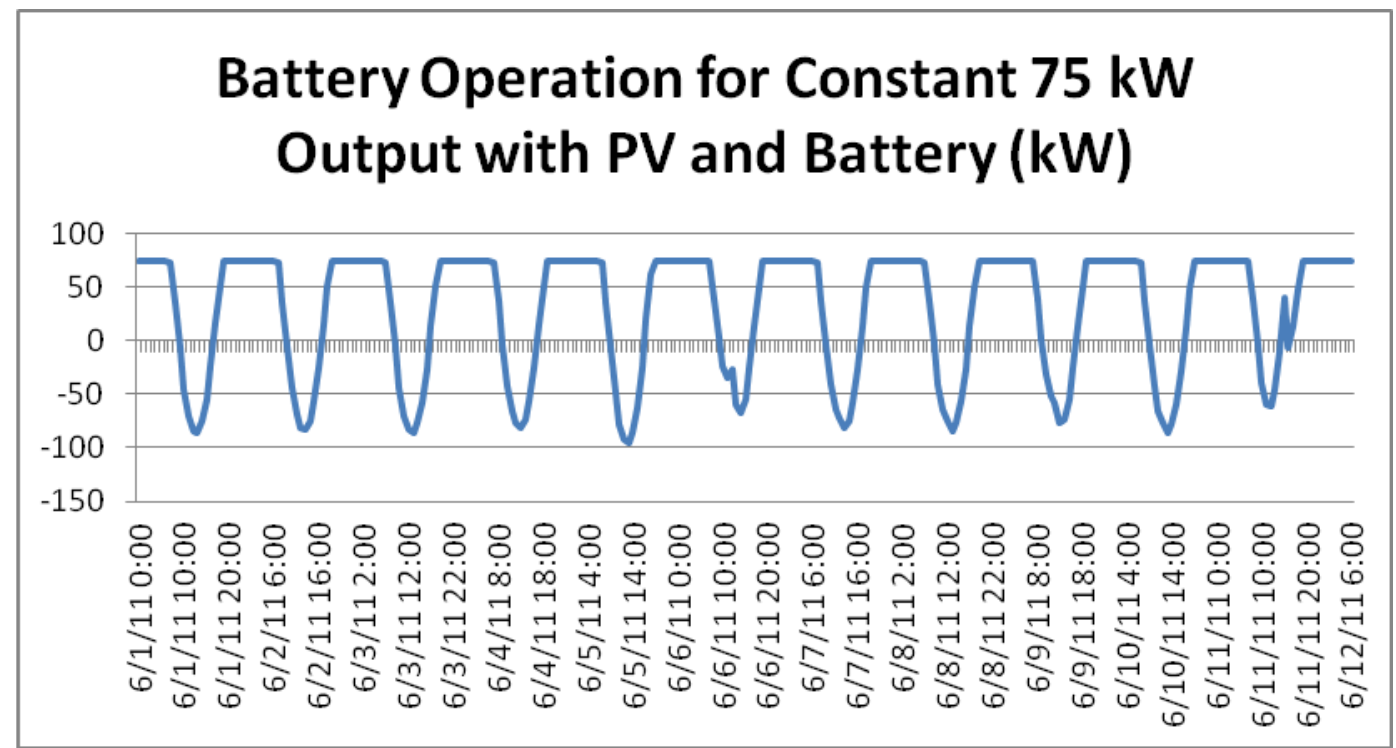

Figure 11. Typical battery operation for constant $75-\mathrm{kW}$ output

The last case considered is increasing the PV output between multiple sites so a constant $250 \mathrm{~kW}$ can be provided for an average day, as shown in Figure 12 below. Based on the solar resource data available, 1.5 MW of PV would need to be installed over six sites of $250 \mathrm{~kW}$ rated output, 
all connected with an electrical line. The energy storage should be sized to discharge the same amount of energy at night as is charged during the day. The energy storage will provide 3.5 MWh of energy during the night, and the PV will provide in excess of 3.5 MWh of energy to charge the energy storage. The energy storage should be sized for $4 \mathrm{MWh}$ of energy rating and $1.25 \mathrm{MW}$ of power. This case does not require additional diesel generation for a constant 250$\mathrm{kW}$ power output as long as the energy storage can provide the proper controls to maintain voltage and frequency to the system.

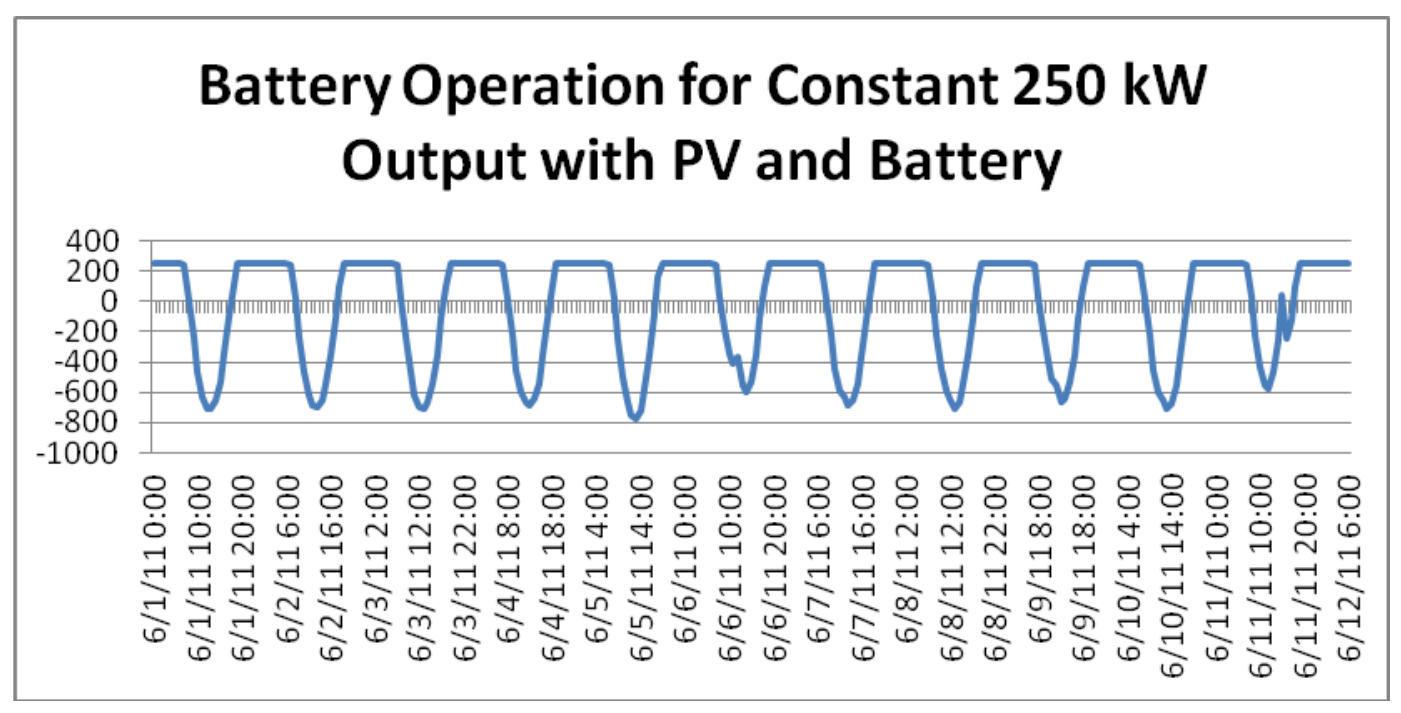

Figure 12. Typical battery operation for constant 250-kW output

Another important point to note is that an energy storage device will have a limit to the amount of energy that can be stored. After the energy storage is fully charged, the device cannot charge anymore and will be forced to turn off or start discharging. The same is true while discharging. Once the energy storage discharges its capacity, the device cannot discharge anymore and must turn off or start charging. On days with maximum irradiance, the energy storage will likely become fully charged and will be forced to turn off. Additionally, on days when there is minimum irradiance, the energy storage may become fully discharged and be forced to turn off. During these days, the control scheme between the PV and diesel need to be adjusted to maintain power quality (voltage and frequency thresholds, etc.) during transience due to the intermittency of solar.

\subsection{Solar Generation Required to Meet Demand in Leh District}

The district of Leh is in a very unique situation. By the end of 2014, the total installed capacity is expected to be approximately $80 \mathrm{MW}$, and the demand is expected to be $107 \mathrm{MW}$. As discussed earlier, much of this demand will be met through building several hydro projects. And since hydro is only partially operational in the winter, this means that the effective installed capacity will be just $31.85 \mathrm{MW}$ during winter.

Building just enough solar to meet demand in the summer would require the implementation of $28 \mathrm{MW}$ of solar, to augment the existing 15.2 MW of diesel, $62.1 \mathrm{MW}$ of hydro, and 1.7 MW of 
solar. Under this scenario, Leh District would have a deficit of $47 \mathrm{MW}$ in installed capacity during the winter. The gray area in Figure 13 below illustrates this deficit.

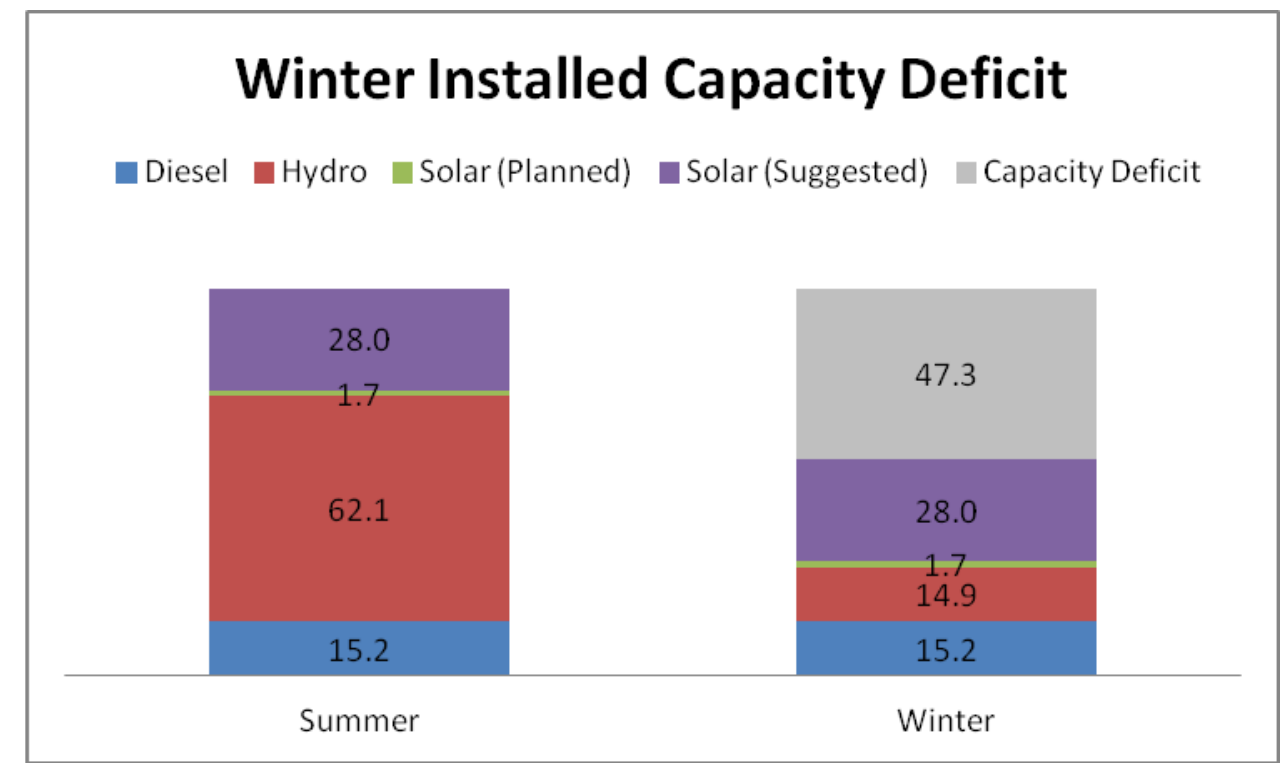

Figure 13. Winter installed capacity (in MW) deficit

Building enough solar to meet demand in the winter would require the implementation of 75.3 MW of solar to augment the existing 15.2 MW of diesel, 14.9 MW of hydro, and 1.7 MW of solar. Under this scenario, Leh District will have an excess $47.3 \mathrm{MW}$ in solar capacity during the summer months when hydro is operational. The gray area illustrates surplus capacity in Figure 14 .

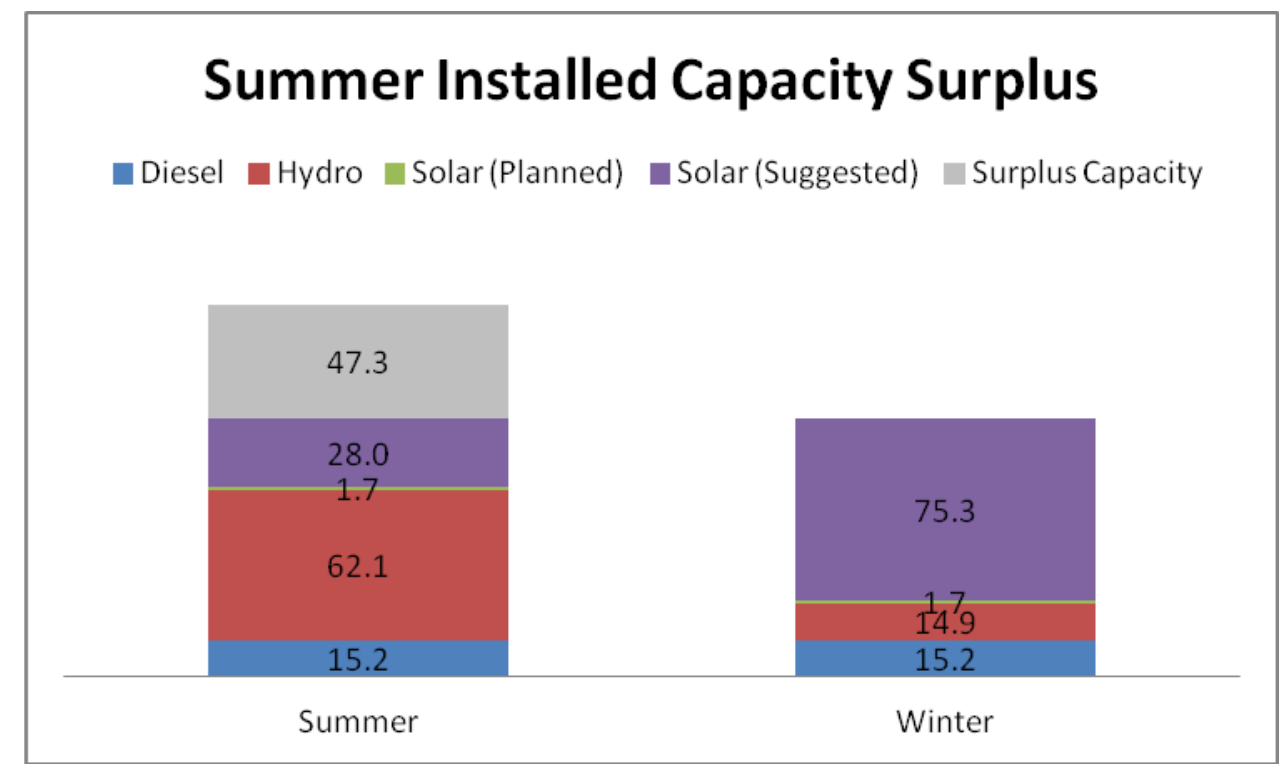

Figure 14. Summer installed capacity (in MW) surplus 
Considering all the challenges, there are a couple of different options for how Leh District can schedule the summer/winter generation; however, each presents a specific set of challenges. Further research and analysis will be required to determine their viability:

- Option 1: Scheduling diesel generation for just the winter months could present a more reasonable, but not optimal, solution for Leh District. For example, running just hydro during the summer months and meeting the rest of the demand with solar would require the construction of $44.9 \mathrm{MW}$ of solar. Not using diesel in the summer will save on fuel costs. During the winter months, the existing diesel generation of 15.2 MW and 14.9 MW of hydro can augment the solar capacity for a total of $75 \mathrm{MW}$ of generation, bringing the deficit in generation capacity to $32 \mathrm{MW}$. This solution is illustrated in Figure 15 below. Building up to $44.9 \mathrm{MW}$ of solar would require the construction of nearly $180250-\mathrm{kW}$ systems. For each of these, the energy storage will need to be sized for $1.2 \mathrm{MWh}$ of energy and $200 \mathrm{~kW}$ of power in order to have a constant output of $60 \mathrm{~kW}$.

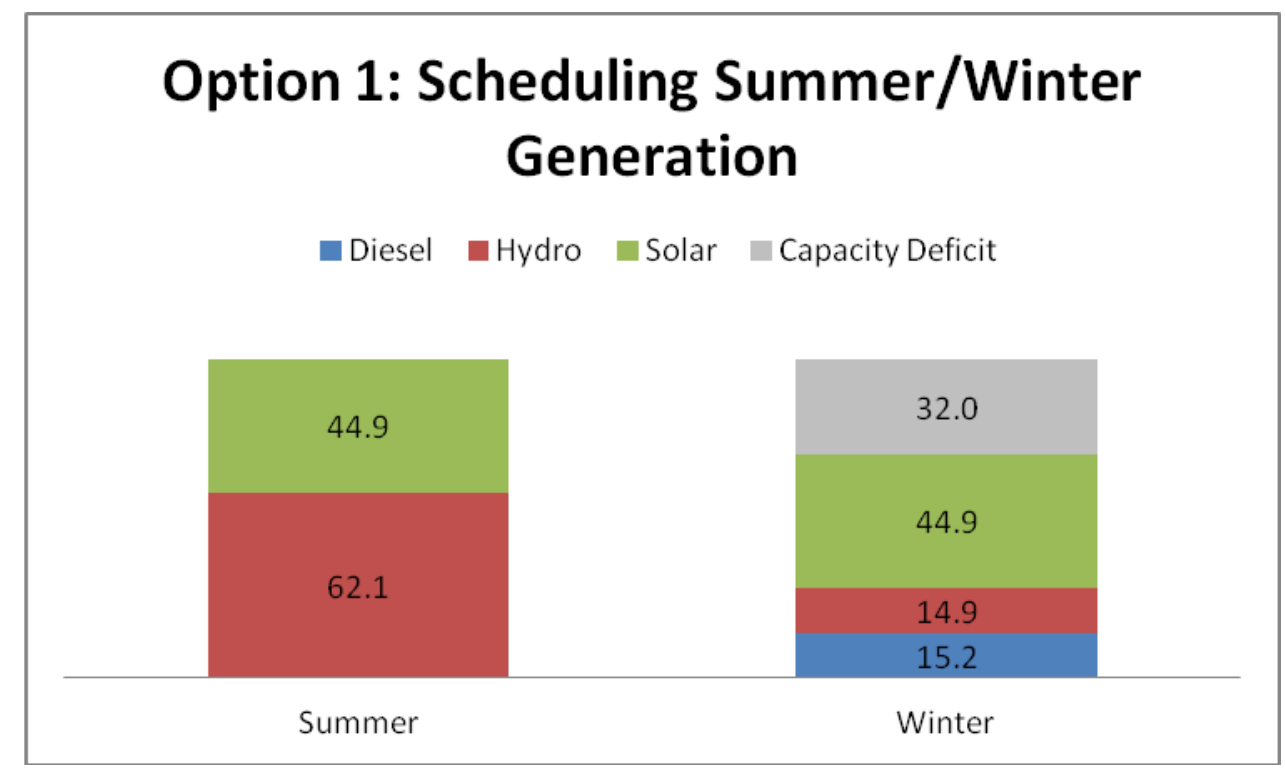

Figure 15. Option 1: scheduling summer/winter (in MW) generation

- Option 2: Hydro plants can be upgraded for use as pumped storage, which can replace the use of hydro during the day. Under this scenario, Leh District could build 75.3 MW of solar capacity to meet the full winter demand. This proposed solution is illustrated in Figure 16, which shows a maximum required pumped storage capacity of $30.1 \mathrm{MW}$. Upgrading hydro for pumped storage will require installation of new equipment, including pumps and generators and more technical analysis. During the day, while PV is producing electricity, water could be pumped upstream and stored for release at night after the PV goes offline to provide 30.1 MW of capacity during the summer and 14.9 MW during the winter. The existing diesel generators can provide the additional needed capacity of 15.2 MW in the winter months. The batteries for PV would still be sized appropriately to satisfy winter demand, but during the summer, the battery can provide 
frequency and voltage regulation for solar and hydropower. Building up to 75.3 MW of solar would require the construction of $301250-\mathrm{kW}$ systems. For each of these, the energy storage will need to be sized for $1.2 \mathrm{MWh}$ of energy and $200 \mathrm{~kW}$ of power, in order to have a constant output of $60 \mathrm{~kW}$.

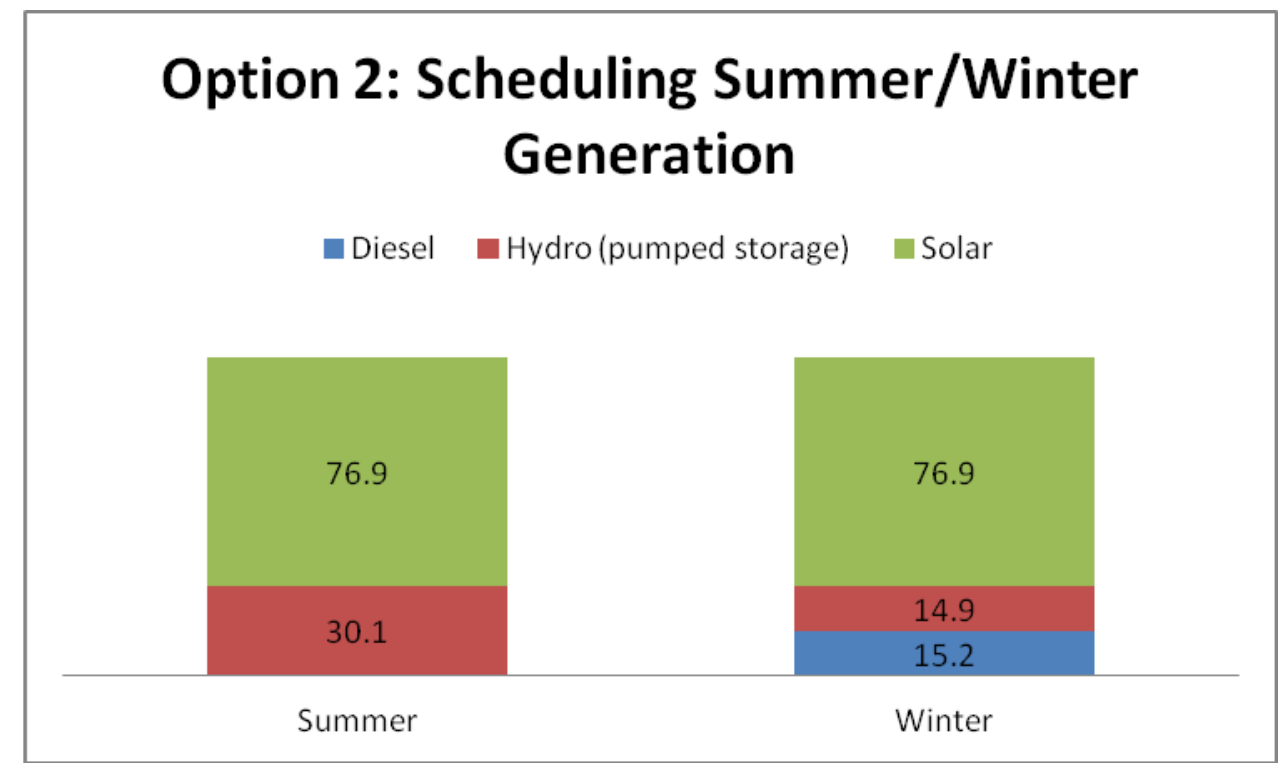

Figure 16. Option 2: scheduling summer/winter generation (in MW)

\subsection{Technical Considerations Prior to Implementation}

Before installing new generation equipment, it is necessary to determine whether the lines and distribution equipment are sufficiently rated to handle new generation. An equipment rating and load flow study should be done to determine that. It is important to protect the investment of generation and new distribution equipment through a protection and coordination study, a short circuit analysis, and a voltage drop study.

Diesel generators operate in a master mode (or sochronous mode) in minigrids, where the generator will automatically adjust output to match the load. A stability study should be done to determine what problems may occur when paralleling two or more existing diesel generators, in the case of interconnecting minigrids. A single diesel generator or a group of diesel generators in a minigrid operate in isochronous mode or load sharing isochronous mode respectively, maintaining the frequency of the system at a desired value. If two or more single generators or a group of generators in isochronous mode between two or more minigrids are paralleled together, they can each try to control frequency.

Since frequency can vary over an electric system, the situation described can create an unstable condition where one generator or group of generators will ramp up and the rest will ramp down their output or even turn off. The control of diesel generators in isochronous mode should be changed if paralleled with other diesel generators in isochronous mode also. A possibility to interconnect minigrids with existing diesel generators is to have only the largest gen sets in one of the minigrids operating in isochronous load sharing mode and the rest of the diesels operating in base load mode. Another possibility is to have all of the generators operating in droop control. In any case, it is likely that generator controls will have to be changed when interconnecting 
minigrids, and such change may be from simply modifying the existing load control of the generator to adding expensive control equipment. Diesel generators may already be operating in parallel so the generators already have their controllers set to operate in parallel. In some cases, retrofitting an existing generator may not be cost effective, and retiring or using it for other applications such as backup power may be more cost effective. Diesel generators could also be used as a backup generator with a transfer switch for critical loads (hospitals, etc.). Acquiring one or more new large generators to interconnect minigrids may be required in some cases rather than retrofitting existing diesel generators with inadequate load controls.

A stability study should also be done to show that the variability in the solar photovoltaic output will not cause issues and show the limits on the amount of PV that can be added. As the diesel generation is replaced with solar and energy storage, the energy storage control method needs to be able to maintain voltage and frequency. As solar irradiance changes or as loads change, the energy storage needs to have fast voltage and frequency control to maintain system stability.

The improved infrastructure that will prepare villages to be interconnected is a transformer to step down the $11-\mathrm{kV}, 33-\mathrm{kV}$, or $66-\mathrm{kV}$ lines down to $415 \mathrm{~V}$ to be used by the village. There should be an interconnection point installed for an outgoing line to go to a village farther away from the hydro generators, and an incoming line from the hydro generators. A spare line may be installed also. Each line should be rated for the expected generation capacity, and protection equipment should be installed to protect and safely operate the electrical system. The protection equipment should be allowed to handle bidirectional flow of power. Increasing distribution capacity will allow for solar PV projects to be installed at locations where it may cost less to install PV or the regulations are easier to meet.

An issue when adding single-phase PV generation is that the single-phase systems can create an imbalance in the village distribution system. This can cause a large neutral current, which can be dangerous. The voltage can go out of range on one of the phases, causing protection devices to trip. The PV generation can also cause the diesel generators to go out of their normal operating range. If a diesel generator goes out of its operating range, it can trip, run inefficiently, or damage the generator.

Finally, there are some institutional barriers that may limit the grid development. The equipment owners should ensure that the equipment is being maintained by trained personnel. Currently, the human resources for the projects are developed through a five-year operations and maintenance contract to the solar and hydro project contractors. At least two local villagers are trained for the O\&M of the generation systems. LREDA is in the process of forming cooperative societies, which will include village leaders, LREDA staff, block development officers, and members of the Ladakh Autonomous Development Council, to appoint operators for the LREDA generation projects. 


\section{Business Case Analysis}

\subsection{Overview}

The objective of this business case analysis is to show at a very high level the economics of building 250-kW solar minigrids in Leh District. There are two different analyses presented in this section. The first is to determine the project economics or the cost to developers in implementing solar minigrids with an assumed internal rate of return of $20 \%$. The second analysis determines the cost to users of electricity from the minigrid and how that compares to the cost of diesel and hydro generation. The information presented in this section is based on rough estimates and will require further analysis and verification to ensure accuracy.

\subsection{Project Economic Analysis}

The first analysis contains four scenarios. The first two consider the development of PV minigrids by the state nodal agency in normal regions of India and in special-category states such as Jammu \& Kashmir, where JNNSM subsidies are high. The next two consider the development of PV systems by private developers in normal areas and in special-category locations.

\subsubsection{Scenarios 1 and 2: State Nodal Agency as Developer in Normal Rural Area and in Remote Locations}

In the first two scenarios, the SNAs are the sponsors of the solar PV projects. For more information on the process for how SNAs develop projects, please refer to Section 2.3. In both cases, the SNA owns the projects, and solar developers will need to recover their investment by year five and train individuals within the village to operate and maintain the plant starting in year six until end of life. This will include replacing the battery roughly once in eight years. The main difference between the first and second scenario is the MNRE incentive levels available to SNAs that are located in normal rural areas of India versus those located in special-category regions. However, in both cases the developer will be given $95 \%$ of the subsidy amount over the course of the first two years. Therefore, the rate charged to consumers in both scenarios will be the same.

According to our analysis, the solar developer's unlevered internal rate of return (IRR) of $20 \%$ can be met with a solar rate of Rs. $7.7 / \mathrm{kWh}$ (US\$0.154/kWh). The assumptions and results of our model are shown in Table 8 below. The developer's return has been calculated over a period of five years, at which point full control of the project is turned over to the village cooperative community and the SNA. 
Table 8. Scenarios 1 and 2: State Nodal Agency Develops PV Project

\begin{tabular}{|c|c|c|c|}
\hline Revenue & & Production Data & (kWh) \\
\hline \multirow[t]{3}{*}{ Base PPA price (INR/kWh) } & INR 7.70 & January & 17,687 \\
\hline & & February & 27,603 \\
\hline & & March & 40,633 \\
\hline \multicolumn{2}{|c|}{ Total Central and State Government Incentive } & April & 39,972 \\
\hline Central government subsidy & $\begin{array}{l}30 \% \text { in normal regions } \\
\text { and } 90 \% \text { in special- } \\
\text { category regions }\end{array}$ & May & 39,504 \\
\hline \multirow[t]{2}{*}{ State nodal agency } & $\begin{array}{l}70 \% \text { in normal regions } \\
\text { and } 10 \% \text { in special- } \\
\text { category regions }\end{array}$ & June & 39,254 \\
\hline & & July & 36,544 \\
\hline \multicolumn{2}{|l|}{ Timeline of Subsidy Payment to Developer } & August & 37,88 \\
\hline Preconstruction payment & $50 \%$ & September & 39,296 \\
\hline Postconstruction payment & $45 \%$ & October & 42,841 \\
\hline \multirow[t]{3}{*}{ O\&M payment } & $1 \%$ a year for five years & November & 39,111 \\
\hline & & December & 27,405 \\
\hline & & Total & 427,738 \\
\hline \multicolumn{2}{|l|}{ Basic System Information } & $\operatorname{Tax}$ & \\
\hline System size (kW) & 250 & Depreciation schedule & $\begin{array}{c}\text { No depreciation assumed due to } \\
\text { full capital subsidy }\end{array}$ \\
\hline System life & 25 years & $\begin{array}{l}\text { Central gov't minimum } \\
\text { alt tax (MAT) for first } 10 \\
\text { years }\end{array}$ & $20 \%$ \\
\hline Developer investment recovery & Year five & $\begin{array}{l}\text { Central government } \\
\text { MAT for next } 15 \text { years }\end{array}$ & $33.40 \%$ \\
\hline Install cost/watt & INR 264 & & \\
\hline System cost & INR $59,000,000$ & & \\
\hline $\begin{array}{l}\text { Development costs (owner pre-/post- } \\
\text { construction costs) }\end{array}$ & INR 7,000,000 & & \\
\hline Capital Cost Summary (INR) & & Annual Operating Cost & \\
\hline Total direct capital costs & INR 56,000,000 & O\&M/billing /collection & INR 900,000 \\
\hline Panels \& equipment & INR 15,000,000 & Battery replacement & $\begin{array}{c}\text { Three times during project life at } \\
\text { cost of INR } 12,000,000\end{array}$ \\
\hline Panel costs per watt & INR 60.00 & Inverter replacement & $\begin{array}{l}\text { Once during project life at cost of } \\
\text { INR 2,500,000 }\end{array}$ \\
\hline Foundation & INR 4,000,000 & & \\
\hline Batteries & INR $12,000,000$ & Financial & \\
\hline Balance of plant & INR 3,500,000 & Developer IRR & $20 \%$ \\
\hline Indirect capital costs & INR $3,000,000$ & & \\
\hline Installation \& site work & INR $3,000,000$ & & \\
\hline Owner's costs & INR 7,000,000 & & \\
\hline Engineering, design \& development & INR 7,000,000 & & \\
\hline Other start-up costs & INR 0 & & \\
\hline Financing costs & INR 0 & & \\
\hline Total project costs & INR $66,000,000$ & & \\
\hline
\end{tabular}


As seen above, the model assumed an installed cost per watt of Rs. 264 (US\$5.28). According to the JNNSM guidelines, for 2011, the "benchmark price for photovoltaic systems with battery back-up is Rs. 270 per Watt." As mentioned earlier, there is a 90\% subsidy available in specialcategory states for the development of solar minigrids. Additionally, the state of Jammu \& Kashmir provides a subsidy for the remaining $10 \%$. The developer receives the subsidy from the nodal agency in a series of installments, as indicated in the table above. As shown in Figure 17 below, since the developer only receives the first $50 \%$ of the subsidy prior to construction in year zero, the developer must therefore contribute about Rs. 33 million (US\$660,000) up front to build the project. The developer receives $45 \%$ of the subsidy during year one and therefore has a positive cash flow that year. The rest of the $5 \%$ is received in installments of $1 \%$ every year for the first five years. There is no cost of debt assumed, since all of the capital costs are covered by the subsidy in the two years. The developer must recover the return on investment of $20 \%$ in the first five years.

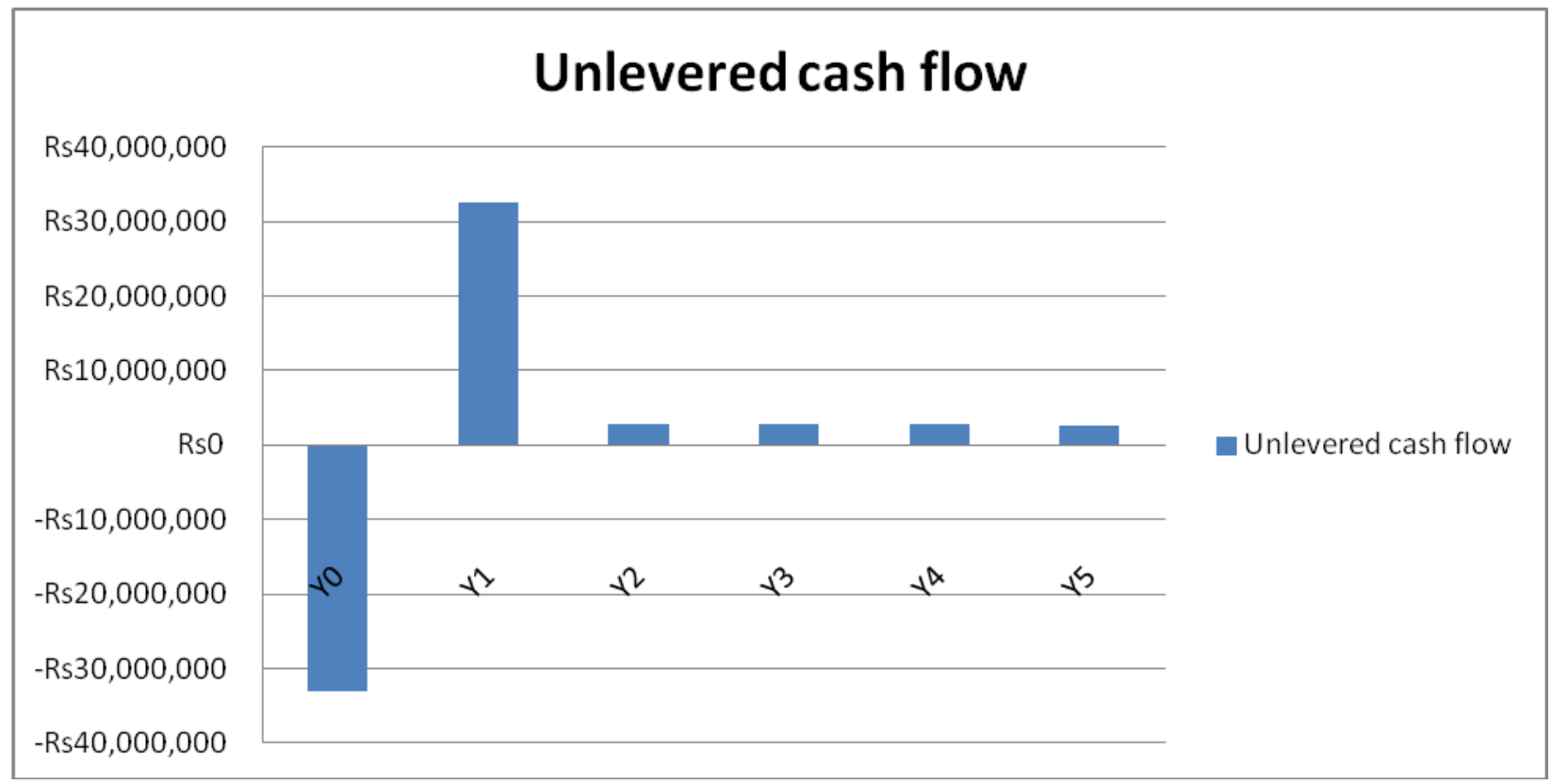

Figure 17. Five-year unlevered cash flow from project

The analysis above does not include any costs associated with building the T\&D infrastructure for the project. Unless there are other subsidies available, the cost of the project will increase.

\subsubsection{Scenarios 3 and 4: Private Developer Perspective in Rural India and Remote Locations}

In Scenario 3, a private developer owns and operates the project in a special-category state in India. The developer therefore qualifies for the $90 \%$ MNRE subsidy and contributes $10 \%$ of the remaining equity into the project. The developer is also responsible for the O\&M of the project over 25 years, including replacement of batteries once every eight years and replacement of the invertors around year 13. Under this scenario, the rate of power is Rs. $6.3 / \mathrm{kWh}$ (US\$0.126). Table 9 shows the results and assumptions used in the model. The main reason for the lower 
power rate in this scenario is that the developer has the full 25 years to recover the investment and meet the IRR, whereas in scenarios 1 and 2, the time period was much shorter.

Table 9. Scenario 3: Private Developer Develops PV Project in Special-Category States

\begin{tabular}{|c|c|c|c|}
\hline Revenue & & Production Data & (kWh) \\
\hline \multirow[t]{3}{*}{ Base PPA price (INR/kWh) } & INR 6.3 & January & 17,687 \\
\hline & & February & 27,603 \\
\hline & & March & 40,633 \\
\hline \multicolumn{2}{|c|}{ Total Central and State Government Incentive } & April & 39,972 \\
\hline Central government subsidy & $90 \%$ & May & 39,504 \\
\hline \multirow[t]{2}{*}{ State nodal agency } & None & June & 39,254 \\
\hline & & July & 36,544 \\
\hline \multicolumn{2}{|l|}{ Timeline of Subsidy Payment to Developer } & August & 37,88 \\
\hline Preconstruction payment & $70 \%$ & September & 39,296 \\
\hline Postconstruction payment & $30 \%$ & October & 42,841 \\
\hline \multirow[t]{3}{*}{ O\&M payment } & None & November & 39,111 \\
\hline & & December & 27,405 \\
\hline & & Total & 427,738 \\
\hline \multicolumn{2}{|l|}{ Basic System Information } & Tax & \\
\hline System size (kW) & 250 & Depreciation schedule & $\begin{array}{c}80 \% \text { accelerated depreciation on } \\
\text { the } 10 \% \text { equity contribution from } \\
\text { investor }\end{array}$ \\
\hline System life & 25 years & $\begin{array}{l}\text { Central gov't minimum } \\
\text { alt tax (MAT) for first } 10 \\
\text { years }\end{array}$ & $20 \%$ \\
\hline Developer investment recovery & Year 25 & $\begin{array}{l}\text { Central government } \\
\text { MAT for next } 15 \text { years }\end{array}$ & $33.40 \%$ \\
\hline Install cost/watt & INR 264 & & \\
\hline System cost & INR 59,000,000 & & \\
\hline $\begin{array}{l}\text { Development costs (owner pre-/post- } \\
\text { construction costs) }\end{array}$ & INR 7,000,000 & & \\
\hline Capital Cost Summary (INR) & & Annual Operating Cost & \\
\hline Total direct capital costs & INR 56,000,000 & O\&M/billing /collection & INR 900,000 \\
\hline Panels \& equipment & INR 15,000,000 & Battery replacement & $\begin{array}{c}\text { Three times during project life at } \\
\text { cost of INR } 12,000,000 \\
\end{array}$ \\
\hline Panel costs per watt & INR 60.00 & Inverter replacement & $\begin{array}{c}\text { Once during project life at cost of } \\
\text { INR } 2,500,000\end{array}$ \\
\hline Foundation & INR 4,000,000 & & \\
\hline Batteries & INR $12,000,000$ & Financial & \\
\hline Balance of plant & INR 3,500,000 & Developer IRR & $20 \%$ \\
\hline Indirect capital costs & INR $3,000,000$ & & \\
\hline Installation \& site work & INR 3,000,000 & & \\
\hline Owner's costs & INR 7,000,000 & & \\
\hline Engineering, design \& development & INR 7,000,000 & & \\
\hline Other start-up costs & INR 0 & & \\
\hline Financing costs & INR 0 & & \\
\hline Total project costs & INR 66,000,000 & & \\
\hline
\end{tabular}


Figure 18 below depicts the anticipated 25-year unlevered cash flow from the project. The negative cash flow shown in years 8,16 , and 24 is for battery replacement. The cash flow in year 13 is reduced due to inverter replacement. As in the previous two scenarios, the analysis above does not include any costs associated with building the T\&D infrastructure for the project. Unless there are other subsidies available, the cost of the project will increase.

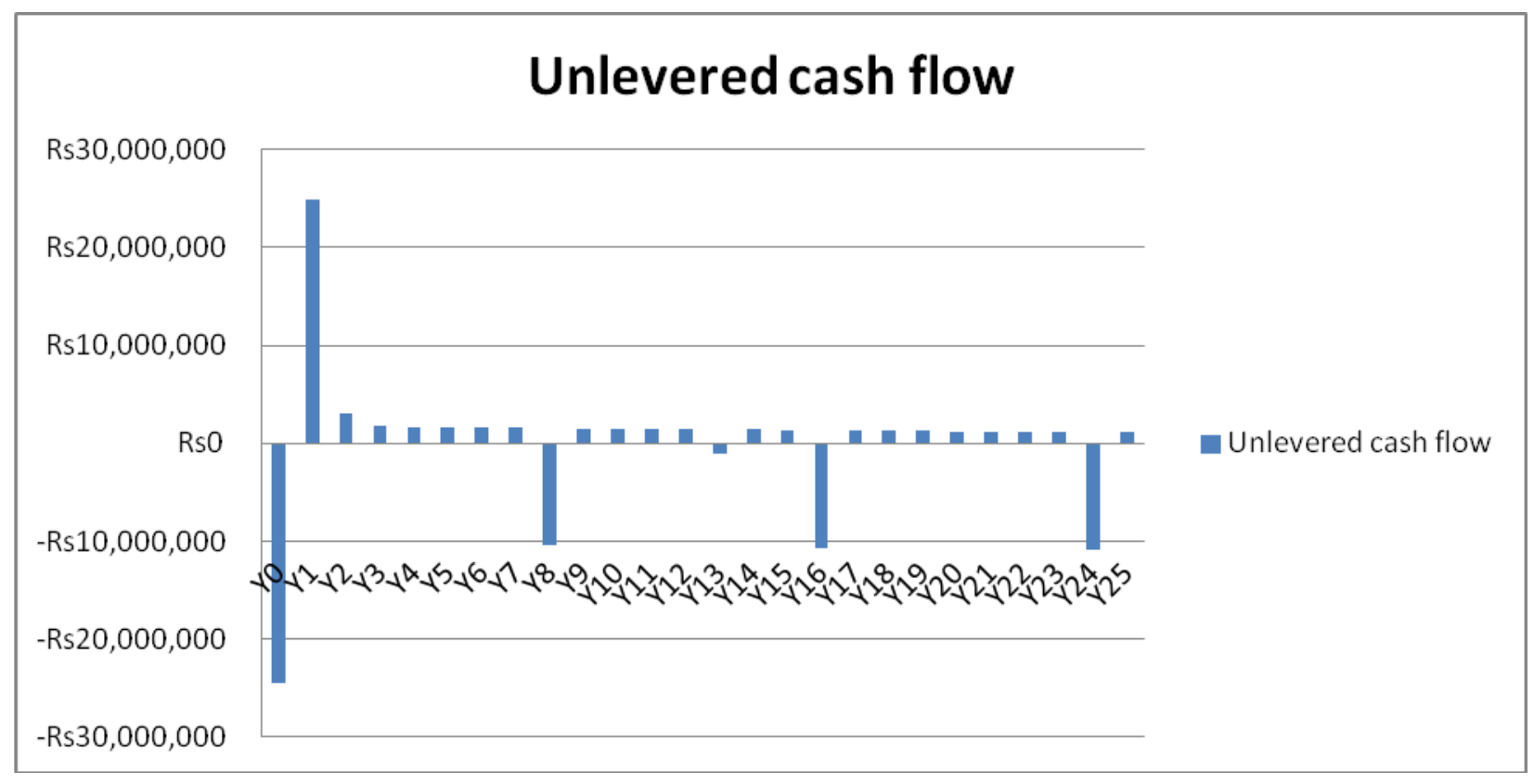

Figure 18. 25-year unlevered cash flow from project

The final scenario considers a private developer implementing a project in a normal rural region within India, where the capital subsidy is $30 \%$. The developer must then contribute minimum equity of $20 \%$, and the remaining amount can be financing through a low-interest loan from MNRE. However, to keep things consistent with other scenarios, the model assumes no debt but a capital contribution of $70 \%$ by the developer.

Under this scenario, the rate is calculated at Rs. 9/kWh (US\$0.18). Table 10 shows the results and assumptions used in the model. 
Table 10. Scenario 4: Private Developer Develops PV Project in Normal Rural Area

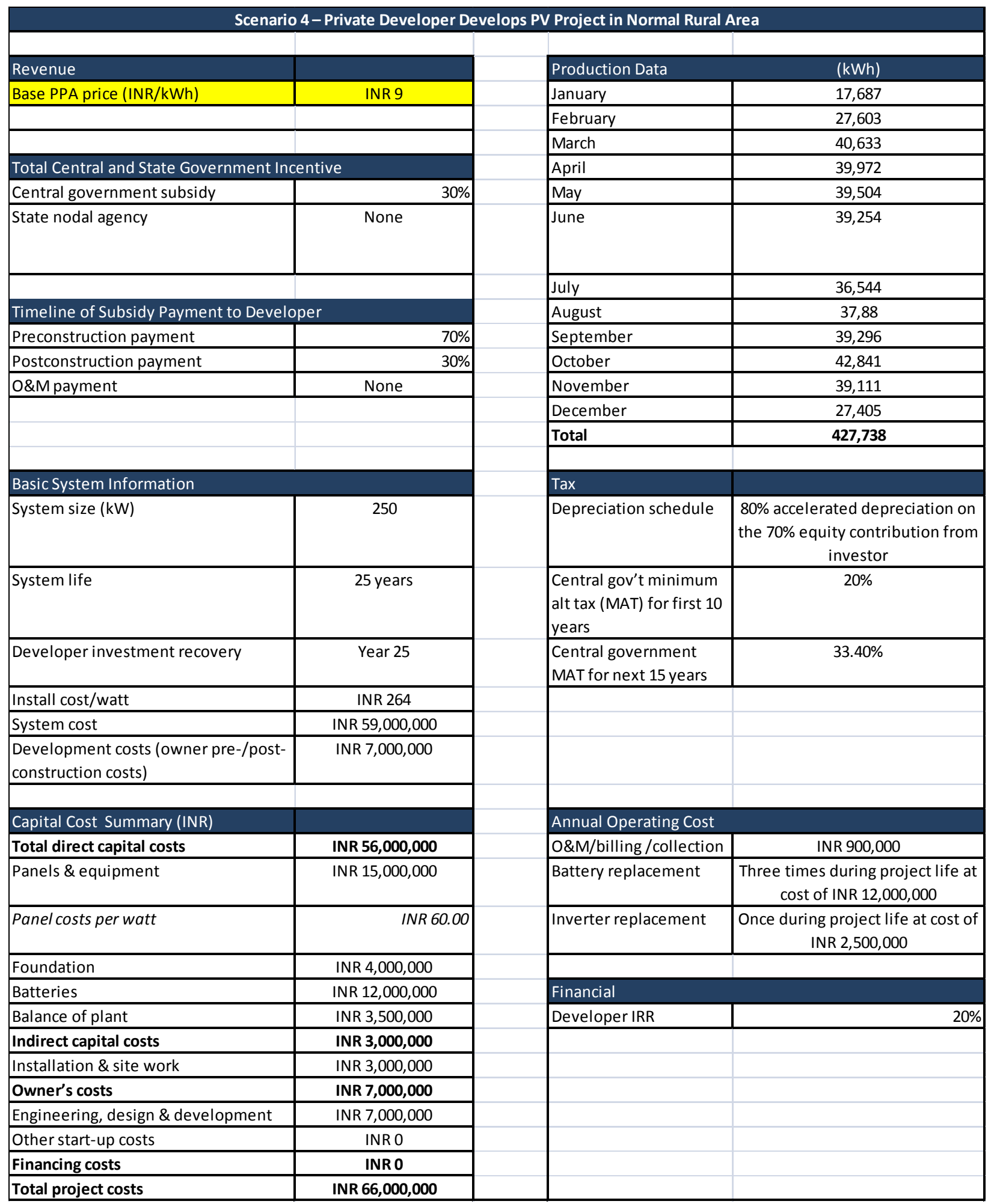


Figure 19 below illustrates the anticipated 25-year unlevered cash flow from the project. The negative cash flows again occur in years 8,16 , and 24 from battery replacement. As in the previous three scenarios, the analysis above does not include any costs associated with building the T\&D infrastructure for the project. Unless there are other subsidies available, the cost of the project will increase.

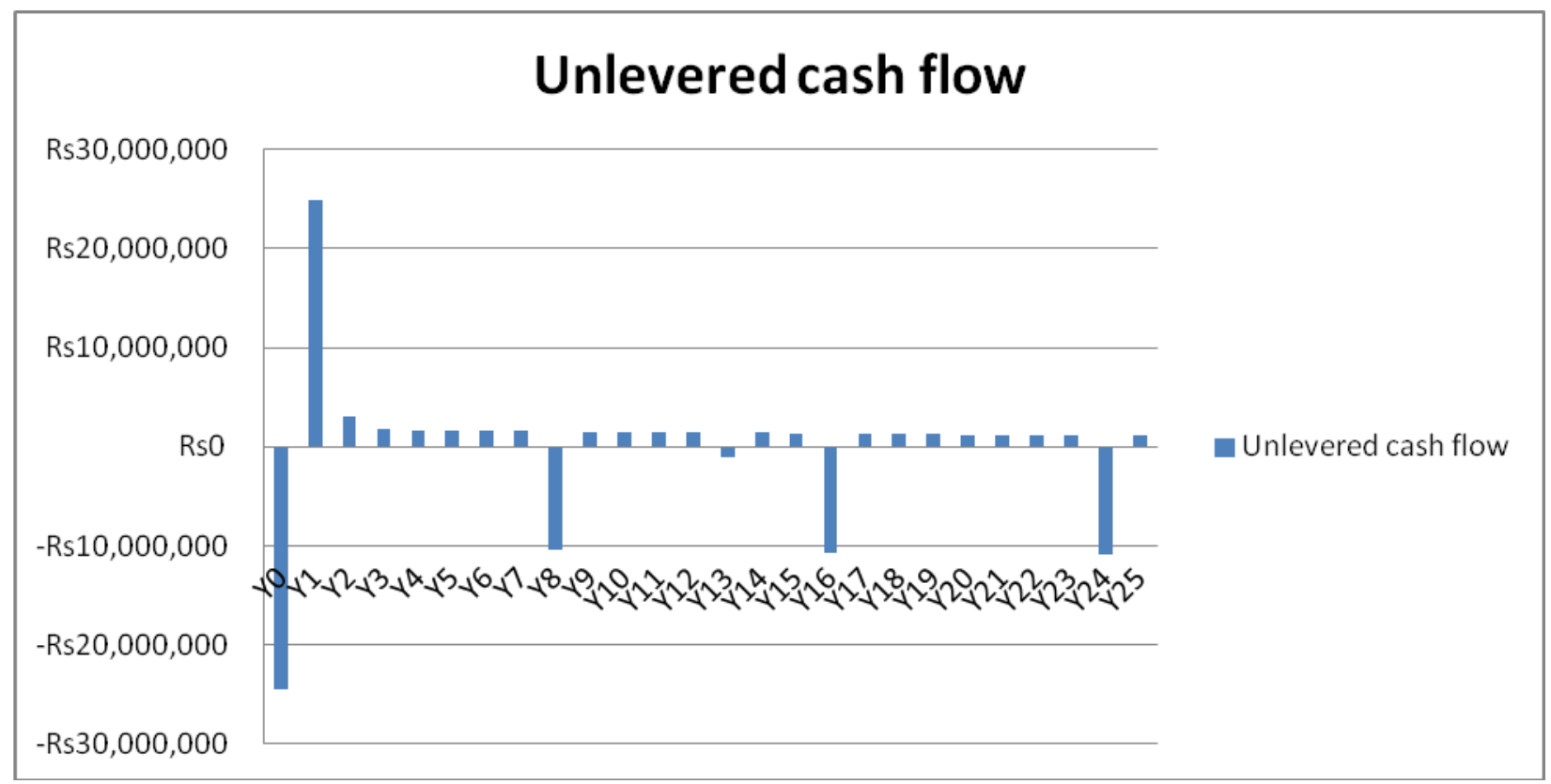

Figure 19. 25-year unlevered cash flow from project

There are several uncertainties and risks involved in the development of solar minigrid projects that can affect project performance. They include the following:

- Efficiency and quality of the solar panels impact how much electricity is actually produced.

- Differences in modeled estimates of solar resources versus solar insolation on the ground also impact amount of electricity produced.

- Battery replacement occurs on a faster timeline than what is projected, leading to higher project costs.

- Though cost is an important factor, the capacity of the power plant with respect to transportability of the system components, type of terrain, availability of land near existing transmission and distribution infrastructure, and type of battery also plays a large role in determining the most economical sizing for the power plant and battery storage. Currently, Gel, AGM, and flood type low-maintenance lead acid (LMLA) batteries are used at the power plants. The cold desert environment of Ladakh has an inverse effect on battery storage life; therefore, construction of passive solar buildings as battery storage rooms, especially in the case of LMLA batteries, is an added cost in setting up SPV power plants and can impact the cost of power in specific areas. 


\subsection{Customer Rate Comparison}

When the cost of solar power is compared to that of diesel and hydro, solar is a cheaper alternative to diesel in all four scenarios, and in some instances it might be a cheaper alternative to hydro. The cost of diesel power ranges from Rs. $12 / \mathrm{kWh}$ to Rs. $67 / \mathrm{kWh}$, and hydro is expected to be in the range of Rs. $3 \mathrm{kWh}-10 / \mathrm{kWh}$. The individual calculations are provided in the sections below.

\subsubsection{Diesel}

For diesel, the cost of installation is dependent largely on the $\mathrm{kW}$ or $\mathrm{kVA}$ rating of the diesel generator and will differ between villages as the power demand varies. According to LREDA, installation and commissioning of diesel generators in Ladakh cost approximately Rs. 16,000 per $\mathrm{kW}$. Tables 11 and 12 below serve as reference point for the all-inclusive running costs of 10 $\mathrm{kVA}$ and $900 \mathrm{kVA}$ diesel generators.

Table 11. 10-kVA Generator (8 kW $)^{23}$

\begin{tabular}{|l|l|l|l|l|}
\hline Particular & $\begin{array}{l}\text { Consumption per } \\
\text { Hour }\end{array}$ & $\begin{array}{l}\text { Consumption per } \\
\text { Year }\end{array}$ & $\begin{array}{l}\text { Cost per Unit } \\
\text { (Rs.) }\end{array}$ & $\begin{array}{l}\text { Amount Per Year } \\
\text { (Rs.) }\end{array}$ \\
\hline Diesel (HSD) & 2 liters & 8,640 liters & 46.34 per liter $^{24}$ & $4,003,778$ \\
\hline Mobil-Oil & & 150 liters & 145.00 per liter & 21,750 \\
\hline O\&M & & & & 86,000 \\
\hline TOTAL & & & & $\mathbf{4 , 1 1 1 , 5 2 8}$ \\
\hline
\end{tabular}

Source: LREDA

The total $\mathrm{kWh}$ output of an $8-\mathrm{kW}$ system is approximated at 63,072 , assuming a $90 \%{ }^{25}$ capacity factor. This can be further reduced to about $82 \%$ due to the elevation of $11,800 \mathrm{ft}$ above sea level. Due to lower oxygen levels, combustion is reduced. The total cost of power is therefore Rs. $65 / \mathrm{kWh}$ (US\$1.30/kWh). When the cost of installation and commissioning is added, the cost is approximately Rs. $67 / \mathrm{kWh}$ (US\$1.34/kWh).

23 Cost of 10-kVA diesel generator: installation and commissioning - approximately Rs. 128,000

24 Diesel fuel for the operation of diesel generator sets in Ladakh is procured by JKPDD in Ladakh at a cost of Rs. 46.34 per liter from the Indian Oil Corporation Depot in the town of Leh.

25 The capacity factor can be reduced further to $82 \%$ due to elevation of $11,800 \mathrm{ft}$, where combustion is reduced due to lower oxygen levels. 
Table 12. 900-kVA Generator $(720 \mathrm{~kW})^{26}$

\begin{tabular}{|l|l|l|l|l|}
\hline Particular & $\begin{array}{l}\text { Consumption per } \\
\text { Hour }\end{array}$ & $\begin{array}{l}\text { Consumption per } \\
\text { Year }\end{array}$ & $\begin{array}{l}\text { Cost per Unit } \\
\text { (Rs.) }\end{array}$ & $\begin{array}{l}\text { Amount Per Year } \\
\text { (Rs.) }\end{array}$ \\
\hline Diesel (HSD) & 135 liters & $1,166,400$ liters & 46.34 per liter & $54,050,976$ \\
\hline Mobil-Oil & & 2,700 liters & 145.00 per liter & 391,500 \\
\hline O\&M & & & & $4,100,000$ \\
\hline TOTAL & & & & $\mathbf{5 8 , 5 4 2 , 4 7 6}$ \\
\hline
\end{tabular}

Source: LREDA

The total $\mathrm{kWh}$ output of a $720-\mathrm{kW}$ system is $5,676,480$, assuming a $90 \%$ capacity factor. The total cost of power is therefore approximately Rs. $10.3 / \mathrm{kWh}$ (US $\$ 0.20 / \mathrm{kWh}$ at an exchange rate of Rs. 50 for one USD). When the cost of installation and commissioning is added, the cost is approximately Rs. 12/kWh.

Given the challenging topography of Leh District, the government must also spend large sums of money on diesel transportation. Tankers capable of transporting diesel in 10,000-, 8,000-, and 5,000-liter capacities do so at an average cost of Rs. 5.28 per liter. When these costs are factored in, the $\mathrm{kWh}$ cost of power is even higher.

Leh District does not receive a special subsidy on the purchase of diesel. The Ministry of Petroleum and Natural Gas (MPNG) does provide a subsidy on diesel, but none on the cost of power produced from diesel generators. However, there is a small subsidy given for the bulk purchase of diesel for operating generators, at a cost of Rs. 1 per liter, inclusive of the excise duties in the state of Jammu and Kashmir. This does not have a significant impact on the cost of power to the user.

\subsubsection{Hydro}

The cost of hydropower is dependent on the capacity of the project in question. The cost of the 45-MW Nimoo-Basgo hydro project is estimated at Rs. 8.1 billion (US\$162 million). ${ }^{27}$ The hydro plant will likely produce 284.15 million $\mathrm{kWh}$ of electricity per year, assuming it is operational at full capacity seven months of the year and at one-third capacity for five months during the winter. The generation tariff (bus-bar at site) is estimated at Rs. 5.80/kWh, however, the cost to users is expected to be around Rs. 3 to Rs. 4 per unit (kWh) after subsidies from the government for the consumer. The cost of mini hydro is more than large hydro.

26 Cost 900-kVA diesel generator: installation and commissioning - approximately Rs. 11,520,000

${ }^{27}$ http://ladak.free.fr/news/html/2006/06hydro5.htm 


\section{Challenges}

\subsection{Overview}

There are many challenges involved in the implementation of solar minigrids in India, at each phase of the project deployment process. An assessment of the macro-environment elements, including political, economic, environmental, social, and technological (PEEST) factors, can yield factors that may impact India's energy development initiatives. A quick overview of these challenges by phase is presented in the PEEST analysis in Table 13 below. A path forward to remove barriers and enable solar minigrid development is also described on the following pages.

Table 13. PEEST Factors

\begin{tabular}{|c|c|c|c|}
\hline $\begin{array}{l}\text { PEEST } \\
\text { FACTORS }\end{array}$ & Phase 1: Project Planning & Phase 2: Implementation & $\begin{array}{l}\text { Phase 3: Operations \& } \\
\text { Maintenance }\end{array}$ \\
\hline Political & $\begin{array}{l}\text { - Clarity on gov't politics } \\
\text { - Land acquisition process } \\
\text { and ownership } \\
\text { - Procurement process } \\
\text { (transparent) } \\
\text { - Cooperative societies role } \\
\text { - Nodal agency role }\end{array}$ & $\begin{array}{l}\text { - Institutional readiness } \\
\text { - Reliable power } \\
\text { - Safety inspection }\end{array}$ & $\begin{array}{l}\text { - Uniformity of design } \\
\text { - Who maintains after } 15 \\
\text { years } \\
\text { - Project evaluation } \\
\text { - Penalties }\end{array}$ \\
\hline Economic & $\begin{array}{l}\text { - Funding process } \\
\text { - Financially viable - DPRs } \\
\text { - Off-take agreement } \\
\text { - Consumer subsidies } \\
\text { - Cost to user over time }\end{array}$ & $\begin{array}{l}\text { - Local employment impacts } \\
\text { - Theft of power }\end{array}$ & \\
\hline Environmental & $\begin{array}{l}\text { - Project locations - } \\
\text { identification process (land } \\
\text { banks) } \\
\text { - Permitting process } \\
\text { - Water allocation effects } \\
\text { - Accurate solar data } \\
\text { - Varying resource profiles } \\
\text { (solar, biomass, and hydro) }\end{array}$ & - Disturbed habitat & $\begin{array}{l}\text { - Monitoring of effects to } \\
\text { environment } \\
\text { - Water churpon system } \\
\text { monitoring }\end{array}$ \\
\hline
\end{tabular}




\begin{tabular}{|c|c|c|c|}
\hline Social & $\begin{array}{l}\text { - Consumer buy-in process } \\
\text { - Consumer education } \\
\text { - Role of and trust in } \\
\text { cooperative societies and } \\
\text { nodal organizations } \\
\text { - Level of social acceptance } \\
\text { of RE }\end{array}$ & $\begin{array}{l}\text { - Incentives for household use } \\
\text { - Economic impact on families } \\
\text { - Household energy use patterns } \\
\text { and behaviors } \\
\text { - Reliability/predictability of } \\
\text { energy impact on behavior }\end{array}$ & $\begin{array}{l}\text { - Consumer recourse } \\
\text { - Trust in institutions and } \\
\text { private sector } \\
\text { - Human capacity to adopt } \\
\text { - Workforce readiness } \\
\text { local employment and } \\
\text { training capacity }\end{array}$ \\
\hline Technological & $\begin{array}{l}\text { - Metering } \\
\text {-Which solar technologies } \\
\text { are prequalified? } \\
\text {-What about consumers } \\
\text { who are further than } 3 \mathrm{mi} \\
\text { radius? } \\
\text { - System must be modular } \\
\text { and flexible } \\
\text { - Role of hydro, geo, biomass }\end{array}$ & $\begin{array}{l}\text { - Unbalanced distribution systems } \\
\text { - Load sharing with adding } \\
\text { generator, hydro, solar, etc } \\
\text { - Integration with the grid } \\
\text { - Hybrid technologies }\end{array}$ & $\begin{array}{l}\text {-Training } \\
\text {-What happens as } \\
\text { demand increases? }\end{array}$ \\
\hline
\end{tabular}

Here, we present a high-level discussion on some of the most pressing challenges that merit further consideration. Some of the items below might already be addressed by MNRE under JNNSM; the information presented below is not meant to be policy recommendations for MNRE, but rather ideas that might require further analysis in the Indian context. More information will be needed to perform a more in-depth analysis for each of the challenges presented in the table above.

\subsection{Political}

It is important that national road maps, policies, and programs are seamlessly aligned to achieve meaningful levels of solar minigrid deployment in rural areas. An energy road map is most effective when combined with coordination and consistency from the institutional level to the regional and local levels. This will accelerate deployment of energy initiatives. Assistance or training may be needed from regional entities or other experts to increase local capacity to develop the necessary regulatory framework and programs to enact and implement the policy initiatives.

Uncertainties in the policy environment will slow down private sector investment at this nascent stage. It is the role of government to provide clarity on the different policies to which businesses must adhere and, in addition, to foster confidence among businesses that the policies will remain unchanged. 
Detailed below are some of the policy and regulatory areas that are known to enhance and provide more clarity and seamlessness to the process, along with incentives to stimulate the use of clean energy technologies in rural villages.

\subsubsection{Coordination and Assistance}

Coordination and assistance in the project development process is not always consistent across regions or among the national and local agencies. MNRE is currently using a centralized process to approve and facilitate projects. The role of the nodal agencies that facilitate renewable energy projects on a regional basis is unclear. Currently, local coordination with the block and villages is often required. In order to develop a project for a typical Indian village, the burden is currently on the private sector to get clearance for a project at various levels - from the gram panchayat, the block development officer for the district, to the local village head, or Sarpanch - for minigrid development.

As a result, many companies face problems obtaining clearances from local government bodies to acquire land or get transmission lines installed. Currently an NOC (No Objection Certificate) is needed for a private developer to start a project. To avoid such clearances, many companies have been installing small home lighting systems rather than common distribution systems. This may hamper the development of solar minigrids.

With the approval of MNRE, the nodal agencies in respective states could take responsibility for providing private developers with a streamlined process and local assistance throughout the implementation and operation phases. During the planning stages, the nodal agency would work with the villagers to help them understand the benefits of the system, facilitate local approval of land ownership, and secure the necessary approvals for minigrid implementation. Once the minigrid is operational, the nodal agency, in tandem with the local governing body, could monitor power theft and damaging of systems and provide appropriate deterrents. Having the nodal agency work with local officials could reduce the bureaucracy and fast-track the approval processes.

\subsubsection{RFP Process}

The current Request for Proposal (RFP) process is that the state nodal agency issues an RFP to solicit bids for projects. However, many of these RFPs might be created with limited stakeholder input. As a result, many companies that could respond to the RFP might be left out of the process, or may not respond to the RFP because the requirements are defined too narrowly. This may also affect how many bidders respond to RFPs. Involving stakeholders like developers, local authorities, and banks when framing the RFP, prior to rolling it out, could increase the number of responses. Another idea to consider is that RFPs can be led by financial institutions rather than the state agency. Banks would outline the system requirements and the financial conditions of the loan. This better ensures the bankability of the project and facilitates access to the financing resources that the banks can provide.

\subsubsection{Subsidies and Incentives}

Among the key areas that MNRE might consider are the subsidies and incentives provided to both the developer and the village end user for household lighting. With respect to the developer, the government currently provides a $90 \%$ capital equipment subsidy on large plants - this 
subsidy also applies to minigrid plants. However, minigrid plants require the capability to store energy in the form of batteries, which in the operational phase have a significant maintenance cost. A feed-in tariff (also known as a generation subsidy) ensures a level cost of energy over time and is used to decrease the cost to the end user while assisting the developers' recovery of investment and maintenance costs.

A feed-in tariff is a long-term price (tariff) that is set by the government for anyone who wants to feed renewable energy into the supply. It is the most common policy for encouraging renewable energy systems, in part because a feed-in tariff can achieve broader deployment at lower costs than other policy mechanisms, such as capital subsidies or direct incentives.

With feed-in tariffs, utilities are required to allow grid access and pay the set government price to anyone who can produce renewable power. The price, or tariff, is set so that a modest profit is ensured, thereby unleashing the collective capital resources of the entire province, state, or country to be part of the transition to renewable energy.

Feed-in tariffs reward actual production, unlike capital subsidies, which encourage installation but not necessarily operation. Because no bidding process is required, risk to developers is minimized and deployment of systems is accelerated as a result. Also, because these tariffs provide long-term contracts with utilities, they facilitate access to financing and encourage small and medium developers to participate alongside larger developers. Feed-in tariffs may also encourage community and local ownership and engagement, while also providing a potential source of revenue for these communities.

More than 20 countries in the world currently use a feed-in tariff model. Germany is considered to be one of the most successful in using feed-in tariffs to rapidly transition toward renewable energy systems. Using feed-in tariffs, Germany currently generates $12.5 \%$ of its electricity from renewable sources, while employing more than 215,000 people in the renewable energy sector, according to the German Federal Ministry of Economics and Technology.

Tariff rates encourage renewable power producers to use the most efficient technology, driving down costs by fostering industrial competition. Although overall electricity prices may rise slightly in the short term, in the longer term they stabilize as prices become increasingly independent of conventional fuel costs.

In like economies, it has been shown that having both capital and generation subsidies is very effective. Using both types of subsidies not only provides incentives for initial launch of a project, but also a better guarantee of success over time.

With respect to consumers, current government programs provide subsidies for kerosene and also distribute solar products for free, which can make users less inclined to purchase these products at cost. Broadening the current subsidy for kerosene to provide a subsidy based on lighting would enable consumers to choose their own lighting source (minigrid, bulbs, hydro, or standalone solar systems) while stimulating innovations related to solar microgrid and other 
clean technologies and business models. Subsidies can also be shifted from traditional fuels for electricity to renewable fuels to encourage a behavior change in the end user.

Deployment of solar minigrids might also benefit greatly from transmission and distribution subsidies that are currently covered under RGGVY for rural electrification.

Additionally, providing subsidies for the best technologies available and encouraging joint ventures to enable technology transfer might have a positive impact on the growth of minigrids in India.

\subsection{Economic}

Financing measures and renewable energy deployment in remote villages is a particular challenge for developers. Isolation from urban economies, relatively small populations and economies, and the expense of implementing clean energy systems without economies of scale make return on investment difficult.

\subsubsection{Project Financing}

Currently, debt financing for renewable projects in rural areas is not easily available, which means projects cannot obtain long-term funding. One of the main reasons for lack of funding is the uncertainty surrounding the return on investment or "bankability" of the project. Currently, under JNNSM, there are no off-take agreements that guarantee that the power produced will be purchased by end users. Villagers may continue to turn to alternate fuels, such as kerosene, if there are no incentives to purchase from a minigrid. As mentioned previously, there are no generation subsidies to ensure a levelized cost of energy over time and a return on investment. Clean technologies such as batteries and storage may not receive subsidies, which drives up the cost for both the developer and the end user. As a result, banks are unwilling to provide debt financing if future returns look uncertain or costs are not recoverable under a certain timeframe.

\subsubsection{Spurring Economic Development}

Access to energy spurs economic development, specifically by increasing agricultural productivity and educational opportunities and accelerating development of village enterprises. While many understand these benefits in theory, providing qualitative and quantitative evidence of such benefits can inform the policy-making process and allow energy service providers to develop short-term and long-term plans for how to grow capacity and address infrastructure concerns so they keep up with demand growth.

Understanding how to grow energy demand can also increase the rate of return for both developers and financial lenders. As one might hypothesize, energy growth in regions where there is currently none might be rapid and grow at an exponential pace and then plateau after a period of 10 years. Analyzing the following in recently electrified villages can help address this gap:

- Determine whether there are energy shortages and how the energy service provider has addressed growth in energy demand.

- Map out different stages of growth over the years and factors within each stage that have a direct impact on energy demand. More specifically, seek to determine factors/behaviors 
that can increase the usage of energy (and by how much) in rural villages and thereby more quickly spur economic growth.

- Determine which incentives work best for human behavior changes. For example, implementing policies that foster assistance for home-grown entrepreneurs in villages can help grow the customer base and provide a steady income stream for solar project developers and investors.

- Establish types of implementation practices that could better facilitate mingrid usage and ultimately the long-term success of village electrification.

\subsection{Environmental}

While some data for regions in India may exist, there does not appear to be readily accessible and bankable renewable energy resource data available, either for specific villages or on a regional level. Having resource data facilitates the identification of potential projects and attracts participation from interested developers and financers.

\subsubsection{Quality of Solar Resource Data}

Currently, there is satellite data available on all the regions in India, but there is a lack of ground data that validates actual resource data - a discrepancy that could lead to project underperformance. MNRE has installed 50 ground stations in India, and NREL is currently tasked with verifying the satellite data with the ground data, so some of these issues are already being addressed. To build minigrids throughout rural India, additional ground stations may be needed. A detailed regional resource assessment would provide the data needed to better understand the level of various resource availability and locations and the amount of renewable power generation potential for those locations. The quality of renewable resource assessment data can dramatically impact the participation of renewable energy project developers and banks.

\subsubsection{Project Identification and Land Acquisition}

Facilitating project identification with information on electrification needs within a state is important. This will help developers understand where they should locate projects. MNRE might consider developing land banks that identify lands for renewable energy development. In this way, MNRE can develop a pipeline of projects that developers can pursue. This can be communicated broadly by MNRE and nodal agencies to developers, and interested villages can then solicit interest from private developers.

In rural villages, the process for obtaining the land needed for project development is unclear. In some instances, the villages provide the land needed for development at no cost to the developer. Greater uniformity in the land acquisition process will reduce uncertainties for the developer.

Addressing each of these areas will help reduce the risk of project underperformance and costs associated with renewable energy deployment. We discuss this idea further in Section 6, Recommendations and Path Forward.

\subsection{Social}

Deployment of renewable energy is not solely a technical matter. Institutional, cultural, economic, and policy issues all play a significant role in the success of any project. DOE and 
NREL have accumulated significant experience in these "human" dimensions of energy deployment. Lessons learned from these experiences are vital and can support a coherent approach to supporting communities in a transition to higher levels of renewable energy.

Transformational change in anything, including the energy system and energy use, requires close collaboration of local stakeholders. Stakeholders in this effort might include the local government, schools and educational institutions, local businesses, fuel suppliers, finance partners, and residents of the rural communities. Developing a common vision is critical to determining a path forward and creating actionable goals. Collaboration ensures that all stakeholders have an opportunity to share their motivations, concerns, and ideas for changing a community's approach to energy generation and consumption. For example, the Hawaii Clean Energy Initiative (HCEI) has established topical working groups to provide broad representation as well as long-term vision and continuity to planning efforts. Implementing significant changes in energy systems and energy use and realizing the benefits of those changes takes time. This requires a collective vision with measurable goals and a stepped timeline for implementation, as well as coordinated government policy, planning, and budgetary support.

\subsubsection{Rural Village Peer Working Groups}

In parallel with efforts to produce high-quality, bankable resource assessments for regions, rural village working groups could be initiated to organize and aggregate grid data across the villages. Such research could be the development characteristics that facilitate the "bundling" of multiple villages, in close proximity to each other, into attractive project financing efforts.

Human capital development is essential for long-term success of petroleum reduction efforts. Village working groups could be implemented to share knowledge and deepen collaboration between rural village leaders. These peer groups would serve several important purposes, including:

- Developing a common understanding of grid, resource, load, and institutional characteristics

- Generating appropriate training and educational resources for village peers that share grid characteristics

- Coordinating and harmonizing energy road map efforts at the local level in support of economies of scale

- Presenting a unified body that can serve as the official point of contact for project developers and financiers.

For example, a group of villages that share certain characteristics, or are in close proximity to each other, will represent a potential opportunity to "bundle" development and project finance for renewable energy, transmission and distribution, or even generator upgrades. Various gridrelated factors that differ among rural villages are of particular importance, as they may frustrate efforts to reduce cost. If certain minigrid system specifications were widely shared across rural Indian villages - for example, system frequency, transmission line voltage, and distribution system phase and voltage - renewable energy interconnection standards might be harmonized, and bulk purchasing of equipment, training, and insurance might be feasible. 
Combining villages could facilitate brokerage of project development and may elevate project sizes sufficiently such that sophisticated project development and finance mechanisms could be deployed to reduce costs and improve project terms for village communities.

\subsubsection{Social Acceptance of Renewable Energy Technologies}

Impressions about renewable energy systems and their performance will play a role in local acceptance of development plans. Involving community stakeholders throughout the planning process will help the understanding of the full process development scope and timeline. In many cases, renewable energy projects have failed due to improper selection of technology for a particular application, faulty installation of the system or components, or inadequate maintenance. In the case of rural India, substandard material has been provided for home lighting systems, resulting in system issues, and this can create negative publicity and leave the impression that a particular technology does not work for rural Indian villages,

Social acceptance can also be an issue in the case of PV farms or wind turbines being located in previously undisturbed areas, or near culturally significant sites. Community outreach and involvement early in clean energy planning is essential for communicating potential impacts and benefits as well as understanding and mitigating concerns and obtaining local buy-in. This is where involving the diverse stakeholders in the planning of energy system road maps and in the RFP development process will be helpful and serve to mitigate concerns early in the planning process rather than later when they could impede the development and implementation of the plant.

\subsubsection{Training and Workforce Development}

Many renewable energy systems have performed poorly or failed due to lack of local experience and inadequate maintenance. Proper installation and maintenance is critical to keeping plants operational in remote village locations, since villagers will become more reliant on power for daily tasks as they adopt the new system. While maintenance concerns present a challenge when introducing new technologies to remote locations, they also present an opportunity for technical innovation and workforce training and development.

Although in many cases, expertise in implementing and maintaining renewable energy systems must come from outside rural villages, this presents an opportunity to develop training programs to create jobs for local installers and maintenance technicians. Where conditions allow, workforce development training is a significant boost to the local economy. These training programs are often partnerships involving the trades (e.g., electricians, plumbers, and HVAC installers), local colleges or trade schools, regional training organizations, and project developers.

Workforce training requirements for wind and solar PV energy can be significant but are not out of reach for most Indians. Increasingly, training programs from Europe, the United States, Australia, and other countries are available through online distance learning or can be offered through local community, vocational, or university systems. With the right incentives, such organizations may take advantage of local commercial and human resources to the extent possible. 


\subsubsection{Project Management}

The development of renewable energy projects is challenged by the relatively low level of understanding within the power sector and policy-making communities, both of which add risk to project development. For both power sector professionals and policy makers, an in-depth understanding of the project development process will be required if Indian regions hope to attract qualified project developers and financiers. The relatively small nature of most rural villages also means that supporting organizations may need to go further in the development of projects than what would be typical for projects in countries with more developed and larger markets. These challenges may combine to make it difficult for developers to execute successful clean energy projects at the most advantageous price. Support before and during the predevelopment and development process will greatly assist the execution of many energy projects and will serve to lower the risk (and cost) of subsequent projects.

Through work with many international communities, NREL has developed a number of models for managing project design and implementation. These models are useful in helping communities new to change management understand the change process. For example, in the U.S. Virgin Islands working groups were set up to address the various aspects of achieving the territory's goal of a $60 \%$ reduction in fossil fuel usage by 2025 . These working groups are contributing to the community energy planning process. And this model is helping other island communities meet their energy goals.

\subsubsection{Prevalent Business Models}

There are a number of business models that can work well in a community setting and can provide a good comparison to what is being employed under JNNSM across India. The Alliance for Rural Electrification recently released a white paper entitled Hybrid Mini-grids for Rural Electrification: Lessons Learned. The study compares several successful cases, including the following models:

1. Community-based model where the renewable energy system is owned and operated by the local community

2. Private sector-based model where the system or many of the components of the system are owned by a private entity

3. Utility-based model where the utility owns and operates the system

4. Hybrid model in which there is a combination of community, private, and utility ownership

The private sector-based model or the multi-party model may be better suited for rural Indian villages. Because the community model requires funds for the capital costs and knowledge to implement and operate the minigrid system, it would be difficult for a village community to attempt on its own.

However, in the private sector and multi-party models, the capital cost may be covered entirely by the private entity or shared among several parties.

Table 14 is an overview of each model and their respective strengths and weaknesses. 
Table 14. Overview of Business Models

\begin{tabular}{|c|c|c|c|}
\hline Business Model & Advantages & Disadvantages & Case Study \\
\hline $\begin{array}{l}\text { Community-based: } \\
\text { community owns and } \\
\text { operates system }\end{array}$ & 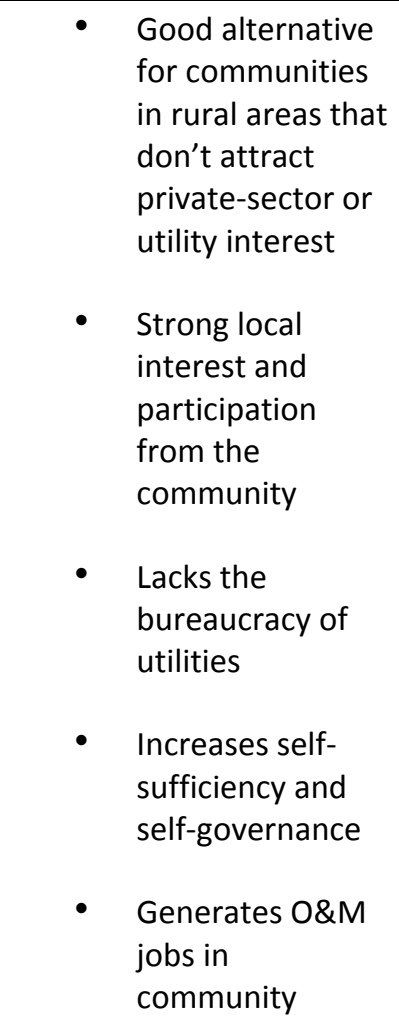 & $\begin{array}{l}\text { - } \quad \begin{array}{l}\text { Lack of local } \\
\text { expertise to } \\
\text { design, install, } \\
\text { and maintain } \\
\text { systems and } \\
\text { develop tariff } \\
\text { plans }\end{array} \\
\text { - Lack financing } \\
\text { resources } \\
\text { Potential for } \\
\text { social conflicts } \\
\text { such as } \\
\text { corruption }\end{array}$ & $\begin{array}{l}\text { Akkan, Morocco } \\
\text { Padre Coche, Peru }\end{array}$ \\
\hline $\begin{array}{l}\text { Private sector-based: } \\
\text { some or all system } \\
\text { components owned by a } \\
\text { private entity }\end{array}$ & $\begin{array}{l}\text { - } \begin{array}{l}\text { Usually the most } \\
\text { efficient model } \\
\text { for providing } \\
\text { electricity }\end{array} \\
\text { - Companies are } \\
\text { able to ensure } \\
\text { long-term O\&M } \\
\text { and have } \\
\text { technical ability } \\
\text { to address } \\
\text { problems } \\
\text { Often better than } \\
\text { public entities at } \\
\text { navigating } \\
\text { political } \\
\text { interference }\end{array}$ & $\begin{array}{l}\text { - } \begin{array}{l}\text { Public financial } \\
\text { support often } \\
\text { required }\end{array} \\
\text { Lack of interest } \\
\text { from private } \\
\text { companies to bid } \\
\text { on rural } \\
\text { electrification } \\
\text { concessions } \\
\text { Projects most } \\
\text { likely to be } \\
\text { carried out by } \\
\text { small local } \\
\text { companies, } \\
\text { which have } \\
\text { limited technical } \\
\text { and financial } \\
\text { resources }\end{array}$ & Philippines NPC SPUG \\
\hline
\end{tabular}




\begin{tabular}{|c|c|c|c|}
\hline $\begin{array}{l}\text { Utility-based: utility owns } \\
\text { and operates system }\end{array}$ & $\begin{array}{l}\text { - Strong } \\
\text { experience, } \\
\text { financial, and } \\
\text { technical } \\
\text { capabilities to } \\
\text { manage and } \\
\text { implement } \\
\text { project } \\
\text { - Good access to } \\
\text { financing } \\
\text { mechanisms } \\
\text { Ability to offer } \\
\text { extensive O\&M } \\
\text { services }\end{array}$ & $\begin{array}{l}\text { - } \begin{array}{l}\text { Low-revenue } \\
\text { minigrids not a } \\
\text { priority for many } \\
\text { utilities }\end{array} \\
\text { - High O\&M costs } \\
\text { - Potentially } \\
\text { unresponsive to } \\
\text { community } \\
\text { needs, resulting } \\
\text { in unwillingness } \\
\text { to pay } \\
\text { Driven by } \\
\text { political agendas }\end{array}$ & Joshua Tree NP \\
\hline Hybrid & Varies based on model & Varies based on model & $\begin{array}{l}\text { Sunlabob; San Juanico, } \\
\text { Mexico; Isla Tac, Chile }\end{array}$ \\
\hline
\end{tabular}

Source: Adapted from the Alliance for Rural Electrification's Hybrid Mini-Grids for Rural Electrification: Lessons Learned

Tables 15 to 19 in the Appendix present case studies from various countries that have implemented rural electrification models. Cases from Morocco, Peru, and Laos most closely resemble the rural Indian village environment and may be considered a best practice example to follow. These case studies are small rural villages with a mix of solar, hydro, diesel, and battery technologies. Financing and ownership arrangements are diverse, but in the case of Peru, the cautionary note is that the tariff structure did not adequately cover the cost of operating the plant.

\subsection{Technological}

Technology assessment and analysis provide a baseline for which technologies have been tested sufficiently and are considered commercially viable. Investing in a supplier prequalification process can provide more clarity on which technologies should be used for solar development, which MNRE has implemented through qualifying "channel partners." Also, once a project has been implemented, there needs to be a consumer recourse process if the project is not operational, not reliable, or malfunctioning. The nodal agency could potentially be the coordinating agency for monitoring performance and for any disputes arising with either the developer or end users. MNRE has addressed parts of this, but further investigation is required on best practices.

Smart-metering is another area that needs attention in small rural villages. There is currently an initiative in India to roll out smart meters to millions of households. This is driven by the need to optimize electrical usage, manage loads, mitigate operating inefficiencies, and help consumers 
and businesses understand their own electrical usage. In tandem with the rollout of solar minigrids, a coordinated effort could be made to meter all homes and enterprises attached to the minigrid. This not only allows monitoring of current usages, but also better enables the developer to predict energy patterns and trends, so power can be added to existing systems as village needs grow.

Currently, minigrids could face issues if there is a lack of adequate energy storage facilities. When renewable power sources get connected to the grid, the fluctuations in power generation may become a problem for grid stability. A solar array's output fluctuates not just between day and night, but between sunny and cloudy. So, having a reliable back-up to balance power loads during lag times is crucial for growing renewable energy in the grid.

Load profiles, which vary widely between villages, also strongly influence the feasibility of various balancing options to accommodate high penetrations of variable renewable energy. There are several issues with interconnecting hydro generation and solar generation to the electric grid that need to be addressed. These are discussed in more detail in Section 3.

Taking a power systems approach by integrating new sources of renewable energy along with end-user efficiency measures and grid modernization could help in the development of efficient minigrid infrastructures. Furthermore, given the sheer number of villages that need electrification, it is important to develop a more standardized turnkey approach in order to quickly build generation across all the villages. Developing a few pilot projects in a few geographically distinct regions within India can help achieve this outcome. 


\section{Recommendations and Path Forward}

Renewable technologies such as solar minigrids have the potential to greatly support the development of rural communities across India and around the world. The technical analysis shows that a solar minigrid solution, after considering government incentives, can yield solid returns for the investor and provide villages with inexpensive, reliable electricity.

There are several key recommendations from this report that will catalyze private sector involvement and warrant further research and consideration.

\subsection{Resource Identification-Land Banks}

To address the full potential of developing renewable energy projects, it is important to create land banks so developers know the location of the land available for development of renewable energy projects. The financial and transaction costs for individual companies to embark on this identification process can be significant. Land banks will further mobilize the private sector and assist in the development of a pipeline of projects, which can then be grouped and competed with greater ease.

Specific aspects of this exercise might include:

- Working with MNRE and nodal agencies to identify villages and regions that would be suitable for minigrid development

- Gathering data on the energy demand and load variances in each region

- Developing a land bank for identifying land that is available for renewable energy development

Creating a database of project locations would add significantly to the current information gap and provide another crucial piece of data to jump-start the market.

\subsection{Streamlining and Standardizing the Project Development Process}

The policy and institutional environment in which the private sector operates to develop and implement projects is as important as understanding where to locate projects. Ensuring proper checks and balances within any system will help create an environment that facilitates delivery of electricity in a reliable, cost-effective, and safe manner. Specifically, the following should be investigated further:

- Defining the process for engagement with private sector (i.e., via formal prequalification process)

- Streamlining solar minigrid processes so they are followed by everyone, with closer nodal agency involvement with all villages 
- Developing detailed project reports (DPRs) and RFPs: DPRs need be created in a manner that speaks to the bankability or commercial viability of the project, which is important for support from financial institutions

- Project identification and planning and coordination between and among regional/nodal agencies and villages

○ Land identification, acquisition, and procurement

- Undertaking a more regional approach, so villages are clustered and can take advantage of economies of scale

○ Project development and implementation

- Postconstruction O\&M

- Environmental permitting and socioeconomic impact assessment

Developing the above guidelines will help answer key questions, such as:

- What are the requirements for system design vis-à-vis enabling future integration with the primary grid, where applicable?

- What is the customer recourse if electricity is not provided or the solar project is not operational?

- Who is responsible for postconstruction O\&M, and what are the penalties for not maintaining the system?

- How are metering and billing conducted, and who monitors these?

- What is the mechanism for contracting for demand for power in rural areas, especially as power use increases over time?

- What are the environmental permitting requirements and socioeconomic impact of minigrids on the local population?

\subsection{Ensuring Project Bankability}

As mentioned previously, financing for minigrid projects may be difficult to obtain for a number of reasons.

Currently, under JNNSM, there are no off-take agreements that guarantee that the power produced will be purchased by end users. Villagers may continue to turn to alternate fuels, such as kerosene, if there are no incentives to purchase from a minigrid. Furthermore, there are no generation subsidies to ensure a levelized cost of energy over time and a return on investment. A feed-in tariff (also known as a generation subsidy) ensures a level cost of energy over time and is used to decrease the cost to the end user while assisting the developers' recovery of investment and maintenance costs. Banks are generally unwilling to provide debt financing if future returns look uncertain. Additionally, policies that foster assistance for home-grown entrepreneurs in villages can help grow the customer base and provide a steady income stream for solar project developers and investors. 
Policies that promote the energy solution provider as a priority lending sector for Indian banks would facilitate debt financing for renewable energy projects and reduce some of the uncertainty. If targeted finance vehicles could be developed for technology deployment and financing, a regional economy of scale may be created that could potentially reduce implementation costs, improve deployment strategies and penetration, and methodically reduce petroleum and kerosene use on a regional basis. This could be done in accordance with the lending guidelines of the Reserve Bank of India.

Depending on renewable resource similarities for various locations, a bundled technology deployment approach could be developed along with the financing vehicle that might encapsulate multiple villages into a single minigrid project and guarantee off-take customers for the electricity. A bundled approach would also decrease project implementation and operation costs, as they would be spread out over several villages. These activities could be coordinated with regional data collection and streamlined project development processes to increase effectiveness.

\subsection{Developing a Turnkey Systems Approach}

To accelerate the development of minigrids across Indian villages, it is important to develop a turnkey systems approach to implementing projects. Developing various projects in geographically distinct regions of India can help develop the standardized approach that can catalyze minigrid development.

As India works toward reduction in fossil-fuel dependency, closing the gap in these priority areas will support overall success. Through regional collaborations to build human capacity and technical expertise, many of the issues that make it difficult to expand the use of renewable technologies can be addressed, bringing concrete, long-term benefits to Indian citizens. 


\section{Appendix: Current Business Models}

Table 15. Community-Owned Hybrid Model

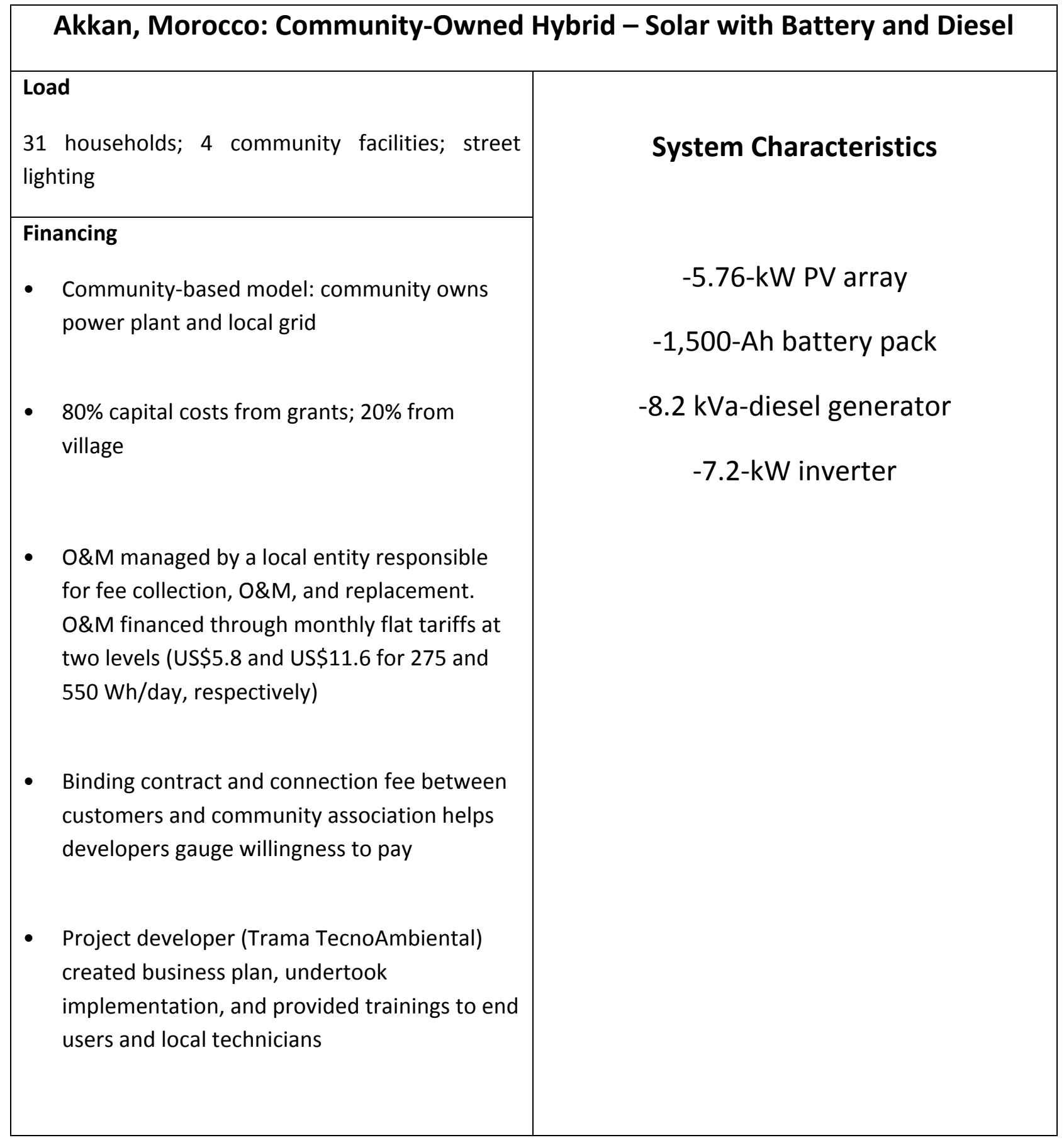


Table 16. Community-Administered Model

\begin{tabular}{|c|c|}
\hline \multicolumn{2}{|c|}{$\begin{array}{c}\text { Padre Cocha, Peru: Community-Administered Hybrid - Solar with Batteries and } \\
\text { Diesel Generator }\end{array}$} \\
\hline $\begin{array}{l}\text { Load } \\
331 \text { households; public street lighting }\end{array}$ & System Characteristics \\
\hline $\begin{array}{l}\text { Financing } \\
\text { - Capital costs financed through donations from } \\
\text { International Lead and Zinc Research } \\
\text { Organization, the Common Fund for } \\
\text { Commodities, Sandia National Laboratories, } \\
\text { and Loreta Regional Gov't. } \\
\text { - Local organization administers the system, } \\
\text { performs O\&M } \\
\text { Two tariff structures have been applied; } \\
\text { neither successful in recouping O\&M costs } \\
\text { - Lessons learned: tariffs need to recover O\&M } \\
\text { costs to be viable but should also be within } \\
\text { the range customers are willing to pay }\end{array}$ & $\begin{array}{l}-28-k W \text { PV array } \\
-240 \text { batteries of } 375 \mathrm{Ah} \\
-128-\mathrm{kW} \text { diesel generator } \\
-40-\mathrm{kW} \text { inverter and charger } \\
\text {-Distribution grid }\end{array}$ \\
\hline $\begin{array}{l}\text { Capital Cost } \\
\$ 577,000 \text { (\$2M with administration, promotion, } \\
\text { and studies) }\end{array}$ & $\begin{array}{l}\text { Rate Structures } \\
\text { Flat monthly charge: } \$ 6.38 \\
\text { Fixed monthly charge: } \$ 1.47 \\
\text { Usage charge: } \$ 0.20 / \mathrm{kWh}\end{array}$ \\
\hline
\end{tabular}


Table 17. Multi-Party-Owned Model

\begin{tabular}{|c|c|c|}
\hline \multicolumn{3}{|c|}{$\begin{array}{c}\text { Isla Tac, Chile: Multi-Party-Owned with PPA Hybrid Wind, Battery, Diesel } \\
\text { Generator }\end{array}$} \\
\hline $\begin{array}{l}\text { Load } \\
1 \text { health station, } 1 \text { school, } 82 \text { households }\end{array}$ & \multicolumn{2}{|c|}{ System Characteristics } \\
\hline \multirow{4}{*}{$\begin{array}{l}\text { Financing } \\
\text { - Capital cost supplied by National Fund for } \\
\text { Regional Development (48\%), U.S. DOE } \\
(12 \%) \text {, power distributor ( } 34 \%) \text {, and rural } \\
\text { community (6\%) as a pilot demonstration } \\
\text { project }\end{array}$} & Before & After \\
\hline & Candles & $\begin{array}{l}\text { 2x7.5-kW wind } \\
\text { turbines }\end{array}$ \\
\hline & Batteries & 100-kWh battery \\
\hline & Benzene generators & 12-kW diesel generator \\
\hline \multirow{2}{*}{$\begin{array}{l}\text { - O\&M: provided by power distributor } \\
\text { under a 10-yr power supply agreement }\end{array}$} & Paraffin & 13.5-kVA inverter \\
\hline & & $\begin{array}{l}\text { 18-km distribution } \\
\text { system }\end{array}$ \\
\hline $\begin{array}{l}\text { Capital Cost } \\
\$ 204,500\end{array}$ & $\begin{array}{l}\text { Rate Structure } \\
\text { Fixed monthly charge: } \$ \\
\text { Usage charge: } \$ 0.24 / \mathrm{kV}\end{array}$ & \\
\hline
\end{tabular}


Table 18. Private Utility-Owned Model

San Juanico, Baja California Sur: Private Utility-Owned Hybrid - PV, Wind, Battery Diesel Generator

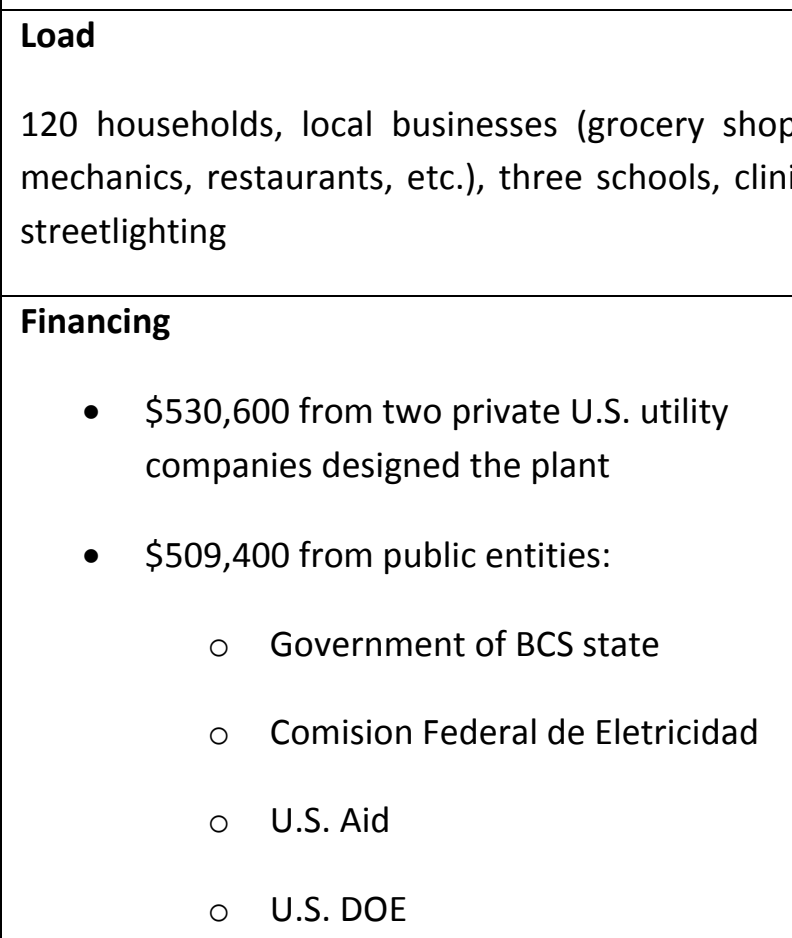

- Local community formed an electrification committee and designed tariff structure to cover O\&M

\section{Capital Cost}

$\$ 1,040,000$
System Characteristics

\begin{tabular}{|c|c|}
\hline \multicolumn{2}{|c|}{ System Characteristics } \\
\hline Before & After \\
\hline $\begin{array}{c}\text { 205-kW diesel } \\
\text { generator (supplied } \\
\text { power 3-4 hrs/day) }\end{array}$ & 17-kW PV array \\
\hline \multirow[t]{4}{*}{$\begin{array}{l}23 \text { homes equipped } \\
\text { with small gasoline- } \\
\text { powered generators }\end{array}$} & $\begin{array}{c}\text { Ten, } 7.5-\mathrm{kW} \text { wind } \\
\text { turbine }\end{array}$ \\
\hline & $\begin{array}{l}420 \mathrm{kWh} 240-\mathrm{VDC} \\
\text { battery (nominal } \\
2,450 \text { amp-hours) }\end{array}$ \\
\hline & $\begin{array}{l}\text { 120-kW diesel } \\
\text { generator }\end{array}$ \\
\hline & 90-kW inverter \\
\hline
\end{tabular}

\section{Rate Structure}

Residential use: \$5 fixed charge, plus

- First 50 kWh - $\$ 0.155 / k W h$ 


\begin{tabular}{|l|c|}
\hline & $\begin{array}{c}\bullet \quad \text { Next } 100 \mathrm{kWh}-\$ 0.185 / \mathrm{kWh} \\
\bullet \quad \text { Over } 150 \mathrm{kWh}-\$ 0.260 / \mathrm{kWh} \\
\text { Commercial use: } \$ 8 \text { fixed charge, plus } \\
\bullet \quad \text { All use }-\$ 0.270 / \mathrm{kWh}\end{array}$ \\
\hline
\end{tabular}


Table 19. Multi-Party-Owned Hybrid

\begin{tabular}{|c|c|}
\hline \multicolumn{2}{|c|}{ Laos: Multi-Party-Owned Hybrid - Solar, Hydro, Diesel Generator } \\
\hline $\begin{array}{l}\text { Load } \\
105 \text { households }\end{array}$ & System Characteristics \\
\hline $\begin{array}{l}\text { Financing } \\
\text { - } \quad \text { Public partners fund fixed assets (public } \\
\text { infrastructure and grid); Sunlabob finances } \\
\text { movable assets } \\
\text { - Sunlabob owns power generation system } \\
\text { and provides power and O\&M under a 25- } \\
\text { year PPA } \\
\text { - Charges a fee to each household based on } \\
\text { consumption } \\
\text { - Sunlabob internal rate of return: } 15 \% \\
\text { Vocal NGo liaises between village and } \\
\text { Sunlabob to maximize benefits for local } \\
\text { community } \\
\text { villagers employed by Sunlabob to operate } \\
\text { system and collect fees } \\
\end{array}$ & $\begin{array}{c}-12-k W \text { small hydro generator } \\
\text {-2-kW PV array } \\
-15-k V a \text { diesel generator }\end{array}$ \\
\hline
\end{tabular}

